\title{
PRESCHOOL FOR ALL: HOW SOURCING SHAPED NEWS FRAMING OF UNIVERSAL PRE-K ROLLOUT IN NEW YORK CITY
}

A Thesis
presented to
the Faculty of the Graduate School
at the University of Missouri-Columbia
In Partial Fulfillment
of the Requirements for the Degree
Master of Arts
bLLE MOXLEY
Amy Simons, Thesis Supervisor
DECEMBER 2017


The undersigned, appointed by the Dean of the Graduate School, have examined the thesis entitled

\section{PRESCHOOL FOR ALL: HOW SOURCING SHAPED NEWS FRAMING OF UNIVERSAL PRE-K ROLLOUT IN NEW YORK CITY}

Presented by Elle Moxley

A candidate for the degree of Master of Arts

And hereby certify that in their opinion it is worthy of acceptance.

Professor Amy Simons

Professor Elizabeth Brixey

Professor Ryan Famuliner

Professor Emily Crawford-Rossi 


\section{DEDICATION}

Jashin, you are my best friend, life partner, and Kingsley’s favorite lap. I hope you know how much I appreciate what you did for us while I was pounding this out. You cooked, you cleaned, you drove me to the hospital in the middle of the night - and you never complained, not once. I adore you.

As for Kingsley, it seems fitting that I started and ended graduate school with you curled at my feet. You were right there with me when my career took me from Columbia to Springfield to Independence to Bloomington to Kansas City - you complained constantly, and you've never thanked me for keeping you in you in kibble, not once. I will take you on a walk as soon as I finish this paragraph. Until then, go bug Jashin. 


\section{ACKNOWLEDGMENTS}

I'd like to thank KCUR Director of Content Strategy Donna Vestal, as I sincerely doubt I would have finished my graduate coursework without her encouragement. Then there's Maria Carter, my supervisor for the last three years - there's no way I could've written a thesis while working full time without her support. Maria is everything you want in a news director. Her judgment is excellent, her composure unrivaled, and she always knows when her reporters need a sheet of bubble wrap to pop to soothe their nerves. I also want to thank KCUR General Manager Nico Leone. When I left the job I loved covering Indiana schools to come home to Kansas City, he promised he'd get me back to the education beat someday. Nico, you're a man of your word. I'll consider the school board meetings I now sit through every other Wednesday your gift to me.

I owe Amy Simons a great deal of gratitude for stepping in as my advisor. You didn't have to take me or my thesis on, but you did, and I think that says so much about your commitment to train the next generation of journalists. To Liz Brixey, Ryan Famuliner, and Emily Crawford-Rossi, my other committee members, my deepest thanks.

I was so fortunate to continue my University of Missouri education at The Examiner, where fellow Tigers Sheila Davis, Jeff Fox, and Karl Zinke taught 22-year-old me everything journalism school doesn't prepare you for. One of the few professional regrets I have is not going to work for Scott Elliott, who was an incredible mentor to me in Indiana. Scott, analyzing the work of Chalkbeat reporters has made me a better journalist. Thank you for that. And finally, to Dan Margolies, my new editor - don't worry. This will be fun. 


\section{TABLE OF CONTENTS}

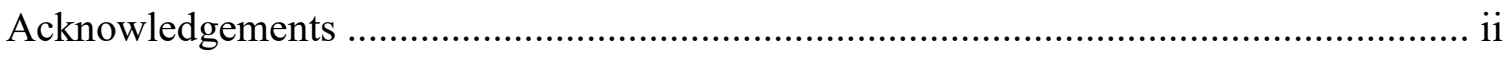

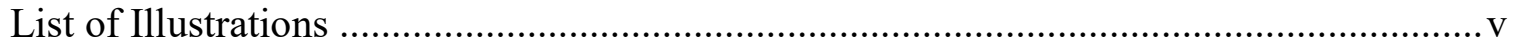

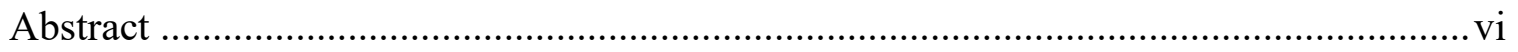

Chapter

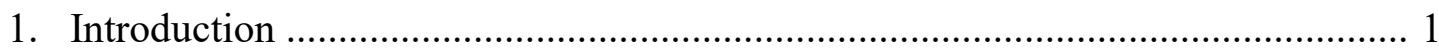

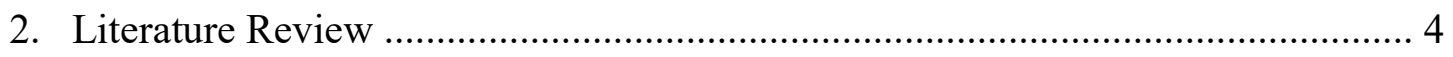

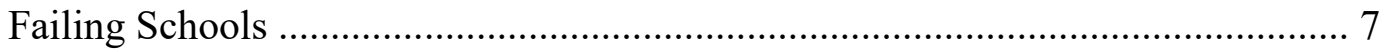

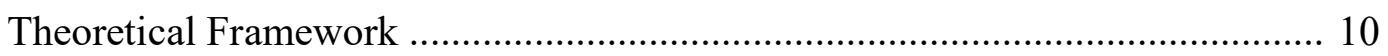

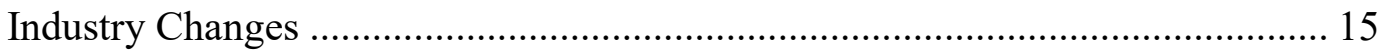

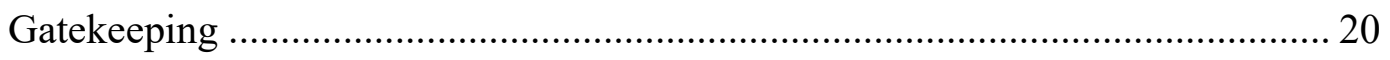

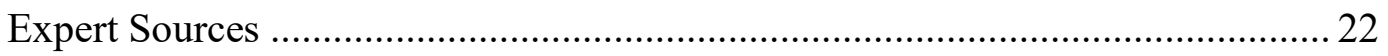

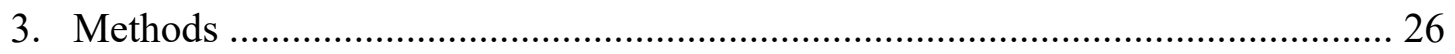

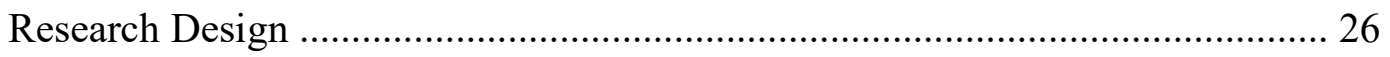

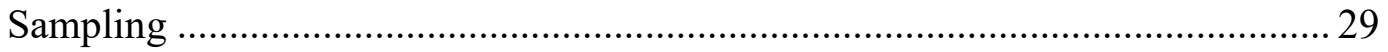

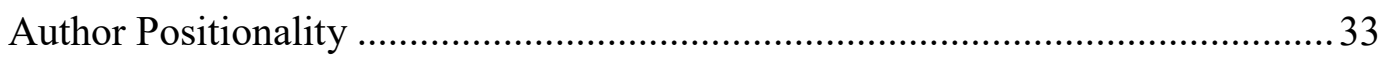

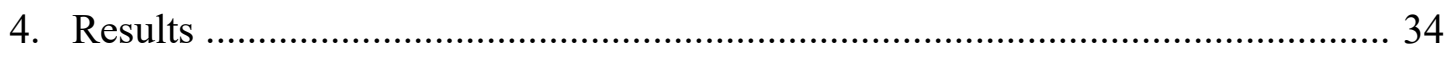

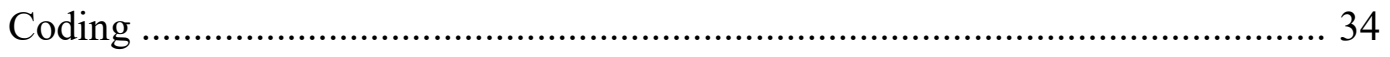

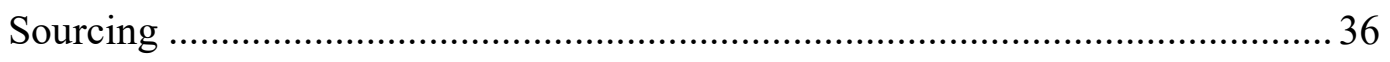

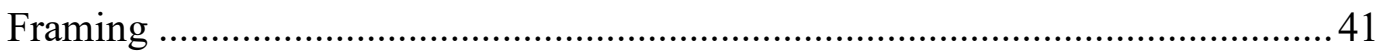

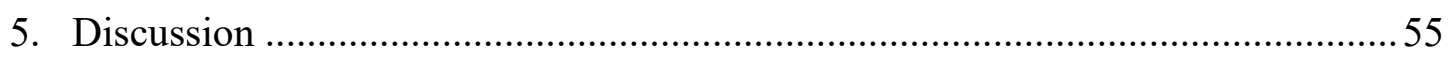

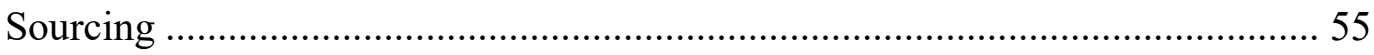




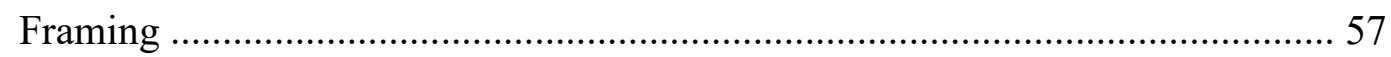

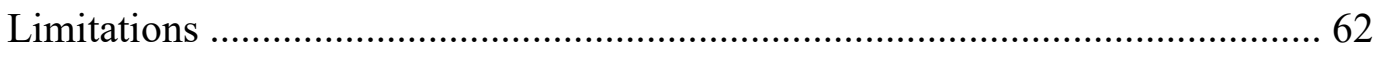

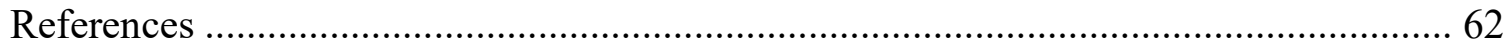

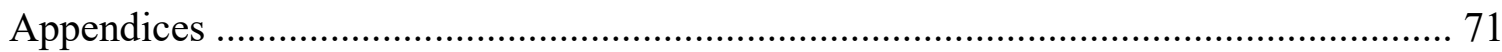

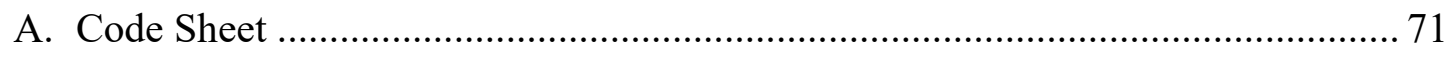

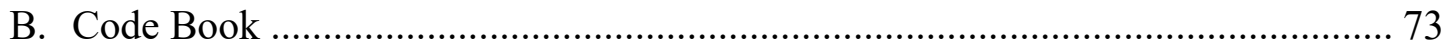

C. Chalkbeat New York Articles Collected for Analysis ..........................................75

D. New York Times Articles Collected for Analysis ................................................. 83

E. WNYC Articles Collected for Analysis ......................................................... 91

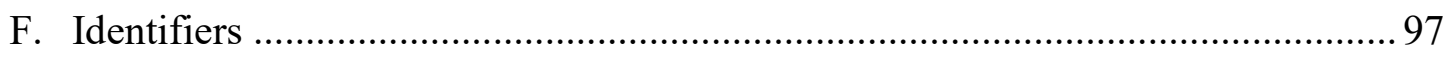

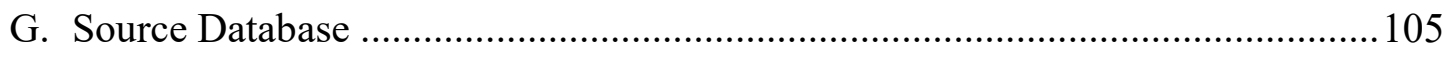

H. Frames by Media Type ……………………………................................ 127

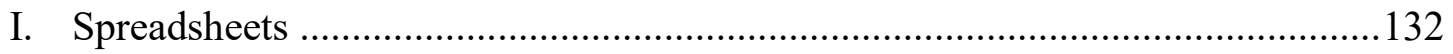




\section{LIST OF ILLUSTRATIONS}

\section{Figures}

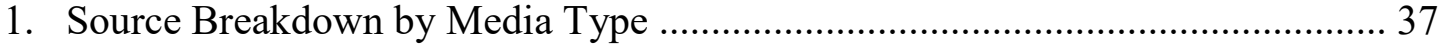

2. Generic News Frames by Media Type .......................................................... 43 


\title{
PRESCHOOL FOR ALL: HOW SOURCING SHAPED NEWS FRAMING OF UNIVERSAL PRE-K ROLLOUT IN NEW YORK CITY
}

\author{
Elle Moxley
}

Amy Simons, Thesis Supervisor

\begin{abstract}
As niche publications fill the void left by a shrinking legacy media, this comparative case study asks how the sourcing practices of journalists at the education news nonprofit Chalkbeat New York influenced news framing of early childhood education. Chalkbeat's coverage of universal pre-K rollout in New York City was compared to The New York Times and WNYC. A qualitative content analysis of 178 articles published between January 1 and December 31, 2014, found that journalists at all three news organizations quoted government sources most often. But Chalkbeat and WNYC also brought education officials into the conversation, something reporters at The New York Times did only occasionally. This might be because universal pre-K is framed as a political issue in The Times. As the Every Student Succeeds Act replaces the deeply unpopular mandates of No Child Left Behind, this comparative case study points to the need for education reporters who are subject matter experts capable of translating jargon and policy for their audience.
\end{abstract}




\section{Running head: NEWS FRAMING OF UNIVERSAL PRE-K ROLLOUT IN NYC Introduction}

I have the best job in the world. I cover Missouri schools and students for KCUR 89.3, the NPR affiliate in Kansas City. I'm happiest when I'm visiting pre-K classrooms. Preschoolers always have a million questions when a reporter visits. I let them try on my headphones and talk into my microphone while I explain why I'm there. I'm also a teacher's kid. Mom spent 36 years teaching art and English to middle and high school students. I didn't plan on becoming an education reporter, but I've come to care deeply about what's happening in my city's schools. I believe every child deserves a quality education, and I believe my job is to take our listeners into classrooms and explain the effect of policy on students and teachers.

Before coming to KCUR, I covered state education policy for NPR in Indiana. In 2012, Indiana schools were implementing the controversial education policies of thenGovernor Mitch Daniels and his Superintendent of Public Instruction, Tony Bennett. I spent a significant amount of time in rural K-12 schools documenting how A-F school grades, teacher evaluations, and an ever-changing state accountability system affected schools and students for StateImpact Indiana. Our fair, nuanced reporting earned us three national Edward R. Murrow awards from the Radio Television Digital News Association. More importantly, it earned us the respect of parents, teachers, and administrators. People in communities that no longer had a daily newspaper were just grateful that someone cared about what was happening in their schools. 


\section{NEWS FRAMING OF UNIVERSAL PRE-K ROLLOUT IN NYC}

I describe my beat as P-12, though not everyone considers preschool to be part of the public education system (Carr, n.d.). As recently as 2014, Indiana didn't provide any state funding for pre-K, not even for low-income students. I spent my mornings talking to researchers who were publishing studies about the benefits of preschool - and my afternoons listening to state lawmakers who claimed there was insufficient evidence that pre-K worked to justify funding it with taxpayer dollars. The education research that was out there was completely ignored by policymakers, which I found incredibly frustrating. Not only do I believe in education reporting that is backed by research, but also that journalists must talk to students, teachers, and parents, not just government or official sources. I feel an obligation to take listeners into schools so that they can hear from stakeholders how policy effects them.

Increasingly, education philanthropies are funding news coverage of schools. Many of these online-only news nonprofits promise to include more stakeholder voices in their coverage of schools. This comparative case study seeks to understand whether the sourcing practices of journalists at niche publications actually differ from those who work for legacy media through qualitative content analysis. As such, I will compare news coverage of the rollout of universal pre-K in New York City in 2014 from three media outlets with different funding structures - Chalkbeat New York, a niche education blog primarily funded by foundations; The New York Times, the newspaper of record; and WNYC, New York City’s flagship NPR station.

RQ1: How do the sourcing practices of journalists at niche news organizations differ from those who work for legacy media? 


\section{NEWS FRAMING OF UNIVERSAL PRE-K ROLLOUT IN NYC}

Next, I will examine how source selection influenced each news organization's framing of universal pre-K rollout. According to Cavazos, "Framing within stories about education tends to rely on institutional voices and can ignore important context, sometimes missing the nuances of issues as well” (2014, p. 15). In addition to identifying generic news frames present in each media outlet's coverage, I will also look for frames specific to universal pre-K.

RQ2: How did each news organization frame universal pre-K rollout in New York City?

Though it's likely universal pre-K will be framed as a campaign promise of New York Mayor Bill de Blasio, news coverage could just as easily be situated within a growing body of research into early learning. It's extremely critical that we understand how education policy is being reported as the Every Student Succeeds Act again changes the conversation we have about schools. 


\section{NEWS FRAMING OF UNIVERSAL PRE-K ROLLOUT IN NYC}

\section{Literature Review}

President Barack Obama used his 2013 State of the Union address to advocate for expanded access to early childhood education (Matthews, 2013). At the time, only a handful of states funded pre-kindergarten for all 4-year-olds. Although the president did not use the words "universal pre-K" in his speech, many news outlets reported it like he had (Rich, 2013). Consequently, many early childhood education advocates were disappointed a few days later when the White House announced it would invest $\$ 75$ billion in federally-funded Head Start program and state partnerships that guaranteed access only to low-income children (Matthews, 2013). In other words, what Obama was proposing wasn’t truly universal pre-K, according to an assessment by FactCheck.org. Writes Farley, "Interestingly, while Obama proposed preschool for all and talked about the burden of preschool costs on middle-class families, the details of the proposal unveiled by the White House ... suggest the federal focus is primarily on students from low-income families" (2013). Preschool for some, it turns out, doesn't have quite the same ring to it as preschool for all (Wong, 2014a).

It's true that most of what we know about the benefits of preschool come from small-scale programs that could hardly be described as universal (Farley, 2013). Since the first findings were published in 1981, the Perry Preschool Project has had an outsized influence on education policy (Heckman, Pinto, \& Savelyev, 2013). For three decades, researchers in Ypsilanti, Michigan, tracked the education and economic outcomes of black children from economically disadvantaged families who attended Perry Public 


\section{NEWS FRAMING OF UNIVERSAL PRE-K ROLLOUT IN NYC}

Schools in the 1960s. Half of the group received instruction from trained teachers for two years before they were to start school. This was before Head Start. The students who attended preschool as 3- and 4-year-olds were less likely to commit crimes as adults (Heckman, Pinto, \& Savelyev, 2013). They were less likely to smoke and had better health outcomes than their peers who did not attend preschool. They also made more money. Economists have calculated an unusually high return on investment for the Perry Preschool Project - as high as \$16 saved for every dollar spent (Mervis, 2011). But most school districts couldn't afford the upfront investment Perry made. The Chicago Longitudinal Study, which began in 1985, was designed to be a low-cost alternative to Perry and other pioneering preschool studies. Researchers found students who attended preschool at Child Parent Education Centers were better prepared to start kindergarten than those who had not. They were also less likely to need special education or enter the juvenile justice system (Mervis, 2011). The Chicago Longitudinal Study continues today. In 2007, the year participants turned 27, researched tabulated an 8-to-1 benefit-to-cost ratio.

Unfortunately for elected officials, the effects of the Perry Preschool Project have been almost impossible to replicate on a large scale. "As solid as these studies are, they can't provide policymakers with everything they need: a prescription for the best, most cost-effective intervention that can help the largest number of at-risk children," Mervis writes (2011, p. 952). Karoly (2016) points out another problem: the entity that pays for preschool doesn't always reap the benefit. A city that raises taxes to pay for preschool has no guarantee that those kids will stay in the community. The education department that 


\section{NEWS FRAMING OF UNIVERSAL PRE-K ROLLOUT IN NYC}

invests in 3- and 4-year-olds doesn't recoup that cost if fewer of them end up in prison as young adults (Karoly, 2016). As a result, 30 percent of 4-year-olds and 58 percent of 3year-olds in the United States were not enrolled at any preschool in 2015 (Phillips et al., 2017).

Head Start funding represents the federal government's largest investment in early childhood education. But the education outcomes for low-income children enrolled in Head Start have been mixed. The modest gains Head Start students make are usually lost by the end of the kindergarten year (Pianta, Barnett, Burchinal, \& Thornburg, 2009). There is evidence to suggest that Early Head Start - for children 3 and younger - can produce better outcomes. In fact, research has consistently shown that children who start preschool at 3 are better prepared than students who start at 4 (Heckman, Pinto, \& Savelyev, 2013; Mervis, 2011; Pianta, Barnett, Burchinal, \& Thornburg, 2009). Yet “ ... rarely do politicians who've declared early education a top priority say they want to expand access to preschool" (Wong, 2014b). Instead, policymakers tend to focus specifically on pre-K, the year before kids start school. Such was the case in New York City in 2013 when de Blasio campaigned on the promise of universal pre-K.

From the beginning, the way de Blasio talked about preschool access made some early learning advocates uncomfortable. De Blasio liked to say for less than the cost of a soy latte per day, the wealthiest New Yorkers could educate all of the city's 4-year-olds (Potter, 2014). But de Blasio “ ... emphasizes the flow of money from the wealthy to the poor, entrenching the idea that early childhood services are a boost to the needy rather than a common good" (Rothschild, 2014). Politicians frequently use economic 
NEWS FRAMING OF UNIVERSAL PRE-K ROLLOUT IN NYC

consequence frames to advocate for their preferred policies (Semetko \& Valkenburg, 2000). But by framing pre-K in terms of economic inequality, early learning advocates felt de Blasio missed an opportunity to build a broad coalition of support for public pre-K (Potter, 2014).

\section{Failing schools}

It's important to contextualize Obama's pre-K push against the fading legacy of the No Child Left Behind (NCLB) Act. In 2013, the U.S. Department of Education was granting waivers releasing states from the act's most onerous requirements. Education department officials tightly controlled messaging around student achievement during George W. Bush's presidency. At one point, the Department of Education paid a public relations firm $\$ 700,000$ to rate media coverage of NCLB. According to a department spokesman, the purpose was to "educate" reporters about school accountability (Lewis, 2004, p. 260). But the plan backfired. Journalists with low scores were wearing them like badges of honor, while journalists with high scores were apologizing to their colleagues. Even then-Secretary of Education Rod Paige was having trouble getting full marks from the PR firm he'd hired (Lewis, 2004). For example, getting an op-ed in the Seattle Times wasn't good enough - praise for Bush's signature education initiative needed to appear in a national publication. Democrats complained the Bush administration was trying to bully reporters into writing positive stories (Goldstein, 2011).

The pervasive negativity of schools coverage can be traced back to the 1983 "A Nation At Risk" report, which concluded American students were falling behind their peers in other countries (Ansary, 2007; Berliner \& Biddle, 1995; Briggs, 2012; Garland, 


\section{NEWS FRAMING OF UNIVERSAL PRE-K ROLLOUT IN NYC}

2014; McQuaid, 1989; Schneider, 2016; Watson, 1998). Before “A Nation At Risk” was

published, newspapers covered education as a local issue. In fact, when education

reporters were offered a sneak peek at the Education Writers Association (EWA) national

seminar in the spring of 1983 , most of them passed up the opportunity to interview a

national expert. The thinking at the time was they could just call up the president of the

local school board for comment once the report was published (McQuaid, 1989). Then

President Ronald Regan's National Commission on Excellence in Education published its

open letter to the American people. "If an unfriendly foreign power had attempted to

impose on America the mediocre educational performance that exists today,"

commissioners wrote, "we might well have viewed it as an act of war." Newspapers that

didn't have anyone covering education in 1983 sent inexperienced reporters who'd only

ever written obituaries into schools to determine if they were failing (McQuaid, 1989).

Reagan had succeeded in making failing schools a national crisis and education a

campaign issue.

But there was a problem. "The landmark document that still shapes our national debate on education was misquoted, misinterpreted, and often dead wrong," Ansary argues (2007). Longtime “A Nation At Risk” critics Berliner and Biddle recall a 1993 press conference summarizing a report on literacy the U.S. Department of Education had commissioned. The next day, The New York Times reported that half of all adults in the U.S. couldn't read. For weeks, newspapers carried “countless stories about the supposed illiteracy of the American public that were to be read by millions of people" (Berliner \& Biddle, 1995, p. 10). Ironically, it seems none of the reporters at the press conference 


\section{NEWS FRAMING OF UNIVERSAL PRE-K ROLLOUT IN NYC}

actually read the report. If they had, they would've realized "the researchers had classified people as 'illiterate' merely because they did not score well on a test of reading comprehension” (Berliner \& Biddle, 1995, p. 10). Reporters were just repeating what they had been told at the press conference: that illiteracy causes poverty, even though fully 40 percent of the supposed "illiterate" were employed full time. In fact, only 30 percent of those the researchers dubbed illiterate actually used the word "poor" to describe themselves. The study - like others before it - actually concluded that poverty causes illiteracy, which is a different problem with different policy implications. So either the Department of Education spokesman misspoke, or he intentionally misled reporters. Berliner and Biddle posit it was the latter, as what the spokesman said supported the popular narrative: American schools were failing. "No news analyst seems to have questioned the basic premise put forth by the Department of Education" Berliner and Biddle write (1995, p. 10).

"Failing public schools" has become a catchall term describing individual and systemic failures to achieve desired educational outcomes in the years since "A Nation At Risk” was published (Briggs, 2012, p. 2). Hogan (2013) found education reporters covering NCLB routinely used the following words to describe schools: failing, broken, ineffective, crisis, reform, overhaul, low-achieving, low-performing, underachieving, worst-performing, underperforming, troubled, problem, needs improvement, in need of improvement, falling behind, falling short, falling apart, struggling, and lagging behind. "Syntax such as 'schools ... landed' implies that schools actively put themselves in a position of failure," Hogan writes (2013, p. 29). Reporters used the term "failing" to 


\section{NEWS FRAMING OF UNIVERSAL PRE-K ROLLOUT IN NYC}

describe schools that did not make annual yearly progress toward achievement goals and also " ... as a keyword presumably understood by the audience” (Hogan, 2013, p. 62). This is what Entman (1993) refers to as word salience.

But scores on the National Assessment of Educational Progress - an achievement test colloquially known as "the nation's report card" - have actually improved in the last 40 years, with black and Hispanic students making some of the biggest gains (Schneider, 2016). And yet "A Nation At Risk" continues to influence education policy in this country. Many Obama-era education initiatives - the Common Core State Standards and teacher evaluations, to name two - were built on commissioners' suggestions that schools needed to raise standards and overhaul the teaching profession (Garland, 2014;

Schneider, 2016). "The excoriation of American schooling is what most people remember," writes Garland of the "A Nation At Risk" report, "but its actual legacy is ingrained in public education today" (2014). In other words, if Americans were not dissatisfied with their public schools, no one would be advocating for universal pre-K (Gormley, 2005).

\section{Theoretical Framework}

Goffman (1974) first advanced frame theory as a form of rhetorical analysis. He attempted to contextualize political communications by situating them within a field of meaning. According to Matthes (2009), the most frequently cited definition of frame analysis comes from Entman:

To frame is to select some aspects of a perceived reality and make them more salient in a communicating text, in such a way as to promote a particular problem definition, causal interpretation, moral evaluation, and/or treatment recommendation for the item described. (1993, p. 52) 


\section{NEWS FRAMING OF UNIVERSAL PRE-K ROLLOUT IN NYC}

Frames need not be explicit because journalists can count on their readers to fill in the gaps (Entman, 1993; Morasso, 2012). Writes Morasso:

To evoke a frame and its corresponding scenario it is not necessary to make every single term pertaining to this frame explicit; for example, saying 'You paid too much money for this old chair' is sufficient to activate the commercial frame and evoke our scenario or 'prototypical scene' of a bargain. (2012, p. 199)

As such, the absence of certain words or phrases will reinforce facts or judgments.

According to Hogan, communicators " ... make either conscious or unconscious decisions about what to say based on the schemata that organize their beliefs" (2013, p. 11). There is no guarantee a receiver will interpret a frame as the communicator intended, but the use of specific language can ensure messages will be processed and stored. Some terms become inextricably linked with the phenomenon that they describe. "Once a term is widely accepted," writes Entman, "to use another is to risk that target audiences will perceive the communicator as lacking credibility - or will even fail to understand what the communicator is talking about" (1993, p. 55). The example Entman gives is affirmative action, but for the purposes of this comparative case study, we could just as easily talk about failing schools. It is important to understand a frame is not a position for or against a policy measure (Gamson \& Modigliani, 1989). That is not to say certain terminology isn't polarizing. According to Brydie, "The use of language is so important when enforcing a frame that to not use your rhetoric is to use the other party's" $(2014, \mathrm{p}$. 1376).

Morasso examined contextual frames in newspaper coverage of Italian journalist Giuliana Sgrena's kidnapping, which she defines as "the background against which a 


\section{NEWS FRAMING OF UNIVERSAL PRE-K ROLLOUT IN NYC}

certain event is presented as a piece of news" (2012, p. 197). Sgrena, a pacifist, was on assignment in Baghdad in 2005 when she was captured and held for a month by insurgents before Italian intelligence officers could negotiate her release. While transporting Sgrena to the airport, Major General Nicola Calipari was killed by friendly fire (Morasso, 2012). Through in-depth analysis of news coverage produced in the two days after Sgrena's release, Morasso was able to document the emergence of two distinct news frames. The first frame Morasso identified interprets Calipari's death as an event. "In this frame, Sgrena's personal identity is not as important as her being a hostage who Calipari had a duty to protect" (Morasso, 2012, p. 204). Calipari's death becomes unfortunate but not unforeseen given his line of work. However, it is also possible to interpret Calipari's death as the result of an action, specifically the decision to negotiate for Sgrena's release. Morasso found newspapers were more likely to ask who was responsible for Calipari's death when it was framed as the result of an action.

According to Iyengar (1994), the standards of news production have given rise to episodic frames that blame individuals instead of society. Attribution of responsibility was the most common generic news frame Semetko and Valkenburg (2000) identified. After the oil tanker Exxon Valdez ran aground at Prince William Sound, Alaska, U.S. journalists asked if Captain Joseph Hazelwood had been drinking. The Guardian criticized this approach; it framed the disaster as a regulatory one not to be pinned on any one man (Jones, 2006). The U.S. media is especially concerned with the assignation of blame to individuals (Iyengar, 1987). Indeed, media outlets tend to ask if individual actors behaved as they should in times of crisis or disaster. Although this would seem to 


\section{NEWS FRAMING OF UNIVERSAL PRE-K ROLLOUT IN NYC}

contradict the professional norm of objectivity, journalists get around this by attributing potentially controversial material to sources. "A newspaper could, for example, use the views of an interest group to raise questions about sexually transmitted diseases. Such a story may contain moral messages or offer specific social prescriptions about how to behave" (Semetko \& Valkenburg, 2000, p. 95).

Sometimes it is obvious that journalists are seeking a particular point of view. At the annual conference of the National Union of Teachers in 1993, a reporter was overheard telling a photographer, "Get the sort of delegates that give our readers nightmares" (Baker, 1994, p. 289). When Kunelius (2006) conducted a series of in-depth interviews with Finnish newsmakers, nearly all of the politicians, professionals and businessmen " ... felt they were put into a position where they were largely expected to supply the necessary comments or play the role the storyline was in need of" $(2006, \mathrm{p}$. 677). Though no one Kunelius interviewed "used the fashionable communication research term," nearly all of the Finnish newsmakers reported being framed in an interaction with a journalist (2006, p. 677). One interviewee likened it to putting on a straitjacket, as he felt he had to perform to meet the reporter's expectations.

Of course, sources supply frames, too. It may be helpful to think of every story as the product of complex negotiations between journalists and sources, journalists and editors, and journalists and spokespersons (Peterson, 2001). To test the hypothesis that an increasingly critical news media created opposition to the Vietnam War, Hallin examined the sourcing practices of journalists over a 10-year period. Hallin found that journalists weren't doing their work much differently in 1973 than they had in 1963 . What changed 


\section{NEWS FRAMING OF UNIVERSAL PRE-K ROLLOUT IN NYC}

was how sources - not journalists - talked about the war as opposition moved from the fringes of society to the political mainstream.

A form of journalism which aims to provide the public with a neutral record of events and which, at the same time, relies primarily on government officials to describe and explain those events obviously has the potential to wind up as a mirror not of reality, but of the version of reality government officials would like to present to the public. (Hallin, 1984, p. 20)

Likewise, Entman (1993) found that in the run up to the Gulf War, there was tacit consensus among political elites that there were only two options: war now, or sanctions now with war later. Because no one with sufficient clout was talking about negotiation between Iraq and Kuwait, journalists did not report it as a serious possibility (Entman, 1993). Writes Entman, “Unpublicized, the views could gain few adherents and generate little perceived or actual effect on public opinion" (1993, p. 55).

Numerous researchers have documented journalists' tendency to rely on official sources for information (Baitinger, 2015; Boykoff, 2012; Cavazos, 2014; Hallin, 1984; Lacy \& Coulson, 2000; Kline \& Burstein, 2005; Kowalchuk, 2010; Kunelius, 2006; Moeller, 2006; Peterson, 2001; Walejko \& Ksiazek, 2010). According to Walejko and Ksiazek, "Over 30 years of sourcing studies show an abundance of research in a variety of traditional news media contents all providing the same result; government sources prevail in the news while civilian sources remain virtually speechless" (2010, p. 415). But very few sourcing studies have been conducted since the Great Recession of 2008, when researchers focused on the technological advancements and market forces driving change in the industry. Now that newsrooms have adjusted to their post-recession reality, it's 


\section{NEWS FRAMING OF UNIVERSAL PRE-K ROLLOUT IN NYC}

time to update the research on sourcing to reflect new media models that have emerged in the last ten years.

\section{Industry Changes}

New technologies have always disrupted old ones. In 1952, about a third of Americans got their political news from television and about a third from radio (Bennett \& Manheim, 2006). By 1964, three presidential campaign cycles later, 58 percent of Americans said they turned on the TV for political news. In just 12 years, the relative influence of radio had declined dramatically: less than 4 percent of Americans said it was their medium of choice for election coverage. Subsequent technological advancements promised to democratize communications, but that still hasn't happened:

The fact is that information, knowledge, and policymaking have gravitated increasingly toward a relatively elite class of experts and professionals. The mainstream media grew to power and influence and, by the late twentieth century, these media had emerged as truly the fourth branch of government, absolutely critical to the function of democracy.... But as the press gained this new and important role - even becoming in many situations the check and balance mechanism of first resort - it also continued to coalesce into a relatively closed loop of professionals who knew the ropes, understood the systems, and had the credentials. They could make their voices heard, but not always everyone's voices heard. (Kline \& Burstein, 2005, p. xiv-xv)

Except the Internet has so fundamentally altered reporters' routines that Klinenberg (2005) argues the sociological studies on which modern communications theory was built are no longer relevant to newsrooms today.

According to the Pew Research Center for the People and the Press, in 2015, 41,400 people worked as reporters or editors - down 4 percent from 2014 and 37 percent from 2004 (Barthel, 2017). It was the worst year for newspapers since the Great Depression and its immediate aftermath. At the same time, journalists are under 


\section{NEWS FRAMING OF UNIVERSAL PRE-K ROLLOUT IN NYC}

enormous pressure to do more with less, resulting in " ... a new system of stratification inside the newsroom, with elite reporters given ample time to do large projects and a large staff of second-tier journalists responsible for much of the daily workload" (Klinenberg, 2005, p. 56). Today, there are even fewer journalists on beats that weren't particularly well covered before the Great Recession of 2008, even as advertisers carve audiences into increasingly small slivers with the expectation that newsrooms will create content just for them (Bennett \& Manheim, 2006).

There is, however, some evidence lost newspaper jobs are being recouped elsewhere in the industry. In 2015, the most recent year for which data is available, the number of broadcasting and Internet publishing jobs surpassed the number of newspaper jobs (Shafer \& Tucker, 2017). According to data culled from the U.S. Bureau of Labor Statistics, there are now three times as many broadcasting and Internet publishing jobs as there were in 2006. Public broadcasters have always relied on a certain level of institutional support, but in the years since the Great Recession, NPR and PBS affiliates have been growing thanks in large part to readily available foundation funding. In a single year, foundation support for PBS NewsHour increased 15 percent - from 56 percent in 2014 to 71 percent in 2015 (Mitchell \& Holcomb, 2016). PBS is widely regarded as “America's largest classroom," carrying educational programming that helps prepare young children for school (Henson, 2017). But education coverage only accounts for about 1.4 percent of all broadcast news (Edmonds, Guskin, Rosentiel \& Mitchell, 2012). Significant investments from foundations may soon change that, as funders usually want to see more reporting on a particular beat. In 2011, NPR hired six reporters 


\section{NEWS FRAMING OF UNIVERSAL PRE-K ROLLOUT IN NYC}

to cover state education policy for member stations in Florida, Indiana and Ohio. ${ }^{1}$

Although NPR eventually scrapped its Impact of Government project, it continued to invest in education coverage with nearly $\$ 17$ million in grants from the John S. and James L. Knight Foundation, the Bill and Melinda Gates Foundation, the Wallace Foundation, and the Ford Foundation (Jensen, 2013).

Public broadcasters aren't the only ones seeking grant funding to pay for news reporting. Increasingly, foundations are funding work once paid for by advertisers and subscribers (Giles, 2010; Marcus, 2011). Nonprofits like ProPublica promise to "pick up where conventional media have left off' (Marcus, 2011, p. 16). According to Ferrucci, "This new type of journalism organization differentiates itself from traditional market models through its use of technology and its nonprofit status" (2015, p. 905). So it's not just how the news is reported that's changing - it's also who pays for it. Giles (2010) believes the newspaper of the future is a narrowly-focused online publication:

Circle of Blue is among several non profit news organizations testing one of the industry's most-discussed ideas: that serious journalism can be supported with funding from a variety of sources behind carefully constructed firewalls built on traditional standards of journalistic ethics. It is a prototype of a business model that supports specialized coverage, but it in fact embraces characteristics common among other start-ups and experiments that hold promise as a new way of paying for serious journalism. (p. 27)

Giles says it should come as no surprise that these niche news outlets have become popular. In fact, he believes the shift has been happening for decades. Just as Sports Illustrated and People "killed" The Saturday Evening Post, online news start-ups are

\footnotetext{
${ }^{1}$ The author worked for WFIU in Bloomington, Indiana as a StateImpact Indiana journalist between 2012 and 2014.
} 


\section{NEWS FRAMING OF UNIVERSAL PRE-K ROLLOUT IN NYC}

siphoning readers from institutional media outlets that can no longer fund specialized reporting (Giles, 2010).

Niche news nonprofits are growing in popularity. GothamSchools began in 2008 as a collaboration between blogger Philissa Cramer and teacher Kelly Vaughan. Funding came from the Open Planning Project, a nonprofit software developer that created tools for civic engagement. Its launch merited a two-paragraph blurb in Education Week. GothamSchools promised to not only provide the latest New York City school news, but also to keep "a critical eye on education research" (Jennings, 2008). Five years later, when GothamSchools merged with EdNews Colorado and rebranded itself as Chalkbeat, it was an education news network valued at \$2.2 million (Bhuiyan, 2014). Today, Chalkbeat has reporters in Colorado, Indiana, Michigan, New York, and Tennessee, with future plans to expand into other markets (Steussy, 2016).

Though Chalkbeat earns some revenue from a jobs board where educators can look for work, it relies primarily on philanthropic giving (Bhuiyan, 2014). National foundations - the Bill \& Melinda Gates Foundation, the Ford Foundation, and the Walton Family Foundation, to name a few - are both funding Chalkbeat's education coverage and lobbying for their preferred policies at the state and federal level (Steussy, 2016). That means Chalkbeat reporters inevitably cover the very organizations that fund their work. Still, Chalkbeat editors insist there is a firewall between the newsroom and big donors. According to Chalkbeat's "Core Values," "Our unique impact as journalists lies in our ability to tell the full and complete story, without consideration of profit, ideology, 


\section{NEWS FRAMING OF UNIVERSAL PRE-K ROLLOUT IN NYC}

or advocacy" (2017, para. 2). If Chalkbeat shows a bias, says Cramer, it's to policy wonks, the education experts whose research Chalkbeat promises to elevate.

But education policy is contentious, and not everyone agrees on who's an expert. In an interview with the Columbia Journalism Review, Leonie Haimson, the founder of the nonprofit Class Size Matters, said of Chalkbeat, "One of the weaknesses that I've seen ... is that there are certain sources that they go to repeatedly, and others that they leave out. They're less good at searching out grassroots groups and parents" (Steussy, 2016, para. 20). Arthur Goldstein, a teacher-blogger who advocates for public education, isn't as charitable. "I am consistently amazed at what Chalkbeat regards as expert advice. Evidently, if you have enough cash to start an astroturf group, or if Bill Gates gives it to you, that's good enough for them" (Goldstein, 2016). Goldstein's beef? A story on graduation rates that quoted a report from StudentsFirstNY - the pro-reform political lobbying group Michelle Rhee started after stepping down as chancellor of Washington, D.C., public schools - but no teachers. "Though there are tens of thousands of teachers," Goldstein writes, "though said teachers have a union, Chalkbeat New York could not be bothered asking them" (2016).

Educators have long argued that StudentsFirstNY and other reform-oriented groups are anti-union, and their complaints aren't without merit. Goldstein (2011) found that teacher unions were only referred to positively in 4.5 percent of the articles she analyzed. They were portrayed negatively 54.4 percent of the time, more frequently even than they were portrayed neutrally (41.1 percent). Young teachers were portrayed as more effective than older educators belonging to a union, while Rhee was portrayed as 


\section{NEWS FRAMING OF UNIVERSAL PRE-K ROLLOUT IN NYC}

having style and substance (Goldstein, 2011). "Rhee could do something no one has done before: she could prove that low-income urban kids could catch up with kids in the suburbs," writes Amanda Ripley for Time. "The radicalism of this idea cannot be overstated" (Goldstein, 2011, p. 561). Goldstein found that both Time and The New York Times framed teacher unions as anti-reform. Building on Goldstein's research, Shine (2015) found major newspapers generally portrayed teachers as opposed to standardized tests while voicing support for such exams on their editorial pages.

Increasingly, educators are pushing back against the narrative that schools are failing. "Every reporter or editor who has ever been responsible for the education beat," writes Aleta Watson, assistant city editor for the San Jose Mercury News, "has received 'the Call.' On the other end of the line is a principal, teacher or parent" complaining that all schools coverage is negative (1998, p. 729). “Don't you think it's time you printed something good?" In the five years I've been reporting on education, first in Indiana and now in Missouri, I've gotten the call Watson describes dozens of times. Usually the person on the other end of the line wants to pitch a feel-good story. Sometimes, the pitch comes with an implicit threat: if I don't cover the story, my access to schools could be in jeopardy.

\section{Gatekeeping}

Gatekeeping is a communications theory closely associated with frame analysis that involves the filtering of information before dissemination (Tandoc \& Peters, 2015). Education reporters have long complained that potentially controversial information isn't made available to them and that they must rely on some sort of public information officer 


\section{NEWS FRAMING OF UNIVERSAL PRE-K ROLLOUT IN NYC}

for access to schools (Jacobson, 1973). Cavazos (2014) posits that a lack of student and teacher voices in education coverage might be due to a lack of access. To audit journalists' access to schools, Berkenbile (2009) contacted nine principals in the same Oklahoma school district under the auspices of doing a story on cafeteria food. The messages she left with four principals indicated the story she was writing would be positive; the other five indicated the story would be negative. None of the positive stories required an escalation of the request to the central office, but three of the negative stories did (Berkenbile, 2009). The researcher was denied access to one school because she wasn't writing a positive story. In another instance, Berkenbile actually had permission to go into the school at lunchtime, only to be bodily stopped by a security guard who refused to confirm her visit with the principal. Interestingly, Berkenbile found schools that served predominately low-income students to be more welcoming than schools that drew from affluent neighborhoods.

Berkenbile acknowledges that journalists who have an established relationship with the school district probably have an easier time securing access than an unknown researcher, and my own experience suggests she is right. When I first started covering education for KCUR, I couldn't get anyone at Kansas City Public Schools to call me back. But once district officials got used to seeing me at school board meetings, they started responding to my media requests. I'm still not allowed unfettered access to schools, though. A principal or the district spokeswoman must accompany me at all times. When EWA asked its members to rate access to the schools they covered, 76 percent of respondents agreed with the statement, "The public is not getting all the 


\section{NEWS FRAMING OF UNIVERSAL PRE-K ROLLOUT IN NYC}

information it needs because of barriers schools, institutions or departments are imposing on journalists' reporting practices" (Carlson \& Roy, 2014, p. 5). Every education reporter must recognize the typical school visit is carefully choreographed. "Reporters need to understand the political landscape well enough to detect when school initiatives are launched more for political rather than educational ends," writes Carr in EWA's “Standards \& Ethics" guide (2013, p. 2).

Consider what happened in Arizona in 2000. Voters overwhelmingly approved the Proposition 203 "English for the Children" initiative to teach only English in schools, even though a vast body of research supports bilingual education (Moses, 2007). Wright (2005) argues that the well-funded proponents of Proposition 203 purposefully misrepresented what goes on in a bilingual classroom. Although the target was clearly Spanish-speaking English language learners, Arizona education officials also shut down a Navajo Immersion program, even though native students in it were doing better than peers in an English-only program. Wright wrights, "Illusions of rationality were created through the use of misleading statistics and other numbers and sound bites. Flawed academic research was used to justify decisions already made” (p. 690, 2005).

\section{Expert Sources}

Haas (2007) is concerned about the proliferation of think tanks that purport to do education research. Between 2001-2002, the most referenced think tanks were the American Enterprise Institute, the Cato Institute, the Economic Policy Institute, the Family Research Council, the Heritage Foundation, the Manhattan Institute, and the RAND Corporation (Haas, 2007). Haas coded the language journalists used to describe 


\section{NEWS FRAMING OF UNIVERSAL PRE-K ROLLOUT IN NYC}

the think tanks for a subset of 591 news articles. In Haas' opinion, journalists did not provide enough information about each think tank. For example, calling the Heritage Foundation a "conservative group" might help readers place it on the political spectrum, but it says very little about its staffers' qualifications to speak on a particular topic. "Readers would not know from this news piece that Krista Kafer has only a B.A. in history and no experience in education policy analysis beyond her work at the Heritage Foundation" (Haas, 2007, p. 84). Haas found that journalists took think tanks at "face value" and presented them as credible sources of information (2007, p. 77). Just 10 of the 591 articles contained criticism of a think tank. News outlets considered to be liberal were just as likely to rely on think tank research as conservative ones, Haas found.

Koger, Masket, and Noel (2009) provide an interesting lens through which to view the special interest groups that dominate the education landscape. They posit that special interest groups are actually a competing form of political organization with the potential to disrupt the party system, and researchers can learn a great deal about the scope and influence of political parties by examining their relationships and the media:

A threshold question is whether some interest groups and media groups cooperate primarily with the Democratic party while others tend to work with the Republican party. If all groups - or at least moderate groups - trade freely across the network, then we may conclude that most interest groups and media outlets are free agents who deal with both sides. (Koger, Masket, \& Noel, 2009, p. 643)

The researchers wanted to establish which candidates and causes were sharing donation lists with each other. By donating a small amount of money to one political organization, the authors were then able to track what other political organizations solicited them. The researchers also subscribed to a number of newspapers, magazines and periodicals. Then, 


\section{NEWS FRAMING OF UNIVERSAL PRE-K ROLLOUT IN NYC}

they mapped the connections to see if they could link up ideologically dissimilar groups. Though the researchers were unable to find a through line between Democrat and Republican groups, they established that even nominally independent media outlets can have these political connections (Koger, Masket, \& Noel, 2009).

Klaidman and Beauchamp (1987) compare the relationship a journalist has with a regular source to that of fiduciary agent and client: they are cordial, even friendly, to one another. They may eventually become close. "But there are crucial differences. One of a fiduciary agent's main goals is to serve the interests of clients, whereas a journalist's main goal is to provide the public with information" (Klaidman \& Beauchamp, 1987, p. 219). And while in an ideal world the press would never be manipulated, politicians, bureaucrats, law enforcement, lawyers, trade associations, and other regular sources mislead reporters as a matter of course. Tamir and Davidson (2011) argue that education policy is particularly susceptible to influence by political elites who know how to manipulate the media.

That's a problem because journalists confer legitimacy to the sources they choose to interview (Wheeler, 2008). If one reporter talks to someone, so will everyone else. "A regular theme in journalism literature," writes Lewenstein, "is the frequency with which journalists, whose cultural values include a commitment to independence and inquiry, follow each other around to the same stories" (1987, p. 31). Lewenstein found this "pack mentality" to be especially prevalent among reporters who cover niche topics. According to Lacy and Coulson, "Beats create a 'bureaucratically constructed universe' ... use of sources from organizations associated with a reporter's beat makes the sources' 


\section{NEWS FRAMING OF UNIVERSAL PRE-K ROLLOUT IN NYC}

organizations seem more legitimate to the audience and often leads to exclusion of less popular ideas" (2000, p. 14).

Former U.S. Senator Charles Robb might've said it best when he said, "Research is necessarily lengthy and contemplative, and does not easily lend itself to discussion. This is just the formula for making the eyes of journalists and policymakers glaze over" (Mcnergney, 1990, p. 22). But Michele S. Moses, an education researcher who's written extensively about race and affirmative action, argues that education researchers have a responsibility to make themselves available to journalists. She urges her colleagues to stop making dismissive statements about education coverage in its current state. "There is nothing wrong with presenting stories that are of human interest; in fact, these are often the most engaging stories," Moses writes (2007, p. 155). To her point, education research doesn't have to be dull or boring - it can tell compelling stories. For too long, education researchers have submitted their papers to scholarly journals and expected someone else to do the hard work of alerting journalists and policymakers of important findings (Moses, 2007). The journalist-source relationship requires reciprocity - if researchers want reporters to cover the publication of reports and key findings, then they must make themselves available to comment on other stories, too. Reporters on deadline have to talk to someone, and if a reputable education researcher won't agree to an interview, a less knowledgeable source with an agenda probably will. 


\section{NEWS FRAMING OF UNIVERSAL PRE-K ROLLOUT IN NYC}

\section{Methods}

Yin (2014) has argued case study should be considered a distinct method with its own research design. Yin defines case study as "an empirical inquiry that investigates a contemporary phenomenon (the 'case') in depth and within its real-world context" (2014, p. 16). According to Yin, case study is useful for answering research questions that ask how or why. A comparative case study examines two or more separate instances of a certain phenomenon (Yin, 2014). "The comparative case approach uses an iterative analysis of each case with final comparison of emergent themes and explanations. The results of each analysis are not pooled, as the strategy is that of multiple experiments, not multiple sampling" (Campbell, 2010, p. 175). Comparison is a useful tool because it highlights differences that might not have been conceptualized in a single case approach (Hallin \& Mancini, 2004). Comparative analysis can also prevent researchers from falling into the trap of thinking their results are universal (Hallin \& Mancini, 2004; Yin, 2014).

\section{Research Design}

The sourcing practices of education reporters have not been studied extensively, but those of other niche journalists - especially those who cover climate science - have been (Coulson, 2001; Jones, 2006; Walejko \& Ksiazek, 2010; Boykoff, 2012; MolekKozakowska, 2017). My research design is modeled after Boykoff's analysis of news coverage of the 2010 United Nations Climate Change Conference. Boykoff searched the Lexis-Nexis and ProQuest databases for references to "global warming" or "climate change" in four major newspapers and on five U.S. television networks during the 


\section{NEWS FRAMING OF UNIVERSAL PRE-K ROLLOUT IN NYC}

Cancun summit. Sources were qualitatively coded and subsequently divvied into such categories as "foreign government leader" or "U.S. national political actor" (Boykoff, 2012, p. 256). Nearly half - 45 percent - of the sources journalists turned to Boykoff classified as "transnational political actors" - conference organizers, U.S. politicians, foreign leaders and local government officials (2012, p. 255). Another 22 percent were representatives of nongovernmental organizations supplying information and commentary. Environmentalists were interviewed infrequently. Writes Boykoff:

The tendency to turn to authority figures - or, "official sources"- for their political opinions is a deeply ingrained facet of news coverage as is the related tendency toward indexing; media coverage is bracketed - or indexed - according to the range of views and policies found within the corridors of institutional power. $(2012$, p. 252)

Although journalists have, over time, reframed climate change as an economic issue rather than an environmental one, few sought the expertise of economists, who made up just 1.6 percent of the sources who appeared in major U.S. newspapers or on major U.S. television networks (Boykoff, 2012). Boykoff argues a much better frame for the reporting of climate change would be as a national security issue.

Some of the niche education news nonprofits that have come online in recent years have promised to include the perspectives of students, parents, and teachers who are most affected by policymaking.

RQ1: How do the sourcing practices of journalists at niche news organizations differ from those who work for legacy media? 


\section{NEWS FRAMING OF UNIVERSAL PRE-K ROLLOUT IN NYC}

New York City is one of a handful of media markets sustaining an editoriallyindependent education blog. ${ }^{2}$ Chalkbeat New York started covering public education in the city in 2008 as GothamSchools. I wanted to compare Chalkbeat's coverage to two legacy news organizations - a daily newspaper and a public radio station.

There are, of course, many daily newspapers that cover New York City - Daily News, New York Post, and Newsday, to name several. However, I went with The New York Times because it had the largest circulation and an easy-to-access archive. I was already reading the national edition, so it seemed only natural. Whereas Chalkbeat's journalism is primarily funded by foundations, The New York Times generated nearly $\$ 1.6$ billion in revenue in 2014 through a combination of advertising and circulation. Print advertising brought in $\$ 480$ million that year, while digital advertising brought in \$182 million (Malik, 2017). The Times added approximately 150,000 digital subscribers in 2014, bringing the total to nearly a million.

WNYC, New York City's largest public radio station with 1.7 million weekly listeners, has a funding structure much more similar to Chalkbeat ("New York Public Radio Media Kit,” 2017). For the fiscal year that began July 1, 2014, WNYC reported \$57 million in contributions and grants to the Internal Revenue Service ("New York Public Radio Annual Report FY14,” 2014). That year, WNYC received funding from the Corporation for Public Broadcasting to report on education issues in New York City, though the emphasis was on high dropout rates, not universal pre-K ("CPB Awards

\footnotetext{
${ }^{2}$ Other media markets include Colorado, Indiana, Michigan, and Tennessee, though the news nonprofits in these cities are less established than Chalkbeat New York. This, along with my own interest in early childhood education, led to the selection of universal pre-K in New York City as the research topic.
} 


\section{NEWS FRAMING OF UNIVERSAL PRE-K ROLLOUT IN NYC}

Grants," 2014). Although radio is a form of legacy media, WNYC fundraises to pay for education coverage, a model that mirrors Chalkbeat's. As such, WNYC was also included to provide a point of comparison between Chalkbeat and The New York Times.

Most inquiries into journalists' sourcing practices since the Vietnam War have been quantitative in nature (Baitinger, 2015; Hallin, 1984; Kowalchuk, 2010; Vercellotti \& Brewer, 2006). However, quantitative research is not necessarily better for frame analysis. According to Entman:

Often coders simply tote up all messages they judge as positive and negative and draw conclusions about the dominant meanings. They neglect to measure the salience of elements in the text, and fail to gauge the relationships of the most salient clusters of messages - the frames - to the audience's schemata. Unguided by a framing paradigm, content analysis may often yield data that misrepresent the media messages that most audience members are actually picking up. (1993, p. 57)

Recent analyses of newspaper framing of NCLB have been quantitative (Hogan, 2013:

Cavazos, 2014). But we know qualitative content analysis can help describe a phenomenon when existing research is incomplete (Hseih \& Shannon, 2005).

RQ2: How did each news organization frame universal pre-K rollout in New York City?

Thanks to Hogan (2013), we know that all five generic news frames identified by Semetko and Valkenburg - conflict, human interest, economic consequences, morality, and attribution of responsibility - are present in education coverage. Here also I will identify any issue-specific frames that emerge over the course of my analysis.

\section{Sampling}

To determine the feasibility, I first pulled articles for a small pilot study. Because de Blasio campaigned on a promise of universal pre-K, I constrained my searches to the 


\section{NEWS FRAMING OF UNIVERSAL PRE-K ROLLOUT IN NYC}

first month of his term. Between January 1, 2014, and January 31, 2014, Chalkbeat New York published 13 articles on pre-K; The New York Times, 15; and WNYC, nine. A code sheet (see appendix A) was filled out for every source that appeared in a WNYC story in January 2014. To be assigned an identifier, a source had to be quoted, not just mentioned. Biographical information, such as title, affiliation, and political party, was recorded. The code book (see appendix B) instructs the coder to place each source into one of the following categories: New York City official, state official (including elected representatives), New York City Department of Education official, teachers union, academic/institutionally-affiliated researcher, think tank, advocacy organization, principal/administrator, classroom teacher, parent, student, or other. These categories are similar to the ones Boykoff (2012) used in his analysis of news coverage of the Cancun climate summit. I added to the code sheet the questions Semetko and Valkenburg (2000) asked to determine the five generic news frames, and examples of each to the code book. I also added to the code book instructions to mark evocative language that could be useful in qualitative analysis, such as the words associated with the failing schools frame (Hogan, 2013).

WNYC quoted 25 non-unique sources in nine stories about pre-K in January. Some sources, such as de Blasio, appeared over and over in the coverage. A different identifier was assigned for each article in which de Blasio appeared. Occasionally, a quote would be attributed to an organization rather than an individual. In those cases, the name of the organization was listed as the affiliation. An unknown spokeswoman for de Blasio, for instance, was entered as being affiliated with the mayor's office. I considered 


\section{NEWS FRAMING OF UNIVERSAL PRE-K ROLLOUT IN NYC}

noting whenever a quote came from a news release; however, this information wasn't consistently provided. I decided it made sense to pull all articles about pre-K from the three outlets published in calendar year 2014, a time period that would encompass implementation and enrollment, as well as the first semester of the 2014-15 school year. A description of how articles from each news organization were sampled follow.

Chalkbeat New York. The merged GothamSchools and EdNews Colorado launched the Chalkbeat website in January 2014 (Bhuiyan, 2014). It has not been redesigned in the years since. The website allows searches constrained by bureau and date range. Articles from the New York bureau tagged with the keyword "pre-K" were pulled first. Morning news roundups - a daily collection of links to other reporting under the heading "Rise \& Shine" - were excluded from the search results. Between January 1 and December 31, 2014, Chalkbeat New York published 66 articles with the pre-K tag. A second search, for "preschool," collected four more articles. Seventy articles from Chalkbeat New York were collected for preliminary analysis (see appendix C). Two articles were later discarded because they were not actually about pre-K; a "Rise \& Shine" morning news roundup pulled in error was also omitted for a total of 67 articles.

The New York Times. The last major overhaul of nytimes.com was in January 2014. At that time, the website was "replatformed" so its look and feel could be updated without migrating archival material to a new content management system (Greenfield, 2014). A decision was made to only search for results within "NY/Region." This was done for two reasons: to exclude opinion, and to exclude national reporting not specifically about pre-K implementation in New York. The first search for "pre-K" 


\section{NEWS FRAMING OF UNIVERSAL PRE-K ROLLOUT IN NYC}

within the prescribed date range yielded 67 results. Some results - the full text of Mayor de Blasio's inaugural address would be one example - were immediately excluded because they were not bylined articles. Searching for "preschool" found eight results that pre-K did not, including six articles about allegations of sexual abuse at a preschool. These were included in the initial sampling after a quick skim suggested the article would question whether the system of policies and procedures was adequate to protect other children enrolled in other preschools across the city. I also felt it might be of interest because Chalkbeat did not cover issues tangentially related to pre-K, like crime. Four more stories were added after entering search terms "early childhood education" and "prekindergarten." Sixty-five articles were collected from The New York Times for preliminary analysis (see appendix D), of which 49 were ultimately analyzed.

WNYC. The WNYC website was last redesigned in 2013. WNYC publishes stories from national sources such as NPR and The Takeaway, but only stories collected on the local education blog "SchoolBook" were considered. This is because I wanted to narrowly focus on how WNYC covered universal pre-K rollout for a local audience. As the search function on the WNYC website is more limited than either Chalkbeat or The New York Times, I pulled stories manually. Articles were included if the headline or onesentence summary indicated it was about pre-K. Six articles clearly labeled "Opinion" were not pulled. Occasionally, audio as broadcast was attached to the online version of a story. Text-to-speech software was used to create a transcript of the story as I played it, and the transcript was coded along with the web copy. Sixty-two articles from WNYC were collected for preliminary analysis, and all were analyzed (see appendix E). 


\section{NEWS FRAMING OF UNIVERSAL PRE-K ROLLOUT IN NYC}

\section{Author Positionality}

When I'm out reporting for my day job, I often mention that I am the child of a public school teacher. I want the people I'm interviewing to understand how my mom's experiences in the classroom have shaped my worldview. I've tried to be just as forthright about how my training as a journalist has influenced my research. It's impossible for me to read stories on my beat without thinking about what I would have done differently. As such, I kept a reporter's notebook at hand while I coded to jot down ideas I thought were clever - and pitfalls I wanted to remind myself to avoid in my own stories. Sometimes I had to ask myself, "Where is this interpretation coming from?" When the answer was my own experiences, I made a note so I could include a thoughtful explanation in my analysis. Peterson (2001) writes that readers are rarely privy to the complex journalist-source negotiations that happen behind the scenes. But fellow journalists are. In the next section, I will try to articulate how my training as an education reporter was an asset as I did this research. 


\section{NEWS FRAMING OF UNIVERSAL PRE-K ROLLOUT IN NYC}

\section{Results}

This study focuses on how three different media outlets - a niche nonprofit education blog, a national newspaper, and a public radio station - covered the rollout of universal pre-K in New York City in 2014. A total of 178 articles published by Chalkbeat New York, The New York Times, and WNYC between January 1 and December 31, 2014, were qualitatively coded for this comparative case study.

\section{Coding}

All articles were coded in accordance with the code book. A total of 19 articles three from Chalkbeat and 16 from The New York Times - were excluded from analysis because they were not about universal pre-K or otherwise pulled in error. Data collected was entered into two spreadsheets, sources by media type and frames by media type.

Sources by media type. Sources were entered into Excel by an identifier and a letter to denote the order in which they appeared. So "CHALK01A" would indicate the first source quoted in the article, "CHALK01B" would indicate the second, "CHALK01C" would indicate the third, and so on (see appendix G). A decision was made to create two additional source categories - "other education official" and "other government official.” This was done to account for official sources I did not want to classify as "other," including state education officials, federal education officials, mayors of municipalities other than New York, and politicians of national prominence. The “other” category ultimately comprised daycare providers, commentators, essayists, labor leaders, religious leaders, college administrators, and school staff that was neither teacher 


\section{NEWS FRAMING OF UNIVERSAL PRE-K ROLLOUT IN NYC}

nor administrator, such as parent coordinators and speech therapists. For repeat sources, I noted whenever the source was described in a way I had not seen before. In 2014, Chalkbeat quoted 189 non-unique sources on universal pre-K; The New York Times, 204; and WNYC, $171 .{ }^{3}$ From this data, three pie charts - one for each news outlet - were created to show the sourcing breakdown by media type.

Frames by media type. In order to ensure my coding was consistent, I randomly pulled five code sheets from each case at the end to make sure my coding process had not changed. I actually ended up going back to a subset of WNYC articles - those with conflict frames - and coding them a second time because I felt my understanding of the frame had evolved as I worked my way through the sample. Then it was time to enter my data into Excel. A “1” was entered if a generic news frame - conflict, human interest, economic consequences, morality, or attribution of responsibility - was present in the story. A “0” was entered if it was not. A story could contain multiple generic news frames, or none at all. Likewise, a "1" was entered if the education-specific failing schools frame identified by Hogan (2013) was present in the article. A " 0 " was entered if the story did not use language of failing schools to describe the performance of students or otherwise sensationalize pre-K. The columns were then totaled so percentages could be calculated (see appendix H). From this data, a bar chart was created to show the frequency with which each frame was used.

\footnotetext{
${ }^{3}$ If audio was available for a WNYC story, it was coded, too. Often, sources would appear in the version for broadcast that were not in the web story. These sources - the majority of whom were parents, students and classroom teachers - are included in the 171 .
} 


\section{NEWS FRAMING OF UNIVERSAL PRE-K ROLLOUT IN NYC}

\section{Sourcing}

All three media outlets relied on official sources to provide information about the rollout of universal pre-K in New York City in 2014. The single largest category for every publication was "New York City officials." This finding is consistent with previous sourcing studies (Walejko \& Ksiazek, 2010). However, The New York Times - in this study, the legacy newspaper - was one and a half times more likely than Chalkbeat or WNYC to quote from government officials in general. Forty-five percent of sources that appeared in The New York Times were either city officials, state officials or "other government officials," a category that was created to account for national politicians and mayors of municipalities other than New York City. In comparison, 31 percent of sources quoted by Chalkbeat and 32 by WNYC were government officials.

Interestingly, it was WNYC that talked to the most students and parents, interviewing them twice as often as Chalkbeat. I would like to note here that I did not ascribe any kind of value to a source's remarks in my analysis. So a child speaking a few words into a WNYC reporter's microphone was weighted the same as substantive remarks from an elected official. Other sourcing studies have counted words or number of quotes in an attempt to control for the quality of remarks. I felt that this was somewhat outside the scope of my analysis. No one expects a 4-year-old interviewed during snack time to be as articulate as de Blasio delivering prepared remarks. I just wanted to know if the child's opinion had been sought.

Sources in context. Although Chalkbeat, The New York Times, and WNYC quoted many of the same politicians, government officials, and educators during the 


\section{Figure 1: Source Breakdown by Media Type}

\section{Chalkbeat}

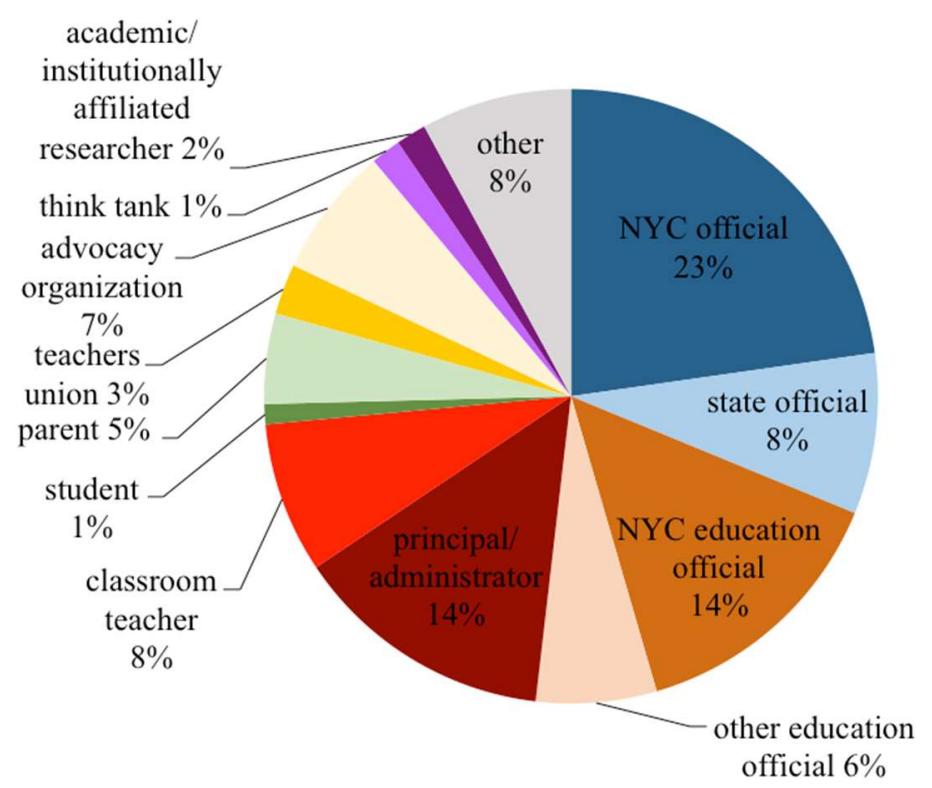

The New York Times

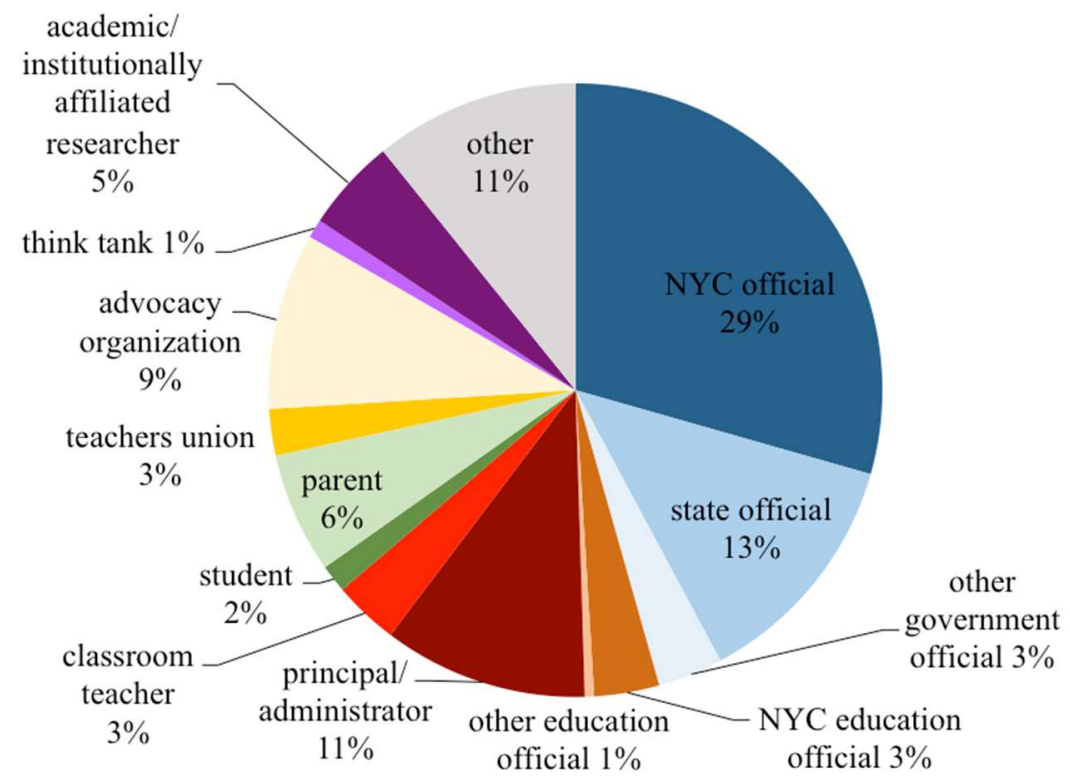




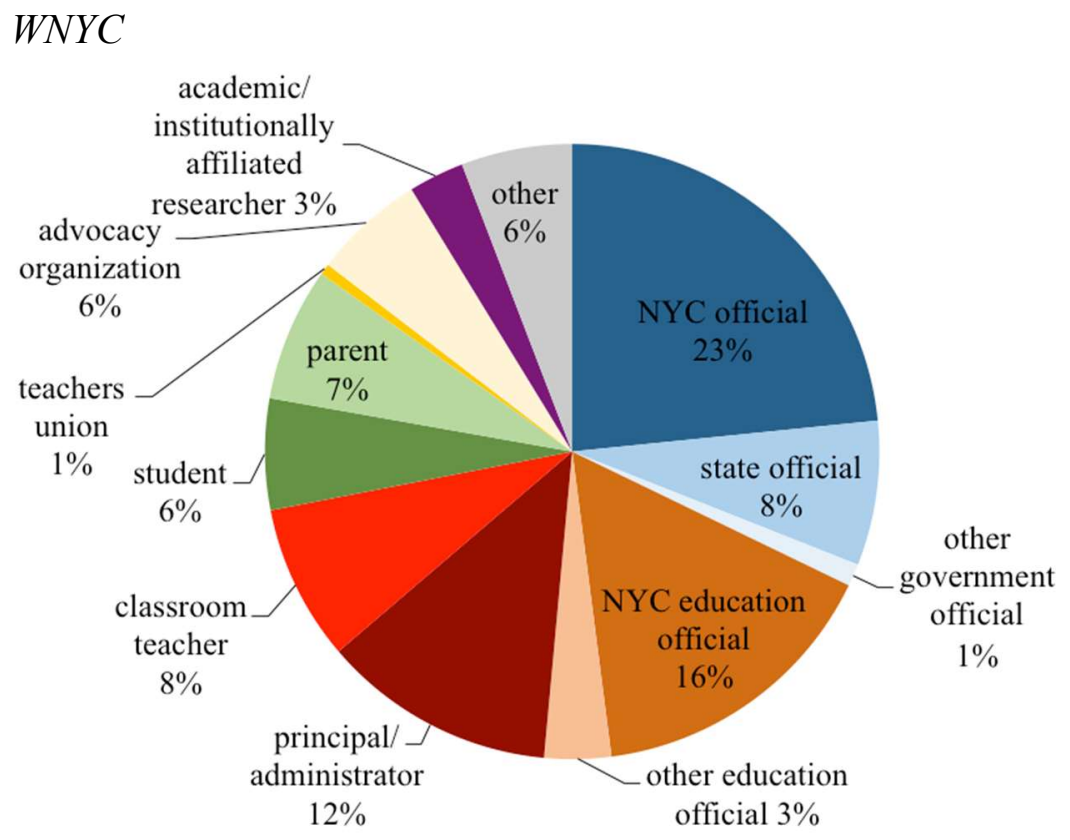

rollout of universal pre-K, the three media outlets frequently described sources differently. For example, Chalkbeat and WNYC typically attached Moria Cappio to the Children's Aid Society when they sought her opinions. But Cappio became "an early childhood expert" in a New York Times report on how daycare operators were reacting to the city's investment in universal pre-K (Ishayik, 2014). Sometimes, reporters at the same publication would identify a source differently. Such was the case with David Levitan, who was quoted as both the vice president of a public affairs firm (Stewart, 2014b) and the spokesman for an advocacy organization (Grynbaum, 2014b) in The New York Times. To be clear, Stewart did not change jobs - his firm had been hired to represent UPKNYC, the political campaign for universal pre-K. Occasionally, a reporter would change how he or she described a source over time. Hiro Yoshikawa was an "expert” when WNYC talked to him in October (Shulman, 2014r) but a professor of education at New York 


\section{NEWS FRAMING OF UNIVERSAL PRE-K ROLLOUT IN NYC}

University when he was quoted in December (Shulman, 2014y). Yoshikawa did not change jobs, either.

Haas (2007) has criticized education journalists for failing to contextualize the policy positions of the advocacy organizations and think tanks they quote. Indeed, Massachusetts-based IHS Global Insight became "a worldwide information company" in The New York Times (Stewart, 2014d), language that does not necessarily communicate IHS Global Insight is a think tank. ${ }^{4}$ WNYC quoted from statements released by StudentsFirstNY and Educators 4 Excellence without any additional context, so a reader unfamiliar with these two reform-oriented groups would know only that they support merit pay, unlike teacher unions (Fertig, 2014a). This was not unique to WNYC. All three media outlets routinely used this kind of shorthand in their coverage. For instance, Citizens Union was "a government watchdog group" in a New York Times article about a budget deal to fund universal pre-K (Kaplan \& Hernández, 2014b). Haas has advocated for the inclusion of sources' credentials whenever possible. Chalkbeat did, occasionally, detail the qualifications of sources to speak on a subject, such as to note that an education department official did not actually have any teaching experience (Cramer, 2014g).

The failure to contextualize can at times result in serious omissions, as was the case with a pro-charter rally in Albany both Chalkbeat and The New York Times covered. The rally occurred while de Blasio was at the statehouse to make an appeal for universal pre-K. The charter rally, attended by de Blasio's political rival, New York Governor

\footnotetext{
${ }^{4}$ Although sources affiliated with think tanks ended up being an insignificant part of all three media outlets' coverage, I decided to leave them their own category because there is so much concern among researchers about their proliferation in the education policy sector.
} 


\section{NEWS FRAMING OF UNIVERSAL PRE-K ROLLOUT IN NYC}

Andrew Cuomo, ended up overshadowing the pre-K event. Chalkbeat noted that Eva Moskowitz, the leader of Success Academy, had “given generously” to Cuomo's reelection campaign (Decker, 2014h). But it was The New York Times that provided crucial context as to why Moskowitz's presence was noteworthy:

But eight years into her crusade, Eva S. Moskowitz is locked in combat with a new mayor, Bill de Blasio, who repeatedly singled her out on the campaign trail as the embodiment of what he saw was wrong in schooling ... (Baker \& Hernández, 2014)

Because Chalkbeat does not explain that de Blasio had targeted Moskowitz's charter schools, only that his campaign rhetoric had been decidedly anti-charter, the significance of her appearance at the rally is lost.

However, it was Chalkbeat that was better at tracing the paths of officials into the education department than The New York Times or WNYC. For instance, Chalkbeat covered the departure of Shael Polakow-Suransky, a holdover from the previous administration who did not get along with incoming schools chancellor Carmen Fariña (Cramer \& Darville, 2014). Chalkbeat also examined how de Blasio built a coalition of support for universal pre-K by courting the supporters of his primary challengers (Decker, 2014a). In general, Chalkbeat and WNYC were much more likely than The New York Times to quote education officials, turning to them nearly five times as often.

Bill de Blasio. The mayor was ever-present in coverage of universal pre-K rollout in New York City. Chalkbeat, The New York Times, and WNYC all quoted de Blasio more frequently than any other individual. In fact, taken as his own category, de Blasio made up 14 percent of all sourcing on the topic of universal pre-K. Even in stories not ostensibly about him, de Blasio was a central figure. In a story about the state budget, 


\section{NEWS FRAMING OF UNIVERSAL PRE-K ROLLOUT IN NYC}

Khan writes, "It hasn’t been New York City Mayor Bill de Blasio’s easiest week"

(2014e). When de Blasio failed to secure funding for an afterschool program he wanted, Fertig reported, "The mayor did not get ..." when it was really middle schoolers who would go without (2014i). Again and again, universal pre- $\mathrm{K}$ is the mayor's "signature issue" (Shulman, 2014c) or else his "signature initiative" (Decker, 2014t; Grynbaum, 2014a; Shulman, 2014t). All three media outlets framed universal pre-K as a campaign promise of de Blasio.

\section{Framing}

A total of 178 articles were qualitatively coded for the presence of the five generic news frames. I also marked language commonly associated with the education-specific frame of failing schools (Briggs, 2012; Hogan, 2013). Finally, I identified a frame specific to coverage of universal pre-K rollout in New York City that questioned de Blasio's ambitious implementation timeline.

Generic news frames. The five generic news frames are attribution of responsibility, conflict, human interest, economic consequences and morality (Semetko and Valkenburg, 2000). Conflict was by far the most common news frame identified in the sample, occurring in one-third of stories about universal pre-K in 2014. In fact, The New York Times used a conflict frame in nearly half of its pre-K stories, three times as often as WNYC, which only used a conflict frame 16 percent of the time. Chalkbeat used conflict to frame its pre-K coverage 39 percent of the time. WNYC, the only one of the three media outlets for which conflict wasn't the most common generic news frame, was more likely to focus on the economic consequences of universal pre-K. 


\section{NEWS FRAMING OF UNIVERSAL PRE-K ROLLOUT IN NYC}

Conflict. From de Blasio's inauguration on, Chalkbeat and The New York Times used conflict frames in their coverage of universal pre-K. The mayor's predecessor, Michael Bloomberg, "sat unsmiling a few feet away" (emphasis added), according to a recap of the festivities that ran in The Times (Grynbaum, 2014a). A few weeks later, Polakow-Suransky would leave the New York City Department of Education because "his ties to the Bloomberg administration, which Fariña has said she left in 2006 because of philosophical differences, were deep" (Cramer \& Darville, 2014). Chalkbeat also reported that Fariña's education department had quietly scrapped Bloomberg's "Children First" initiative, referring instead to "school enhancement projects" (Cramer, 2014d). Conflict frames were used to set up the showdown between de Blasio and Cuomo, de Blasio's clash with charter school operators, and even the competition between schooland community-based preschools for students and teachers.

Conflict between de Blasio and Cuomo. By far the most prevalent conflict in coverage of universal pre-K was between the mayor and Governor Cuomo, at odds on how to pay for universal pre-K. Writes Grynbaum for The New York Times:

Dueling news conferences, 150 miles apart, offered a vivid portrait of this year's most intriguing political showdown: the upstart mayor and the up-for-re-election governor, Democratic colleagues and ostensible friends, who may end up on sharply different sides of the issue on which Mr. de Blasio has staked his young administration. (Grynbaum \& Craig, 2014)

The headline? "Clash of Priorities Sets Up Cuomo-de Blasio Showdown on Pre-K Push." The New York Times both calls universal pre-K "a glittering prize" and treats it as such, framing it not in benefits for kids and families, but in terms of political points scored (Grynbaum \& Kaplan, 2014a). The governor must adjust "to a fresh and frustrating 
NEWS FRAMING OF UNIVERSAL PRE-K ROLLOUT IN NYC

Figure 2: Generic News Frames By Media Type

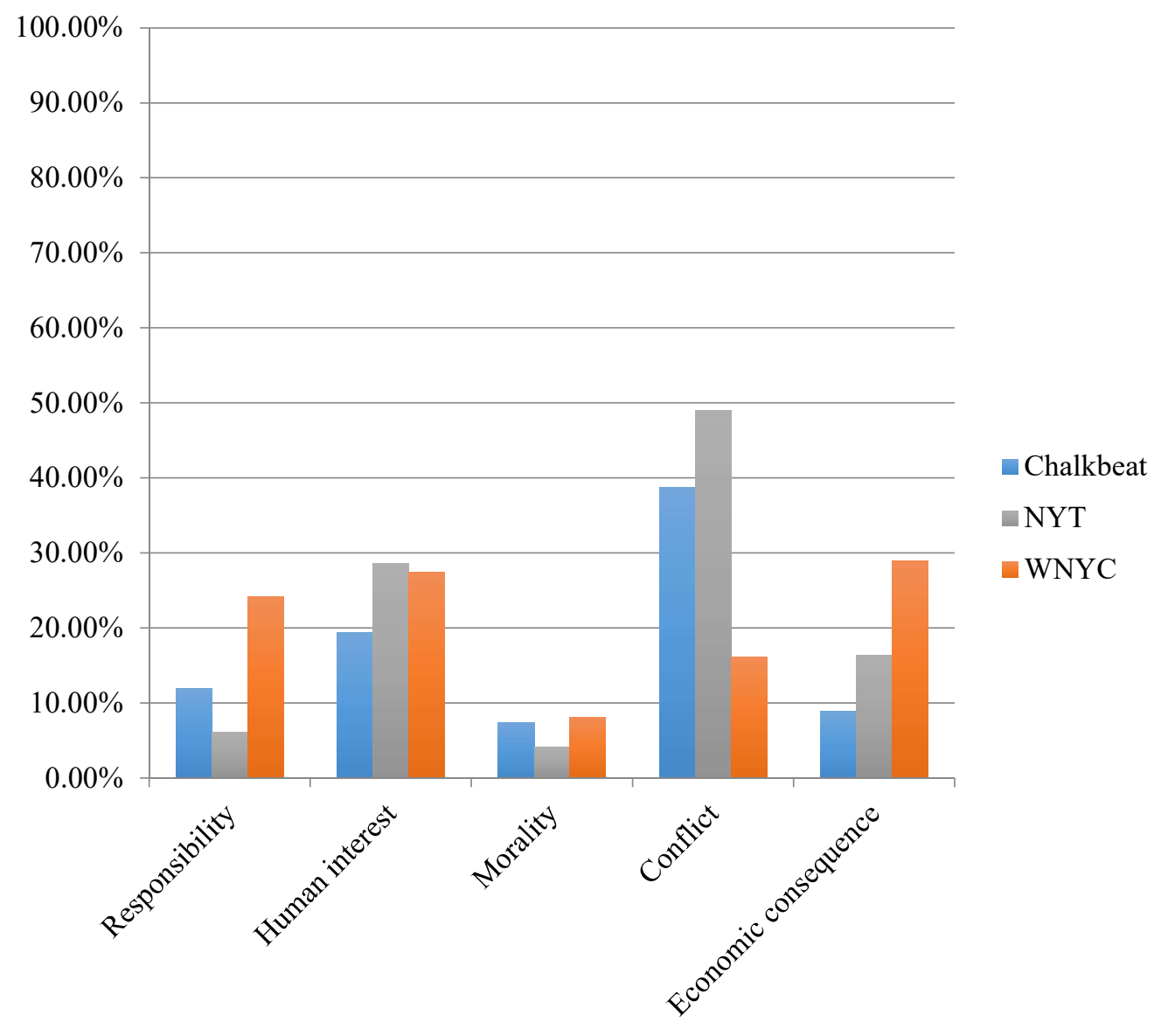

reality" when de Blasio refuses state money for pre-K, preferring to raise funds through a citywide tax on wealthy residents (Kaplan, 2014b). In late January, The New York Times reported that the mayor and the governor had held a joint press conference at a hospital, an event "intended to telegraph, through words and backslapping, that all was right between Mr. Cuomo and Mr. de Blasio" (Kaplan \& Hernández, 2014a). But The Times, reluctant to let go of the conflict narrative, reported that the education commissioner "found himself in the middle of a heated brawl" between Cuomo and de Blasio (Hernández, 2014c). According to The New York Times, Cuomo went so far as to coordinate an attack on de Blasio’s tax plan vis-à-vis like-minded mayors (Dwyer, 2014a; 


\section{NEWS FRAMING OF UNIVERSAL PRE-K ROLLOUT IN NYC}

Kaplan, 2014d). When de Blasio finally agrees to state funding for universal pre-K, The New York Times records it as a win for Cuomo, who "at every turn ... has not only stymied the mayor, but also seized the moment for his own gain" (Craig \& Grynbaum, 2014). The New York Times' coverage of universal pre-K read like a political thriller, not education reporting.

WNYC also used conflict frames in its coverage of the pre-K funding fight at the statehouse, though more sparingly than The New York Times. "Cuomo didn't mention de Blasio," writes Fertig of the governor's budget address, “but he didn't need to. It was clear he was saying he had a better way of getting de Blasio's proposals accomplished" (2014c). In the anchor-read intro of a story about behind-the-scenes political maneuvering, de Blasio gets “a big splash of cold water from Albany” (Fertig, 2014f). Fertig goes on to report, "Cuomo's line of attack marks a new phase in his assault on de Blasio's push to tax city residents.” Months later, Shulman explains that Department of Education officials are carefully tallying pre-kindergartners because "a high enrollment figure would be a political win" (2014q). Much like in The New York Times, it's all about who scores the political point.

Conflict with charter schools. Chalkbeat focused less on political infighting and more on de Blasio's heated campaign rhetoric surrounding charters. At issue was whether the city's charter schools would be allowed to house new pre-K classrooms. At a statehouse rally, "Gov. Andrew Cuomo repeatedly pledged to 'save charter schools' in fiery remarks ... (his) appearance stoked simmering criticism that the charter rally had been organized as little more than a distraction" to draw attention away from de Blasio, 


\section{NEWS FRAMING OF UNIVERSAL PRE-K ROLLOUT IN NYC}

who was testifying before state lawmakers at the time (Decker, 2014h). Chalkbeat

reporters occasionally used language that read as pro-charter, describing the state law that barred charters from getting public preschool funds as a "hurdle" supporters would have to overcome (Decker, 2014c). "Thanks to a change in state law," WNYC reported, charters would finally be able to receive pre-K funding (Khan, 2014p). Likewise, this could be read as pro-charter.

School-versus community-based pre-K. Chalkbeat was the only one of the three media outlets to really explore the tension between school- and community-based pre-K. Teachers at community-based preschools are often paid significantly less than their public school counterparts (Wall, 2014a). As a result, they usually leave for better paying jobs a few years after they are trained. Although both The New York Times and WNYC reported on the pay disparity, only Chalkbeat explained the policy implications:

Researchers and pre-K providers say that pay gap drives some of the most experienced teachers to public schools, fueling a "tale of two cities" within the public preschool system. De Blasio's sweeping plan to provide free pre-K to all four-year-olds calls for "comparable" pay and more oversight for all preschool teachers, which those close to the system say is essential if the mayor wants to raise the quality of pre-K across the city. (Wall, 2014a)

While daycare quality is often reported on in conjunction with pre-K, as both are key components of early childhood education delivery, only The New York Times did a story on the impact of universal pre-K on daycare providers (Ishayik, 2014).

Economic consequences. WNYC was twice as likely as The New York Times and more than three times as likely as Chalkbeat to frame universal pre-K in terms of economic consequences. Although WNYC sometimes applied conflict frames to de Blasio's dispute with Cuomo, more often reporters described the budgetary impact of the 


\section{NEWS FRAMING OF UNIVERSAL PRE-K ROLLOUT IN NYC}

back-and-forth between the two Democrats. Here's how WNYC described the nuts and bolts of the two plans:

De Blasio's supporters note that Cuomo's budget for pre-K wouldn't even cover New York City alone, the cost of which is estimated at $\$ 340$ million for an additional 48,000 full-day seats. Cuomo's increase would start at $\$ 100$ million the first year and gradually ramp up each year. (Fertig, 2014c)

In general, WNYC used more neutral language than Chalkbeat and especially The New York Times to talk about de Blasio's “request to raise taxes, temporarily, on city residents earning more than $\$ 500,000$ per year" (Khan, 2014c). In Chalkbeat, it's "increasing taxes on the city's highest earners" (Cramer, 2014c) or a "tax-the-rich proposal" to pay for preK (Decker, 2014i). But in The New York Times, it's unambiguously a tax on the wealthy.

Times reporters routinely used evocative language to emphasize that income inequality was fueling the fight over how to pay for pre-K. Writes Powell of de Blasio's administration, "They want to take a city focused intently on the top and train its eyes on the remaining 97 or 98 percent" (2014a). This is a mayor who won by "assailing the gap between rich and poor" (Hernández \& Stewart, 2014). The idea that the city could pay for pre-K by increasing taxes on wealthy New Yorkers was "an idea rich with symbolism that many hoped would galvanize liberal causes across the country" (Hernández \& Kaplan, 2014). Yet The New York Times only used an economic consequences frame 16 percent of the time. How did I come to this conclusion? To determine whether a conflict or an economic consequences frame had been applied, I returned to the questions in the code book. One of the questions Semetko and Valkenburg asked was, "Is there a reference to economic consequences of pursuing or not pursuing a course of action?" (2000, p. 100). Whenever the answer was “no," I would test for a conflict frame. "Does 


\section{NEWS FRAMING OF UNIVERSAL PRE-K ROLLOUT IN NYC}

one party-individual-group-country reproach another? ... Does the story refer to winners and losers?" More often than not, the answer was "yes," so I coded those articles accordingly. I think New York Times reporters may have been taking their cues from the governor. "He's saying part of what he ran on is income inequality, and part of the answer to income inequality is taxing rich people ... that's a political position" the governor is quoted as saying in The Times (Kaplan, 2014b). As a result, universal pre-K coverage in The New York Times rated high on conflict but low on economic consequences.

Finally, economic consequence frames were sometimes used by the three media outlets in stories not about the dispute over pre-K funding. One example would be in Chalkbeat's reporting on the pay disparity between school- and community-based preschools (Wall, 2014a). When WNYC covered the wage gap, Fertig wrote that de Blasio wanted to "hike teachers' salaries" (2014k). This feels like a good time to note my positionality as an education reporter who covers pre-K. We're talking about a profession that pays $\$ 44,000$, but requires a college degree - I would have described it as a pay increase, not a salary hike.

Human interest. Fortunately, education reporting has moved beyond "what it's like to fold an adult frame into a first-grader's chair" (McQuaid, 1989, p. K5). That's not to say reporters never invoked this imagery. A parent "filled out forms on a child-size chair" in a Chalkbeat story on the first day of school (Glazer \& Wall, 2014). And WNYC actually updated this trope with a clever report on a furniture manufacturer scrambling to meet increased demand (Shulman, 2014c). A quarter of articles in the sample contained 


\section{NEWS FRAMING OF UNIVERSAL PRE-K ROLLOUT IN NYC}

human interest frames, with The New York Times using them the most and Chalkbeat, the least.

The New York Times used human interest frames 29 percent of the time. For example, de Blasio is described as "a tall crane of a man" who had to edge his way "into a low-ceilinged conference room in Downtown Brooklyn" to celebrate his own mayoral victory (Powell, 2014a). Grynbaum notes that a television spot featuring de Blasio's wife, Chirlane McCray, and the couple's biracial children helped the mayor regain his political footing (2014b). Of de Blasio’s advisors, Stewart writes, “The longtime fraternity of government power ... now resembles a sorority where women are helping set (the) agenda" (2014c). One of the most interesting and unique stories in the sample explains how the city's investment in pre-K is affecting daycare providers. Instead of squeezing them out, Ishayik reports it's encouraging them to improve quality and seek licensure (2014). Keep in mind The New York Times talked to fewer students and parents than WNYC, but more than Chalkbeat.

Human interest elements are a crucial part of radio storytelling, which might explain why this frame is present in 27 percent of WNYC's coverage. One example of this is a sound-rich feature about the recruiters approaching the families of young children at festivals and other community events (Shulman, 2014g). But some of the best details from the audio, such as the description of children unsteady on their feet as "little walkers," weren't in the web version. This actually occurred frequently with WNYC. Stories that were a compelling listen were not a compelling read because all the human interest elements had been cut out. 


\section{NEWS FRAMING OF UNIVERSAL PRE-K ROLLOUT IN NYC}

Attribution of responsibility. An attribution of responsibility frame typically assigns blame. This was observable in the sample. For example, in WNYC's recapping of the dust-up between de Blasio and the city's comptroller, "the mayor's office is late to submit contracts" (Shulman, 2014h). But more interesting was an atypical use of the attribution of responsibility frame that emerged in WNYC's coverage. In this case, the mayor was credited for expanding access to pre-K. Another way to describe this application of the frame would be praise. "De Blasio has set the bar high," reports WNYC, quoting one of the mayor's aides as saying his boss "moved heaven and earth" to get the bureaucratic process going (Shulman, 2014k). At first, I wasn't sure if this was truly an example of attribution of responsibility, so I again turned to the framework provided by Semetko and Valkenburg (2000). Yes, the story suggests that the government can alleviate the problem. Yes, the story suggests some level of government is responsible for the problem. Indeed, WNYC was attributing responsibility, albeit in a slightly unusual way. WNYC was twice as likely as Chalkbeat and four times as likely as The New York Times to use the attribution of responsibility frame.

Like WNYC, Chalkbeat used the attribution of responsibility frame to both praise and blame. Chalkbeat reporters were particularly focused on the handoff from the mayor's office to the city's pre-K teachers. Writes Sokoloff-Rubin, "The success of the mayor's flagship universal pre-K initiative will soon rest in large part on the interactions between 53,000 4-year-olds and their teachers" (2014e). Chalkbeat also used the attribution of responsibility frame to highlight the tension between de Blasio's ambitious pre-K plan and the needs of the rest of the school system. A report by Wall captures the 


\section{NEWS FRAMING OF UNIVERSAL PRE-K ROLLOUT IN NYC}

frustration of principals who were told by the New York City Department of Education they needed a school improvement plan and weren't given any feedback when they submitted one. "They put all their emphasis on preschool," Pedro Noguera, an education professor at New York University, told Chalkbeat, “but they don't seem to get that they're dealing with a much larger system" (Wall, 2014f). In this case, the fact that de Blasio took responsibility for pre-K isn't praiseworthy because he neglected other duties to do so.

The New York Times used the attribution of responsibility frame less often than the other two outlets, and when it did, it was usually to record political points. "Mayor de Blasio stumbled away from the first state budget battle of his administration with his mandate bruised and his political momentum stymied, but clutching a hard fought prize: money, and a lot of it," The New York Times reported (Grynbaum \& Kaplan, 2014b). Taylor writes that the purpose of a lobbying group formed at the mayor's behest "seems to be less to push for Mr. de Blasio's proposals than to make sure he gets credit for his achievement afterward" (2014b). The New York Times did not use this frame to credit or praise de Blasio for expanding access to pre-K.

Morality. Returning to the questiones asked by Semetko and Valkenburg (2000), a story contains the morality frame if it contains moral messages, references God or other religious tenants, or offers specific social prescriptions about how to behave. Note that this is a fairly narrow definition of morality, one that would not necessarily encompass de Blasio's income inequality rhetoric. As a result, I detected morality frames in less than 10 percent of the articles I coded. Asking different questions to test for morality frames 


\section{NEWS FRAMING OF UNIVERSAL PRE-K ROLLOUT IN NYC}

likely would have yielded different results. While I found Semetko and Valkenburg's conceptualization of the morality frame useful for the purposes of my analysis, future researchers may make another call. I would be very interested in how morality, more broadly, has shaped the news framing of education coverage.

That said, The New York Times framed pre-K in terms of morality only twice, in coverage of de Blasio's inaugural address (Grynbaum, 2014a; Powell, 2014a). Chalkbeat and WNYC, on the other hand, were nearly twice as likely as The New York Times to explicitly frame universal pre-K explicitly in terms of morality. According to WNYC, "Universal pre-K ... is seen as a way to help children of all different economic backgrounds develop the skills they need to be good learners" (Fertig, 2014j). In Chalkbeat's coverage, moral messages were usually source-supplied by de Blasio himself, as was the case in a recap of his budget address to lawmakers (Cramer, 2014c).

Failing schools. Newspaper reporters wrote about schools that were "failing," "underachieving," and "ineffective" as a result of NCLB (Briggs, 2012; Cavazos, 2014; Hogan, 2013). But by 2014, the year of universal pre-K rollout in New York City, most states had waivers excusing them from Bush-era accountability rules. The language of failing schools was used in less than 6 percent of articles in the sample, most often by WNYC and Chalkbeat and only occasionally by The New York Times. Usually it was a politician who would trigger the failing schools frame. "De Blasio argued that any challenge standing in the way of his plan paled in comparison to the education crisis facing New York City schools," writes Decker for Chalkbeat (2014e). Other times, student performance was cited as a reason why universal pre-K was necessary. "Only 


\section{NEWS FRAMING OF UNIVERSAL PRE-K ROLLOUT IN NYC}

about 30 percent of elementary and middle school students, statewide, scored proficient" in reading and math, writes Fertig (2014b). Reporters mostly avoided the urge to sensationalize pre-K, though in a dust-up between the mayor and Scott, Stringer, the city comptroller, The New York Times did quote Stringer as saying, "We're dealing with little 4-year-old children. It would be malpractice on my part" (Taylor, 2014d). Stringer, angry that his office had not seen all of the city's pre-K contracts yet, accused de Blasio of jeopardizing the health and safety of children. Since the vast majority of those sites were allowed to open a few weeks later, it's unlikely the situation was as dire as Stringer suggested.

Early childhood education research. The New York State Assembly wasn't the

only legislative body debating pre-K funding in 2014. That year, Indiana Governor Mike Pence asked state lawmakers to approve funding for a small-scale preschool pilot program. The question of whether pre-K worked sharply divided statehouse Republicans. Based on my experience covering that debate, I expected de Blasio to meet similar resistance from New York lawmakers reluctant to invest millions in early childhood education. Except there the value of pre-K was a foregone conclusion. "There is no dissent on that," writes Dwyer in The New York Times (2014b). This could by why reporters from the three media outlets used early childhood education research so sparingly. Academic and institutionally affiliated researchers made up just 5 percent of all sources quoted on pre-K in The New York Times, and just 2 percent and 3 percent in Chalkbeat and WNYC, respectively. Oftentimes, research into whether pre-K worked was referenced but not cited. For instance, in a WNYC story about recruiting pre-K 


\section{NEWS FRAMING OF UNIVERSAL PRE-K ROLLOUT IN NYC}

teachers, Shulman writes, "Many of them are talking about the same quality:

responsiveness. Research shows this quality most impacts young children” (2014b). But

Shulman doesn't provide a source for her assertion. This could be because there is a

consensus among education researchers that pre-K is worth the investment (Wong,

2014b). It could also be because radio reporters are constrained by the clock and cannot argue with their editor for another column inch.

It's worth noting that both Chalkbeat and The New York Times talked to researchers who pointed out that a targeted program for low-income children might be more beneficial for school readiness than universal pre-K (Glazer, 2014g; Hernández, 2014b). However, since "such a program might not be politically palatable in New York, where preschoolers in middle class neighborhoods have long waiting lists," that research was never part of the conversation (Hernández, 2014b). Accordingly, none of the media outlets in the study framed their coverage of universal pre-K that way.

Are we moving too fast? Reporters from all three media outlets routinely asked city officials if they would be able to meet their self-imposed September deadline. They wrote story after story about how many classrooms would have to be found, how many teachers would have to be trained, how many children would have to be enrolled. In my notes, I dubbed this frame, “Are we moving too fast?" I suspect other education reporters who have covered the implementation of new policies will find my description of this frame familiar.

As early as March, WNYC was reporting that de Blasio's administration and the New York City Department of Education might not be able to pull it off. Parents were 


\section{NEWS FRAMING OF UNIVERSAL PRE-K ROLLOUT IN NYC}

applying for pre-K seats in classrooms that did not yet exist (Fertig, 2014h). A month later, Khan reported that "expectations must be tempered" as the city rapidly scaled up its investment in public preschool (2014i). According to Fertig, "1,000 teachers were quickly hired and trained" in the rush to create more seats (20141). Even parents who supported the mayor's vision agreed everything was happening too fast (Shulman, 2014k). WNYC even seemed to suggest that some problems - nine pre-K providers were shuttered just days before the school year was supposed to start - could have been avoided if the city had not moved so fast (Shulman, 2014j).

Chalkbeat reporters expressed skepticism even earlier, in January. Decker reports that state lawmakers “fretted about de Blasio's ambitious implementation schedule" when they learned his department planned to add an additional 55,000 seats over the course of two years (2014e). According to Darville, de Blasio had "imposed a very long to-do list on the Department of Education" (2014a). She, too, labeled the mayor's timeline "ambitious" (2014e). Wall described city officials as being in "an all out sprint" to open new pre-K classrooms by September (2014e). Although this frame was used more frequently by Chalkbeat and WNYC, The New York Times also questioned the city's preparedness, calling a pre-K report prepared by the mayor's office "short on details" (Kaplan \& Hernández, 2014a). It's possible that the number of education officials and teachers WNYC and Chalkbeat talked to influenced this frame. 


\section{NEWS FRAMING OF UNIVERSAL PRE-K ROLLOUT IN NYC}

\section{Discussion}

At first glance, the sourcing practices of Chalkbeat journalists do not appear to be substantively different than reporters at the newspaper of record, The New York Times, and the public radio station, WNYC. After all, city officials were quoted most often in all three news organizations, just as countless other investigations have concluded. Likewise, the pervasiveness of conflict frames might discourage journalists and education researchers who hoped the NCLB era of persistently negative schools coverage was over. However, as an education reporter committed to taking listeners into schools, I actually feel there is a lot to be excited about in these results.

\section{Sourcing}

First and foremost, this comparative case study was conceptualized as a way to better understand the sourcing practices of journalists at niche publications.

RQ1: How do the sourcing practices of journalists at niche news organizations differ from those who work for legacy media?

Education news nonprofits like Chalkbeat have a very different revenue structure than legacy media, and critics charge there's no way the foundations funding their work won't hold sway. However, I did not find that Chalkbeat gave advocacy organizations more of a voice than the other media outlets. In fact, The New York Times turned to advocacy organizations for comment slightly more often than Chalkbeat. Chalkbeat reporters did, occasionally, use language that could be read as pro-charter. Of course, my analysis was limited in scope to universal pre-K coverage, but at no point in my analysis did I detect an anti-traditional public schools tone in the sample. As such, I'm inclined to say the 


\section{NEWS FRAMING OF UNIVERSAL PRE-K ROLLOUT IN NYC}

partiality to charter schools was unintentional, though future research could certainly ask whether Chalkbeat is more reform-oriented than other news organizations that cover education policy.

I was expecting Chalkbeat and the other two media outlets to rely on government officials for quotes, based on the literature and my own experiences as a reporter. Indeed, a third of Chalkbeat's sources on universal pre-K were local, state or national political figures. However, Chalkbeat and WNYC reporters also tapped into expertise at the New York City Department of Education, something journalists at The New York Times were less inclined to do. This feels like a step in the right direction, as it's usually the department that implements policy. Many education officials are subject matter experts, though reporters should always ask what a source's qualifications to speak are. This is especially true when an education official's appointment was politically motivated.

In the future, Chalkbeat reporters should consider talking to more students and parents. Students and parents made up just 6 percent of Chalkbeat's sources on pre-K in 2014, compared to 8 percent of The New York Times' and 13 percent of WNYC's. Chalkbeat did talk to more administrators than both The New York Times and WNYC, and more teachers than The New York Times. This is encouraging because talking to a superintendent or principal is usually the first step a reporter must take to enter a school. In general, education reporters agree that schools coverage lacks student voices due to the challenges of securing access and obtaining permission to interview children younger than 18. One of the ways WNYC gets around this is by using ambient sound recorded inside the classroom and not identifying students by name. Although the journalistic 


\section{NEWS FRAMING OF UNIVERSAL PRE-K ROLLOUT IN NYC}

preference is to use a source's first and last name, this is one way to get more student voices into stories without having to seek permission from parents. I would still challenge education reporters to use full names whenever possible. Kids are rarely easy interviews, but they're always the most important part of the story.

\section{Framing}

I expected universal pre-K to be framed as a campaign promise of Mayor Bill de Blasio, and it was. Somewhat more surprising was how often it was framed in terms of conflict - between de Blasio and Cuomo, between de Blasio and charter schools, even between school- and community-based preschools.

RQ2: How did each news organization frame universal pre-K rollout in New York City?

Before my deep dive into the issue, I would have expected the debate to be between preschool advocates and those skeptical that early childhood education is worth the investment. But that's not how it played out in New York City in 2014.

Chalkbeat and The New York Times both relied on conflict to frame the rollout of universal pre-K. Yet their coverage was completely different. The New York Times was focused on the political implications of funding universal pre-K with a tax on the wealthy, something that de Blasio had championed but Cuomo successfully opposed. Even though de Blasio ostensibly got what he wanted, and there's an argument to be made that the real winners were low-income New Yorkers who otherwise couldn't have afforded preschool, The Times reported that Cuomo won. Contrast that with Chalkbeat, which was focused on the education policy implications of universal pre-K. To get the pre-K seats he wanted, the mayor had to walk back his anti-charter rhetoric and agree to 


\section{NEWS FRAMING OF UNIVERSAL PRE-K ROLLOUT IN NYC}

locate some of those seats in charter schools, a decision with broad implications for the entire New York City education system.

WNYC went in an entirely different direction with its pre-K coverage, which was framed in terms of economic consequences. This is especially interesting because WNYC actually used more neutral language than Chalkbeat or The New York Times to describe de Blasio's plan to pay for pre-K. In a lot of ways, WNYC's coverage of universal pre-K is straightforward statehouse reporting - here's what's been proposed, here's how much it'1l cost, here's who's supporting it. Rarely does WNYC frame universal pre-K in terms of income inequality.

One of the most interesting frames to emerge from my analysis was the positive attribution of responsibility. Usually, this frame assigns blame, but Chalkbeat and WNYC were quick to credit de Blasio for making universal pre-K a reality for thousands of New York City's 4-year-olds. Praise for pre-K was far less effusive in The Times, which as the newspaper of record was much more critical of de Blasio than Chalkbeat or WNYC.

Although terrestrial radio is a legacy platform, I noted more similarity between Chalkbeat and WNYC than I did The New York Times and WNYC (or Chalkbeat and The New York Times, for that matter). My reasons for wanting to put a public radio station in my sample were personal, but WNYC's inclusion provided a useful point of comparison. I would advise future researchers to consider the mission and funding structure of public radio before categorizing it as legacy media as I did.

As we move beyond NCLB, it will be up to education reporters and researchers to monitor the pace of change. "Are we moving too fast?" could soon replace "Are schools 


\section{NEWS FRAMING OF UNIVERSAL PRE-K ROLLOUT IN NYC}

failing?" as the central question journalists ask. I doubt this frame is specific to universal pre-K. Educators have been telling me for the last five years that they simply can't keep up with mandates being handed down at the state and federal level. My prediction is this fatigue will only get worse as states submit new plans to the U.S. Department of Education under the Every Student Succeeds Act.

\section{Limitations}

Because I limited my search to the NY/Local section of The New York Times, columns and editorials were excluded from my sample, as was commentary from WNYC's Schoolbook blog. But editorials and commentaries can reinforce frames in news coverage (Shine, 2015). So too can images. We know very little about the visual framing of education coverage. Jones (2006) found that environmental journalists tended to use more evocative language in stories that ran with photographs of oil-soaked birds and marine mammals. While The New York Times employs staff photographers, Chalkbeat and WNYC reporters regularly take their own pictures. Another limitation of this comparative case study is that it did not consider visual elements such as photographs, only the text as prepared for online publication - or, in the case of WNYC, a transcript of the audio attached to the story as prepared by the researcher.

I have relied on Internet searches of consumer-facing websites to identify articles for analysis. Although none of the media outlets have undertaken a significant redesign in the years since 2014 , it is possible some stories about pre-K were missed. This is especially true for WNYC, which likely aired stories that staffers did not post to the website, as is common practice in radio. The researcher reached out to a former colleague 


\section{NEWS FRAMING OF UNIVERSAL PRE-K ROLLOUT IN NYC}

who now works for WNYC to ask if there might be a way to access this broadcast material. Although he agreed some education content that aired in 2014 probably wasn't posted to the SchoolBook blog, he said a more complete archive did not exist. However, WNYC is no longer publishing its SchoolBook blog. The education team has a new editorial strategy:

We are spending more time telling the stories of youth and families in the New York metropolitan region, what it means to grow up here or be a parent here, what are the conversations around the kitchen table or in the school hallways. Sure, we still cover schools but more with an eye on what the policies mean for families than the politicians. ("SchoolBook," 2016)

I think that's a great approach.

Which brings us to my positionality as a reporter and a researcher. The five years I've been on the beat have given me incredible insight into the thought processes of education journalists. They've also given me opinions about how to report the news, some of which you will find in this paper. Where appropriate, I have included my own experiences covering schools and students in an effort to be fully transparent about the biases I bring to this topic. Reading what other journalists have written about pre-K has reaffirmed my belief that education reporters have a responsibility to take audiences into schools with them as they report the news. I am heartened by the caliber of journalism I have seen from Chalkbeat, and I am optimistic new funding models for education news will mean more reporters covering this incredibly important topic.

Finally, there is a lot a working journalist can learn from this research. I've always said I cover education policy, not the politics of education. Something I have started doing recently is tracking who I talk to and how I describe them. I want to make 


\section{NEWS FRAMING OF UNIVERSAL PRE-K ROLLOUT IN NYC}

sure I'm talking to a variety of sources, which fits nicely into my station's mission to get more diverse voices on air. I'm trying to use more precise language in my reporting calling a professor I talk to frequently an "education expert" does not tell my listeners anything about his credentials, even if it saves me a breath or two. Meanwhile, everyone in the newsroom is probably tired of me correcting them when they talk about "K-12" education, but with so many school districts in our area are in the process of implementing universal pre-K, I'm wholly committed to telling the stories of Kansas City's youngest students. 
NEWS FRAMING OF UNIVERSAL PRE-K ROLLOUT IN NYC

\section{References}

Ansary, T. (2007, March 9). Education at Risk: Fallout from a Flawed Report. Retrieved August 3, 2017, from https://www.edutopia.org/landmark-education-report-nationrisk

Baitinger, G. (2015). Meet the Press or Meet the Men? Examining Women's Presence in American News Media. Political Research Quarterly, 68(3), 579-592.

Baker, M. (1994). Media Coverage of Education. British Journal of Educational Studies, 42(3), 286-297. https://doi.org/10.2307/3121887

Barthel, M. (2017, June 1). Newspapers Fact Sheet. Retrieved August 1, 2017, from http://www.journalism.org/fact-sheet/newspapers/

Bennett, W. L., \& Manheim, J. B. (2006). The One-Step Flow of Communication. The Annals of the American Academy of Political and Social Science, 608, 213-232.

Berkenbile, B. B. A. (2009). Crossing the school house gates: a media access audit of public high schools (Thesis). University of Missouri--Columbia. Retrieved from https://mospace.umsystem.edu/xmlui/handle/10355/6552

Berliner, D. C., \& Biddle, B. J. (1995). The manufactured crisis: myths, fraud, and the attack onAmerica's public schools. Reading, Mass: Addison-Wesley.

Bhuiyan, J. (2014, January 7). GothamSchools grows, goes national. Politico. Retrieved from http://www.politico.com/media/story/2014/01/gothamschools-grows-goesnational-001511

Boykoff, J. (2012). US Media Coverage of the Cancún Climate Change Conference. PS: Political Science and Politics, 45(2), 251-258.

Brennen, B. S. (2012). Qualitative Research Methods for Media Studies (1 edition). New York; London: Routledge.

Briggs, A. L. (2012). Framing and Media Attribution of Blame in Coverage of Failing Public Schools. Retrieved from

http://citation.allacademic.com/meta/p_mla_apa_research_citation/5/4/4/3/2/p5443 29 index.html

Brydie, I. (2014). A Pilot Study of Mass Media Frames and News Story Salience and Its Effect on Public Opinion and Policy Making. In NAAAS Conference Proceedings; 


\section{NEWS FRAMING OF UNIVERSAL PRE-K ROLLOUT IN NYC}

Scarborough (pp. 1373-1399). Scarborough, United States: National Association of African American Studies. Retrieved from http://search.proquest.com.proxy.library.umkc.edu/docview/1692817344/abstract/F B7DA370463849FAPQ/1

Campbell, S. (2010). Comparative Case Study. In A. Mills, G. Durepos, \& E. Wiebe, Encyclopedia of Case Study Research. 2455 Teller Road, Thousand Oaks California 91320 United States: SAGE Publications, Inc. https://doi.org/10.4135/9781412957397.n64

Carlson, C. S., \& Roy, M. (2014). Mediated Access: Education Writers' Perceptions of Public Information Officers' Media Control Efforts. Education Writers Association. Retrieved from https://www.spj.org/pdf/sunshineweek/ewa-survey-report-2014.pdf

Carragee, K. M., \& Roefs, W. (2004). The Neglect of Power in Recent Framing Research. Journal of Communication, 54(2), 214-233. https://doi.org/10.1111/j.1460-2466.2004.tb02625.x

Carr, S. (n.d.). Standards \& Ethics for Education Reporters. Retrieved April 8, 2017, from http://www.ewa.org/reporter-guide/standards-ethics-education-reporters

Cavazos, S. R. (2014). News framing of accountability systems after No Child Left Behind (Thesis). University of Missouri--Columbia. Retrieved from https://mospace.umsystem.edu/xmlui/handle/10355/44254

Chen, P. J. (Ed.). (2013). Elite digital media and digital media elites. In Australian Politics in a Digital Age (pp. 161-188). ANU Press. Retrieved from http://www.jstor.org.proxy.library.umkc.edu/stable/j.ctt2jbkkn.14

CPB Awards Grants to Strengthen Education Reporting. (2014, March 5). Retrieved May 21, 2017, from http://www.cpb.org/pressroom/cpb-awards-grants-strengtheneducation-reporting

Core Values. (2017, January 20). Retrieved from http://www.chalkbeat.org/about/ourcore-values/

Edmonds, R., Guskin, E., Rosenstiel, T., \& Mitchell, A. (2012). » Newspapers: By the Numbers. Retrieved from http://www.stateofthemedia.org/2012/newspapersbuilding-digital-revenues-proves-painfully-slow/newspapers-by-the-numbers/

Entman, R. M. (1993). Framing: Toward Clarification of a Fractured Paradigm. Journal of Communication, 43(3), 51-58. 


\section{NEWS FRAMING OF UNIVERSAL PRE-K ROLLOUT IN NYC}

Farley, R. (2013, February 20). Obama's Preschool Stretch. Retrieved October 18, 2017, from http://www.factcheck.org/2013/02/obamas-preschool-stretch/

Ferrucci, P. (2015). Public journalism no more: The digitally native news nonprofit and public service journalism. Journalism, 16(7), 904-919. https://doi.org/10.1177/1464884914549123

Folkenflik, D. (2011, January 4). In London, A Case Study In Opinionated Press. NPR. Retrieved from http://www.npr.org/2011/01/04/132629428/in-london-a-case-studyin-opinionated-press

Gamson, W. A., \& Modigliani, A. (1989). Media Discourse and Public Opinion on Nuclear Power: A Constructionist Approach. American Journal of Sociology, 95(1), $1-37$.

Garland, S. (2014, August 17). Why is a Reagan-era report driving today's education reform? Retrieved August 3, 2017, from http://hechingerreport.org/report-1980sdriving-todays-education-reform/

Gerstl-Pepin, C. I. (2002). Media (Mis)Representations of Education in the 2000 Presidential Election. Educational Policy, 16(1), 37-55. https://doi.org/10.1177/0895904802016001003

Giles, R. H. (2010). New economic models for U.S. journalism. Daedalus, 139(2), 2638.

Goffman, E. (1974). Frame Analysis: An Essay on the Organization of Experience. New York: Harper \& Row.

Goldstein, A. (2016, July 8). When Chalkbeat Needs an "Expert," They Consult Students First NY. Retrieved from http://nyceducator.com/2016/07/when-chalkbeat-needsexpert-they.html

Goldstein, R. A. (2011). Imaging the Frame: Media Representations of Teachers, Their Unions, NCLB, and Education Reform. Educational Policy, 25(4), 543-576. https://doi.org/10.1177/0895904810361720

Gormley, W. T. (2005). The Universal Pre-K Bandwagon. The Phi Delta Kappan, 87(3), 246-249.

Green, E., Cramer, P., \& Anand, A. (2014). What We Talk About When We Talk About Impact: One News Organization's Approach to Practicing Journalism with a 


\section{NEWS FRAMING OF UNIVERSAL PRE-K ROLLOUT IN NYC}

Purpose. Retrieved from http://www.chalkbeat.org/wpcontent/uploads/2016/04/Chalkbeat-White-Paper-on-Impact-042914.pdf

Greenfield, R. (2014, January 7). A Look Inside The Last New York Times Site Redesign Ever. Retrieved April 29, 2017, from https://www.fastcompany.com/3024407/alook-inside-the-last-new-york-times-site-redesign-ever

Haas, E. (2007). False Equivalency: Think Tank References on Education in the News Media. Peabody Journal of Education, 82(1), 63-102.

Hallin, D. C., \& Mancini, P. (2004). Comparing Media Systems: Three Models of Media and Politics. Cambridge University Press.

Hallin, D. C. (1984). The Media, the War in Vietnam, and Political Support: A Critique of the Thesis of an Oppositional Media. The Journal of Politics, 46(1), 2-24. https://doi.org/10.2307/2130432

Heckman, J., Pinto, R., \& Savelyev, P. (2013). Understanding the Mechanisms Through Which an Influential Early Childhood Program Boosted Adult Outcomes. The American Economic Review, 103(6), 2052-2086.

Henson, L. (2017, March 17). Opinion | Why we can't give up funding public broadcasting. Newsweek. Retrieved from http://www.newsweek.com/importancepublic-broadcasting-570007

Hogan, L. (2013). Public schools in crisis: a content analysis of news framing since No Child Left Behind (Thesis). University of Missouri--Columbia. Retrieved from https://mospace.umsystem.edu/xmlui/handle/10355/37951

Hseih, H.-F., \& Shannon, S. E. (2005). Three Approaches to Qualitative Content Analysis. Qualitative Health Research, 15(9), 1277-1288.

Iyengar, S. (1987). Television News and Citizens' Explanations of National Affairs. American Political Science Review, 81(3), 815-831. https://doi.org/10.2307/1962678

Iyengar, S. (1994). Is Anyone Responsible?: How Television Frames Political Issues. University of Chicago Press.

Jacobson, H. K. (1973). Needed Improvements in Education News Coverage as Perceived by Media and Education Gatekeepers. The Journal of Educational Research, 66(6), 274-278. 


\section{NEWS FRAMING OF UNIVERSAL PRE-K ROLLOUT IN NYC}

Jennings, J. (2008, July 31). Introducing Gotham Schools: A New York City Schools Blog! Retrieved from http://blogs.edweek.org/edweek/eduwonkette/2008/07/introducing_gotham_schools a_new_york_city_schools_blog.html?cmp=SOC-SHR-FB

Jensen, E. (2013, December 15). NPR Gets \$17 Million in Grants to Expand Coverage and Develop Digital Platform. The New York Times. Retrieved from http://www.nytimes.com/2013/12/16/business/media/npr-gets-17-million-in-grantsto-expand-coverage-and-develop-digital-platform.html

Jones, T. (2006). The evolution of a beat: a case study of changes in environmental reporting from the 1970's to today as evident in coverage of three disastrous oil spills (Thesis). University of Missouri--Columbia. Retrieved from https://mospace.umsystem.edu/xmlui/handle/10355/6255

Karoly, L. A. (2016). The Economic Returns to Early Childhood Education. The Future of Children, 26(2), 37-55.

Klaidman, S., \& Beauchamp, T. L. (1987). The virtuous journalist. New York: Oxford University Press.

Kline, D., \& Burstein, D. (2005). Blog!: how the newest media revolution is changing politics, business, and culture. New York: CDS Books.

Klinenberg, E. (2005). Convergence: News Production in a Digital Age. The Annals of the American Academy of Political and Social Science, 597, 48-64.

Koger, G., Masket, S., \& Noel, H. (2009). Partisan Webs: Information Exchange and Party Networks. British Journal of Political Science, 39(3), 633-653.

Kowalchuk, L. (2010). Multisectoral Movement Alliances and Media Access: Salvadoran Newspaper Coverage of the Health Care Struggle. Latin American Politics and Society, 52(4), 107-135.

Kunelius, R. (2006). GOOD JOURNALISM: On the evaluation criteria of some interested and experienced actors. Journalism Studies, 7(5), 671-690. https://doi.org/10.1080/14616700600890323

Lacy, S., \& Coulson, D. C. (2000). Comparative Case Study: Newspaper Source Use on the Environmental Beat. Newspaper Research Journal, 21(1), 13-25. https://doi.org/10.1177/073953290002100102 


\section{NEWS FRAMING OF UNIVERSAL PRE-K ROLLOUT IN NYC}

Lewenstein, B. V. (1987). Was There Really a Popular Science "Boom"? Science, Technology, \& Human Values, 12(2), 29-41.

Lewis, A. C. (2004). Spinning the Message on NCLB. The Phi Delta Kappan, 86(4), 260-261.

Macnamara, J. (2016). The Continuing Convergence of Journalism and PR: New Insights for Ethical Practice From a Three-Country Study of Senior Practitioners. Journalism and Mass Communication Quarterly; Columbia, 93(1), 118-141. https://doi.org/http://dx.doi.org.proxy.library.umkc.edu/10.1177/107769901560580 3

Malik, O. (2017, February 20). How is The New York Times Really Doing? Retrieved October 20, 2017, from https://om.co/2017/02/20/how-is-the-new-york-timesreally-doing/

Marcus, J. (2011). Bridging the Great Divide. Academe, 97(3), 14-16.

Matthes, J. (2009). What's in a Frame? A Content Analysis of Media Framing Studies in the World's Leading Communication Journals, 1990-2005. Journalism \& Mass Communication Quarterly, 86(2), 349-367. https://doi.org/10.1177/107769900908600206

Matthews, D. (2013, February 14). READ: Obama's pre-K plan. Retrieved May 20, 2017, from https://www.washingtonpost.com/news/wonk/wp/2013/02/14/readobamas-pre-k-plan/

Mcnergney, R. F. (1990). Improving Communication among Educational Researchers, Policymakers, and the Press. Educational Researcher, 19(3), 20-23. https://doi.org/10.2307/1176067

McQuaid, E. P. (1989). A Story at Risk: The Rising Tide of Mediocre Education Coverage. The Phi Delta Kappan, 70(5), K1-K8.

Mervis, J. (2011). Past Successes Shape Effort To Expand Early Intervention. Science, 333(6045), 952-956.

Mitchell, A., \& Holcomb, J. (2016, June 15). State of the News Media 2016. Retrieved from http://www.journalism.org/2016/06/15/state-of-the-news-media-2016/

Moeller, S. D. (2006). "REGARDING THE PAIN OF OTHERS": MEDIA, BIAS AND THE COVERAGE OF INTERNATIONAL DISASTERS. Journal of International Affairs, 59(2), 173-196. 


\section{NEWS FRAMING OF UNIVERSAL PRE-K ROLLOUT IN NYC}

Molek-Kozakowska, K. (2017). Communicating environmental science beyond academia: Stylistic patterns of newsworthiness in popular science journalism. Discourse \& Communication, 11(1), 69-88. https://doi.org/10.1177/1750481316683294

Morasso, S. G. (2012). Contextual frames and their argumentative implications: A case study in media argumentation. Discourse Studies, 14(2), 197-216.

Moses, M. S. (2007). The Media as Educators, Educational Research, and Autonomous Deliberation. Peabody Journal of Education, 82(1), 150-165.

New York Public Radio Annual Report FY14. (2014). Retrieved from http://www.fy14annualreport.nypublicradio.org/facts-figures/

New York Public Radio Media Kit. (2017). New York Public Radio. Retrieved from https://static1.squarespace.com/static/53ff2c53e4b0e1f6ca3c017d/t/58b720721b10e 3882dcbe980/1488396417423/Media+Kit+Q1+2017.pdf

Peterson, M. A. (2001). Getting to the Story: Unwriteable Discourse and Interpretive Practice in American Journalism. Anthropological Quarterly, 74(4), 201-211.

Pianta, R. C., Barnett, W. S., Burchinal, M., \& Thornburg, K. R. (2009). The Effects of Preschool Education: What We Know, How Public Policy Is or Is Not Aligned With the Evidence Base, and What We Need to Know. Psychological Science in the Public Interest, 10(2), 49-88.

Reich, Z. (2009). Sourcing the news: key issues in journalism--an innovative study of the Israeli press. Cresskill, N.J: Hampton Press.

Rich, M. (2013, February 13). Early Education Far Short of Goal in Obama Speech. The New York Times. Retrieved from http://www.nytimes.com/2013/02/14/education/early-education-far-short-of-goalin-obama-speech.html?pagewanted=all

Robinson, S., \& DeShano, C. (2011). "Anyone can know": Citizen journalism and the interpretive community of the mainstream press. Journalism, 12(8), 963-982. https://doi.org/10.1177/1464884911415973

SchoolBook. (2016). Retrieved April 29, 2017, from http://www.wnyc.org/blogs/schoolbook 


\section{NEWS FRAMING OF UNIVERSAL PRE-K ROLLOUT IN NYC}

Schneider, J. (2016, June 22). America's Not-So-Broken Education System. The Atlantic. Retrieved from https://www.theatlantic.com/education/archive/2016/06/everythingin-american-education-is-broken/488189/

Semetko, H., \& Valkenburg, P. (2000). Framing European politics: a content analysis of press and television news. Journal of Communication, 50(2), 93-109. https://doi.org/10.1111/j.1460-2466.2000.tb02843.x

Shafer, J., \& Doherty, T. (2017, June). The Media Bubble Is Real - And Worse Than You Think. POLITICO Magazine. Retrieved from http://politi.co/2q0ZmYh

Shine, K. (2015). Are Australian Teachers Making The Grade? A Study of News Coverage of NAPLAN Testing. Media International Australia, (154), 25-33.

Staff - Chalkbeat. (n.d.). Retrieved from http://about.chalkbeat.org/team-members/

Steele, J. E. (1995). Experts and the Operational Bias of Television News: The Case of the Persian Gulf War. Journalism \& Mass Communication Quarterly, 72(4), 799812. https://doi.org/10.1177/107769909507200404

Steussy, L. (2016, July 19). How Chalkbeat is trying to build a bigger audience for education news. Columbia Journalism Review. Retrieved from http://www.cjr.org/united_states_project/chalkbeat_education_news_local_sites_nat ional_story.php

Tamir, E., \& Davidson, R. (2011). Staying Above the Fray: Framing and Conflict in the Coverage of Education Policy Debates. American Journal of Education, 117(2), 233-265. https://doi.org/10.1086/657889

Tandoc, E. C., \& Peters, J. (2015). One journalist, two roles: What happens when journalists also work as media coordinators? Journalism, 16(3), 324-340. https://doi.org/10.1177/1464884913520199

Vaughan, K. (2009, January 6). From a GothamSchools original, goodbye and thanks for reading. Retrieved from http://www.chalkbeat.org/posts/ny/2009/01/06/goodbyethank-you-for-reading/

Vercellotti, T., \& Brewer, P. R. (2006). “To Plead Our Own Cause”: Public Opinion Toward Black and Mainstream News Media among African Americans. Journal of Black Studies, 37(2), 231-250. 


\section{NEWS FRAMING OF UNIVERSAL PRE-K ROLLOUT IN NYC}

Walejko, G., \& Ksiazek, T. (2010). BLOGGING FROM THE NICHES: The sourcing practices of science bloggers. Journalism Studies, 11(3), 412-427. https://doi.org/10.1080/14616700903407429

Watson, A. (1998). The Newspaper's Responsibility. The Phi Delta Kappan, 79(10), 728-734.

Wheeler, M. (2008). How Noninstitutionalized Media Change the Relationship between the Public and Media Coverage of Trials. Law and Contemporary Problems, 71(4), $135-153$.

Wong, A. (2014a, November 18). The Case Against Universal Preschool. The Atlantic. Retrieved from https://www.theatlantic.com/education/archive/2014/11/the-caseagainst-universal-preschool/382853/

Wong, A. (2014b, November 19). The Politics of "Pre-K." The Atlantic. Retrieved from https://www.theatlantic.com/education/archive/2014/11/the-politics-of-pre$\mathrm{k} / 382878 /$

Wright, W. E. (2005). The Political Spectacle of Arizona's Proposition 203. Educational Policy, 19(5), 662-700. https://doi.org/10.1177/0895904805278066

Yin, R. K. (2014). Case Study Research Design and Methods (5th ed). Thousand Oaks: Sage Publications. 
NEWS FRAMING OF UNIVERSAL PRE-K ROLLOUT IN NYC

Appendix A - Code Sheet

Identifier:

Headline:

Publication: Publication date: Byline:

Source A

Name: Title:

Affiliation:

Category:

New York City official

New York City Department of Education official

academic/institutionally-affiliated researcher

advocacy organization

classroom teacher

student state official

teachers union

think tank

principal/administrator

parent

other

Source B

Name:

Title:

Affiliation:

Category:
New York City official
New York City Department of Education official academic/institutionally-affiliated researcher
advocacy organization
classroom teacher
student
state official
teachers union
think tank
principal/administrator
parent
other 
NEWS FRAMING OF UNIVERSAL PRE-K ROLLOUT IN NYC

Source C

Name: Title:

Affiliation:

Category:
New York City official
state official
New York City Department of Education official
teachers union
academic/institutionally-affiliated researcher
think tank
advocacy organization
principal/administrator
classroom teacher
parent
student
other

Mark any and all generic news frames present in the article:

$\square$ attribution of responsibility/blame

$\square$ conflict

human interest

economic consequence

morality

Did the story use the language of failing schools to describe the performance of students or otherwise sensationalize pre-K?
yes
no

(If yes, describe:

Note any words or phrases that may be helpful for qualitative analysis: 


\section{NEWS FRAMING OF UNIVERSAL PRE-K ROLLOUT IN NYC}

\section{Appendix B - Code Book}

1) For every article, copy the headline, publication date, and byline. For publication, record Chalkbeat New York as CHALK, The New York Times as NYT, and WNYC as WNYC.

2) For each source, record the source's name, title, and organizational affiliation. If the source is identified as belonging to a political party, this should also be noted. You will not always be able to complete this section. For example, a spokesperson might not be identified by name. Only include sources who have quotes attributed to them.

3) Place the first source that appears in the article into one of the following categories: New York City official, state official (including elected representatives), New York City Department of Education official, teachers union, academic/institutionally-affiliated researcher, think tank, advocacy organization, principal/administrator, classroom teacher, parent, student, or other.

4) Attach additional pages if more than three sources appear in the story.

5) Consider whether any of the five generic news frames - attribution of responsibility, conflict, human interest, economic consequences, and morality - are present in the story by asking yourself the following questions:

a) Attribution of Responsibility: Does the story suggest that someone is responsible for the issue/problem? Does the story suggest that someone has the ability to alleviate the problem? Does the story suggest a solution to the problem? $\square$ Does the story suggest that an individual or a group of people is responsible for the problem? Does the story suggest the problem requires urgent action? Example: "A week before the start of the school year, more than 300 New York City contracts with organizations that will be teaching prekindergarten classes have not been delivered by the city to the comptroller's office for required vetting."

b) Conflict: Does the article reflect disagreement between parties/individuals/groups? Does one party/individual/group reproach another? Does the story refer to two sides or more than two sides of the problem? Does the story refer to winners and losers? Example: "The mayor's office immediately pushed back, arguing to reporters that Mr. Stringer's office was skewing the numbers."

c) Human Interest: Does the story emphasize how individuals and groups are affected by the problem? Does the story provide a human example of the problem? Does the story employ adjectives or personal vignettes? Does the story 


\section{NEWS FRAMING OF UNIVERSAL PRE-K ROLLOUT IN NYC}

go into the private or personal lives of the actors? Does the story contain visual information that might create feelings of outrage, empathy or caring? Example: "The auditorium at Public School 10 in South Slope was thrumming with the sounds of restless children and their anxious chaperones."

d) Economic consequences: Is there a mention of financial losses or gains now or in the future? Is there a mention of the costs/degree of expense involved? Is there a reference to economic consequences of pursuing or not pursuing a course of action? Example: "The tax hasn't been embraced by Cuomo, a Democrat, or state Senate Republicans, and they could be hard to sway in an election year where they are stressing efforts to lower the cost-of-living for New Yorkers."

e) Morality: Does the story contain any moral message? Does the story make reference to morality, God, and other religious tenants? Does the story offer specific social prescriptions about how to behave? Example: "Fuller has written a book arguing that universal pre- $\mathrm{K}$ is misguided because it does not focus only on poor children."

6) Note whether the reporter used any of the following words to describe schools: failing, broken, ineffective, crisis, reform, overhaul, low-achieving, low-performing, underachieving, worst-performing, underperforming, troubled, problem, needs improvement, in need of improvement, falling behind, falling short, falling apart, struggling, or lagging behind. Likewise, note any particularly dramatic language that served to sensationalize or exaggerate the story, or words that otherwise make a value judgment.

7) Finally, note anything about the article worthy of further analysis. Some questions to consider:

a) Did the headline accurately reflect what the article was about?

b) Did the reporter provide enough detail about the organizational or institutional affiliation of a source to make clear their position?

c) Did the reporter adequately explain education terminology and jargon?

d) Was any one source given a greater platform than others?

e) Were any words or phrases particularly salient?

f) Did the article leave anything out, or was it missing an important perspective? 
NEWS FRAMING OF UNIVERSAL PRE-K ROLLOUT IN NYC

\section{Appendix C - Chalkbeat Articles Collected for Analysis}

Cramer, P. (2014a, January 1). De Blasio's inaugural address features pre-K plan heavily. Retrieved from http://www.chalkbeat.org/posts/ny/2014/01/01/de-blasiosinaugural-address-features-pre-k-plan-heavily/

Cramer, P. (2014b, January 27). De Blasio unveils implementation plan for lofty pre-K proposal. Retrieved from http://www.chalkbeat.org/posts/ny/2014/01/27/de-blasiounveils-implementation-plan-for-lofty-pre-k-proposal/

Cramer, P. (2014c, January 27). De Blasio's state budget testimony centers on pre-K plan. Retrieved from http://www.chalkbeat.org/posts/ny/2014/01/27/de-blasiosstate-budget-testimony-centers-on-pre-k-plan/

Cramer, P. (2014d, January 31). Pre-K in and charter schools out in de Blasio school construction plan. Retrieved from

http://www.chalkbeat.org/posts/ny/2014/01/31/pre-k-in-and-charter-schools-out-inde-blasio-school-construction-plan/

Cramer, P. (2014e, February 10). Legislators squabbling over whether to vote on de Blasio pre-K tax plan. Retrieved from http://www.chalkbeat.org/posts/ny/2014/02/10/legislators-squabbling-overwhether-to-vote-on-de-blasio-pre-k-tax-plan/

Cramer, P. (2014f, February 10). Lots of pre-K, but little education news, in de Blasio address. Retrieved from http:/www.chalkbeat.org/posts/ny/2014/02/10/lots-of-prek-but-little-education-news-in-de-blasio-address/

Cramer, P. (2014g, February 12). Children's Aid alum to head education department's pre-K efforts. Retrieved from http://www.chalkbeat.org/posts/ny/2014/02/12/childrens-aid-alum-to-headeducation-departments-pre-k-efforts/

Cramer, P. (2014h, March 7). De Blasio recruits parent bloggers in pre-K push. Retrieved from http://www.chalkbeat.org/posts/ny/2014/03/07/de-blasio-recruits-parentbloggers-in-pre-k-push/

Cramer, P. (2014i, March 10). City officials soften tone on pre-K funding, Success standoff. Retrieved from http://www.chalkbeat.org/posts/ny/2014/03/10/cityofficials-soften-tone-on-pre-k-funding-success-standoff/ 


\section{NEWS FRAMING OF UNIVERSAL PRE-K ROLLOUT IN NYC}

Cramer, P. (2014j, March 17). What de Blasio says when he talks to parents about pre-K. Retrieved from http://www.chalkbeat.org/posts/ny/2014/03/17/what-de-blasio-sayswhen-he-talks-to-parents-about-pre-k/

Cramer, P. (2014k, August 1). What We're Reading: An argument for seeing pre-K as a means, not an end. Retrieved from

http://www.chalkbeat.org/posts/ny/2014/08/01/what-were-reading-as-argument-forseeing-pre-k-as-a-means-not-an-end/

Cramer, P. (2014l, September 5). What We're Reading: Pre-K to become a federal school turnaround strategy. Retrieved from http://www.chalkbeat.org/posts/ny/2014/09/05/what-were-reading-pre-k-tobecome-a-federal-school-turnaround-strategy-3/

Cramer, P., \& Darville, S. (2014, January 21). Heading to Bank Street, PolakowSuransky is first to exit Fariña's ed department. Retrieved from http://www.chalkbeat.org/posts/ny/2014/01/21/heading-to-bank-street-polakowsuransky-is-first-to-exit-farinas-ed-department/

Cummings, M. (2014, August 25). As city seeks out new pre-K teachers, a training challenge grows. Retrieved from http://www.chalkbeat.org/posts/ny/2014/08/25/ascity-seeks-out-new-pre-k-teachers-a-training-challenge-grows/

Darville, S. (2014a, January 28). To implement de Blasio's pre-K plan, Dept. of Education faces a formidable to-do list. Retrieved from http:/www.chalkbeat.org/posts/ny/2014/01/28/to-implement-de-blasios-pre-k-plandept-of-education-faces-a-formidable-to-do-list/

Darville, S. (2014b, February 4). Children's Aid CEO tapped to lead city's pre-K, community schools efforts. Retrieved from http://www.chalkbeat.org/posts/ny/2014/02/04/childrens-aid-ceo-tapped-to-leadcitys-pre-k-community-schools-efforts/

Darville, S. (2014c, February 10). After 23 years, Canada stepping down as Harlem Children's Zone CEO. Retrieved from http://www.chalkbeat.org/posts/ny/2014/02/10/after-23-years-canada-steppingdown-as-harlem-childrens-zone-ceo/

Darville, S. (2014d, February 11). Fariña offers more support for pre-K, but no new details on charters or teacher pay. Retrieved from http://www.chalkbeat.org/posts/ny/2014/02/11/farina-offers-more-support-for-prek-but-no-new-details-on-charters-or-teacher-pay/ 


\section{NEWS FRAMING OF UNIVERSAL PRE-K ROLLOUT IN NYC}

Darville, S. (2014e, February 25). De Blasio: We have the space for pre-K-and now we need the money. Retrieved from http://www.chalkbeat.org/posts/ny/2014/02/25/deblasio-we-have-the-space-for-pre-k-and-now-we-need-the-money/

Darville, S. (2014f, February 25). Fariña: Principals have already offered 800 classrooms for pre-K. Retrieved from http://www.chalkbeat.org/posts/ny/2014/02/25/farinaprincipals-have-already-offered-800-classrooms-for-pre-k/

Darville, S. (2014g, March 21). Pre-K recruitment site to help connect teachers and community organizations. Retrieved from http://www.chalkbeat.org/posts/ny/2014/03/21/pre-k-recruitment-site-to-helpconnect-teachers-and-community-organizations/

Darville, S. (2014h, April 24). Applications for school-based pre-K up 36 percent, city says. Retrieved from http://www.chalkbeat.org/posts/ny/2014/04/24/applicationsfor-school-based-pre-k-up-36-percent-city-says/

Decker, G. (2014a, January 6). Once a skeptic, Mulgrew endorses Mayor de Blasio's preK tax. Retrieved from http://www.chalkbeat.org/posts/ny/2014/01/06/once-askeptic-mulgrew-endorses-mayor-de-blasios-pre-k-tax/

Decker, G. (2014b, January 15). Cuomo commission endorses charter schools for pre-K. Retrieved from http://www.chalkbeat.org/posts/ny/2014/01/14/charter-schools-getpre-k-endorsement-from-cuomo-commission/

Decker, G. (2014c, January 15). De Blasio leaves the door open for charter pre-K's. Retrieved from http://www.chalkbeat.org/posts/ny/2014/01/15/facing-competingcampaign-issues-de-blasio-signals-openness-to-charter-pre-ks/

Decker, G. (2014d, January 22). Cuomo budget: Funds for pre-K, technology, and merit pay. Retrieved from http://www.chalkbeat.org/posts/ny/2014/01/21/cuomo-budgetfunds-for-pre-k-technology-and-merit-pay/

Decker, G. (2014e, January 27). During hearing, de Blasio's pre-K gatekeepers scrutinize his plan. Retrieved from http://www.chalkbeat.org/posts/ny/2014/01/27/duringhearing-de-blasios-pre-k-gatekeepers-scrutinize-his-plan/

Decker, G. (2014f, January 28). In first budget testimony, Fariña echoes call for de Blasio's pre-K tax. Retrieved from http://www.chalkbeat.org/posts/ny/2014/01/28/in-first-budget-testimony-farinaechoes-call-for-de-blasios-pre-k-tax/

Decker, G. (2014g, January 28). King says statewide pre-K would cost far more than Cuomo budgeted. Retrieved from 


\section{NEWS FRAMING OF UNIVERSAL PRE-K ROLLOUT IN NYC}

http://www.chalkbeat.org/posts/ny/2014/01/28/king-says-statewide-pre-kexpansion-would-cost-far-more-than-cuomo-budgeted/

Decker, G. (2014h, March 4). Cuomo touts charter schools in surprise rally appearance, clouding de Blasio's pre-K lobby day. Retrieved from http://www.chalkbeat.org/posts/ny/2014/03/04/cuomo-touts-charter-schools-insurprise-rally-appearance-clouding-de-blasios-pre-k-lobby-day/

Decker, G. (2014i, March 9). City schools boss preaches pre-K at church congregation. Retrieved from http://www.chalkbeat.org/posts/ny/2014/03/09/city-schools-bosspreaches-pre-k-at-church-congregation/

Decker, G. (2014j, March 12). Assembly spending plan includes statewide pre-K funds, extra $\$ 1$ billion for schools. Retrieved from http://www.chalkbeat.org/posts/ny/2014/03/12/assembly-spending-plan-includesstatewide-pre-k-funds-extra-1-billion-for-schools/

Decker, G. (2014k, March 29). Pre-K funds, charter school protections, and Common Core changes in state budget deal. Retrieved from http://www.chalkbeat.org/posts/ny/2014/03/29/charter-school-protections-pre-kfunds-and-common-core-changes-part-state-budget-deal/

Decker, G. (20141, April 3). At pre-K event, Silver reminds de Blasio: Don't forget classroom trailers. Retrieved from http://www.chalkbeat.org/posts/ny/2014/04/03/at-pre-k-event-silver-reminds-deblasio-dont-forget-classroom-trailers/

Decker, G. (2014m, April 3). With state funding secure, Mayor de Blasio announces locations of new school pre-K programs. Retrieved from http://www.chalkbeat.org/posts/ny/2014/04/02/with-state-funding-secure-mayor-deblasio-announces-locations-of-new-school-pre-k-programs/

Decker, G. (2014n, April 28). City hurrying to allow charter schools to open pre-K programs, but big questions remain. Retrieved from http:/www.chalkbeat.org/posts/ny/2014/04/28/city-hurrying-to-allow-charterschools-to-open-pre-k-programs-but-big-questions-remain/

Decker, G. (2014o, April 28). In Albany, officials wave pre-K warning flags for New York City. Retrieved from http://www.chalkbeat.org/posts/ny/2014/04/28/inalbany-officials-wave-pre-k-warning-flags-for-new-york-city/

Decker, G. (2014p, May 28). Eleven charter schools vie to help de Blasio launch pre-K, with some anxiety. Retrieved from 


\section{NEWS FRAMING OF UNIVERSAL PRE-K ROLLOUT IN NYC}

http://www.chalkbeat.org/posts/ny/2014/05/28/eleven-charter-schools-vie-to-helpde-blasio-launch-pre-k-with-some-anxiety/

Decker, G. (2014q, August 28). Stringer: 70 percent of pre-K contracts haven't been vetted. Retrieved from http://www.chalkbeat.org/posts/ny/2014/08/27/stringer-70percent-of-pre-k-contracts-havent-been-vetted/

Decker, G. (2014r, August 29). Education leaders urge patience for de Blasio's pre-K plans. Retrieved from http://www.chalkbeat.org/posts/ny/2014/08/28/educationleaders-urge-patience-for-de-blasios-pre-k-plans/

Decker, G. (2014s, November 5). Voters greenlight $\$ 780$ million for pre-K construction, trailer removal. Retrieved from http://www.chalkbeat.org/posts/ny/2014/11/05/voters-greenlight-780-million-forpre-k-construction-classroom-trailer-removal/

Decker, G. (2014t, November 13). 1,700 late enrollees push city pre-K enrollment over de Blasio's goal. Retrieved from http://www.chalkbeat.org/posts/ny/2014/11/12/1700-late-enrollees-push-city-pre-kenrollment-over-de-blasios-goal/

Glazer, J. (2014a, July 11). City plans Bank Street teacher training ahead of fall pre-K push. Retrieved from http://www.chalkbeat.org/posts/ny/2014/07/11/city-plansbank-street-teacher-training-ahead-of-fall-pre-k-push/

Glazer, J. (2014b, July 24). At a homeless shelter, a pre-K program almost like any other. Retrieved from http://www.chalkbeat.org/posts/ny/2014/07/24/at-a-homelessshelter-a-pre-k-program-almost-like-any-other/

Glazer, J. (2014c, August 13). As the first day of school approaches, the city trains thousands of universal pre-K teachers. Retrieved from http://www.chalkbeat.org/posts/ny/2014/08/12/as-the-first-day-of-schoolapproaches-the-city-trains-thousands-of-universal-pre-k-teachers/

Glazer, J. (2014d, August 22). After combined effort, city agencies say health violations at pre-K sites are down. Retrieved from http://www.chalkbeat.org/posts/ny/2014/08/22/after-combined-effort-city-agenciessay-health-violations-at-pre-k-sites-are-down/

Glazer, J. (2014e, August 28). Most pre-K seats are full one week before the start of school, city says. Retrieved from http://www.chalkbeat.org/posts/ny/2014/08/28/most-of-the-citys-pre-k-seats-arefilled-one-week-before-the-start-of-school-city-says/ 


\section{NEWS FRAMING OF UNIVERSAL PRE-K ROLLOUT IN NYC}

Glazer, J. (2014f, September 2). Nine pre-K sites won't open because of safety concerns. Retrieved from http://www.chalkbeat.org/posts/ny/2014/09/02/nine-pre-k-siteswont-open-because-of-safety-concerns/

Glazer, J. (2014g, October 8). After study questions equity of pre-K expansion, city pushes back. Retrieved from http://www.chalkbeat.org/posts/ny/2014/10/07/afterstudy-questions-equity-of-pre-k-expansion-city-pushes-back/

Glazer, J., \& Wall, P. (2014, September 4). Thousands of four-year-olds help de Blasio fulfill pre-K goal. Retrieved from http://www.chalkbeat.org/posts/ny/2014/09/04/thousands-of-four-year-olds-helpde-blasio-fulfill-pre-k-goals/

McIntire, M. E. (2014a, June 5). 62 percent of applicants get a public-school pre-K match, but many left waiting. Retrieved from http://www.chalkbeat.org/posts/ny/2014/06/05/62-percent-of-applicants-get-apublic-school-pre-k-match/

McIntire, M. E. (2014b, July 11). Six charter schools now making final plans to launch pre-K this fall. Retrieved from http://www.chalkbeat.org/posts/ny/2014/07/11/sixcharter-schools-now-making-final-plans-to-launch-pre-k-this-fall/

Neuwirth, R. (2014, March 20). What my family got out of daycare that public pre-K could provide. Retrieved from http://www.chalkbeat.org/posts/ny/2014/03/20/whatmy-family-got-out-of-daycare-that-public-pre-k-could-provide/

Schechter, J. (2014a, June 4). De Blasio defends quality of community-based pre-K sites. Retrieved from http://www.chalkbeat.org/posts/ny/2014/06/03/de-blasio-defendsquality-of-community-based-pre-k-sites/

Schechter, J. (2014b, August 5). At national summit, Fariña says she will keep "stress factor" out of pre-K. Retrieved from http://www.chalkbeat.org/posts/ny/2014/08/05/at-national-summit-farina-says-shewill-keep-stress-factor-out-of-pre-k/

Schechter, J. (2014c, August 6). Two half-day pre-K programs do not a full day make, policy brief says. Retrieved from http://www.chalkbeat.org/posts/ny/2014/08/06/two-half-day-pre-k-programs-donot-a-full-day-make-policy-brief-says/

Schechter, J., \& Wall, P. (2014, June 12). In pursuit of pre-K goal, city goes to great lengths to enlist yeshivas. Retrieved from http://www.chalkbeat.org/posts/ny/2014/06/12/in-pursuit-of-pre-k-goal-city-goesto-great-lengths-to-enlist-yeshivas/ 


\section{NEWS FRAMING OF UNIVERSAL PRE-K ROLLOUT IN NYC}

Snyder, S. (2014, December 2). What defined 2014 for Chalkbeat readers? Pre-K, a new contract, and some successful students. Retrieved from http://www.chalkbeat.org/posts/ny/2014/12/02/what-defined-2014-for-chalkbeatreaders-pre-k-a-new-contract-and-some-successful-students/

Sokoloff-Rubin, E. (2014a, May 27). A birds-eye view of every public school pre-K seat in the city. Retrieved from http://www.chalkbeat.org/posts/ny/2014/05/27/a-birdseye-view-of-every-public-school-pre-k-seat-in-the-city/

Sokoloff-Rubin, E. (2014b, June 4). In separate special education system for pre-K, principals see hurdles they expect will grow. Retrieved from http://www.chalkbeat.org/posts/ny/2014/06/04/in-separate-special-educationsystem-for-pre-k-principals-see-hurdles-they-expect-will-grow/

Sokoloff-Rubin, E. (2014c, June 11). Across elementary schools, an array of motives for adding pre-K seats. Retrieved from

http://www.chalkbeat.org/posts/ny/2014/06/11/across-elementary-schools-an-arrayof-motives-for-adding-pre-k-seats/

Sokoloff-Rubin, E. (2014d, August 12). Buery defends pre-K guidelines issued to religious schools. Retrieved from

http://www.chalkbeat.org/posts/ny/2014/08/12/buery-defends-pre-k-guidelinesissued-to-religious-schools/

Sokoloff-Rubin, E. (2014e, August 19). With day one fast approaching, de Blasio and Fariña rally pre-K teachers. Retrieved from http://www.chalkbeat.org/posts/ny/2014/08/19/with-day-one-fast-approaching-deblasio-and-farina-rally-pre-k-teachers/

Sokoloff-Rubin, E. (2014f, August 26). Are principals prepared to evaluate pre-K teachers? Retrieved from http://www.chalkbeat.org/posts/ny/2014/08/26/areprincipals-prepared-to-evaluate-pre-k-teachers/

Wall, P. (2014a, February 6). In teacher pay gap, another obstacle for de Blasio's pre-K plan. Retrieved from http://www.chalkbeat.org/posts/ny/2014/02/06/in-teacher-paygap-another-obstacle-for-de-blasios-pre-k-plan/

Wall, P. (2014b, March 4). With funding uncertain, city pushes back pre-K enrollment deadline. Retrieved from http://www.chalkbeat.org/posts/ny/2014/03/03/withfunding-uncertain-city-pushes-back-pre-k-enrollment-deadline/ 


\section{NEWS FRAMING OF UNIVERSAL PRE-K ROLLOUT IN NYC}

Wall, P. (2014c, March 25). City plans Teaching Fellows-inspired program for pre-K teachers. Retrieved from http://www.chalkbeat.org/posts/ny/2014/03/25/city-plansteaching-fellows-inspired-program-for-pre-k-teachers/

Wall, P. (2014d, April 14). City aims to close pre-K teacher pay gap with salary hikes. Retrieved from http://www.chalkbeat.org/posts/ny/2014/04/14/city-aims-to-closepre-k-teacher-pay-gap-with-salary-hikes/

Wall, P. (2014e, May 30). City approves 10,400 new pre-K seats in sites across the city. Retrieved from http://www.chalkbeat.org/posts/ny/2014/05/30/city-approves10400-new-pre-k-seats-in-sites-across-the-city/

Wall, P. (2014f, September 23). Classes have started, but some struggling schools still await clear guidance from the city. Retrieved April 16, 2017, from http://www.chalkbeat.org/posts/ny/2014/09/22/classes-have-started-but-somestruggling-schools-still-await-clear-guidance-from-the-city/ 


\section{NEWS FRAMING OF UNIVERSAL PRE-K ROLLOUT IN NYC}

\section{Appendix D - New York Times Articles Collected for Analysis}

Baker, A. (2014a, February 25). De Blasio Says New York Can Add 29,000 Pre-K Seats. The New York Times. Retrieved from https://www.nytimes.com/2014/02/26/nyregion/new-york-city-can-add-29000seats-for-pre-k-mayor-says.html

Baker, A. (2014b, March 7). Pre-K Special Education Contractor Pleads Guilty to Fraud Charge. The New York Times. Retrieved from https://www.nytimes.com/2014/03/08/nyregion/pre-k-special-education-contractorpleads-guilty-to-fraud-charge.html

Baker, A. (2014c, June 5). Less Than Half of New York City's Applicants for Pre-K Get Their Top-Choice School. The New York Times. Retrieved from https://www.nytimes.com/2014/06/06/nyregion/in-pre-k-expansion-fewer-thanhalf-of-city-students-get-top-choice-school.html

Baker, A., \& Hernández, J. C. (2014, March 4). De Blasio and Operator of Charter School Empire Do Battle. The New York Times. Retrieved from https://www.nytimes.com/2014/03/05/nyregion/de-blasio-and-builder-of-charterschool-empire-do-battle.html

Bellafante, G. (2014a, February 27). A Community Center as DMZ in City's Class War. The New York Times. Retrieved from https:/www.nytimes.com/2014/03/02/nyregion/a-community-center-for-allincome-levels.html

Bellafante, G. (2014b, September 4). As Prekindergarten Expands in New York City, Guiding Guided Play. The New York Times. Retrieved from https://www.nytimes.com/2014/09/07/nyregion/as-prekindergarten-expands-innew-york-city-guiding-guided-play.html

Chozick, A. (2014, January 1). With Clintons in His Corner, de Blasio Bolsters Ties to His Party's “Gold Standard." The New York Times. Retrieved from https://www.nytimes.com/2014/01/02/nyregion/with-clintons-in-his-corner-deblasio-bolsters-ties-to-his-partys-gold-standard.html

Craig, S. (2014, February 16). De Blasio Strikes Conciliatory Note on Pre-K. The New York Times. Retrieved from https://www.nytimes.com/2014/02/17/nyregion/mayorstrikes-conciliatory-note-on-pre-k.html

Craig, S., \& Mckinley, J. (2014, January 8). In Speech, Cuomo Pledges Lower Taxes and Statewide Pre-K. The New York Times. Retrieved from 


\section{NEWS FRAMING OF UNIVERSAL PRE-K ROLLOUT IN NYC}

https://www.nytimes.com/2014/01/09/nyregion/cuomo-in-state-of-state-speechunveils-tax-cuts-and-pre-k-pledge.html

Craig, T. K., Susanne, \& Grynbaum, M. M. (2014, March 6). Cuomo Burnishes His Political Brand, Using de Blasio as His Foil. The New York Times. Retrieved from https://www.nytimes.com/2014/03/06/nyregion/cuomo-burnishes-his-politicalbrand-using-de-blasio-as-his-foil.html

Dwyer, J. (2014a, February 13). In Debate Over Paying for Pre-K, Little Agreement Aside From the Goal. The New York Times. Retrieved from https://www.nytimes.com/2014/02/14/nyregion/in-debate-over-paying-for-pre-klittle-agreement-aside-from-the-goal.html

Dwyer, J. (2014b, March 13). No Easy Task in Bid to Find Seats for Pre-K. The New York Times. Retrieved from https://www.nytimes.com/2014/03/14/nyregion/noeasy-task-in-bid-to-find-seats-for-pre-k.html

Flegenheimer, M. (2014, October 2). Questions Raised by Pre-K Video Sent to de Blasio Campaign Supporters. The New York Times. Retrieved from https://www.nytimes.com/2014/10/03/nyregion/questions-raised-by-a-mayoral-prek-video-sent-to-de-blasio-campaign-supporters.html

Grynbaum, M. M. (2014a, January 1). Taking Office, de Blasio Vows to Fix Inequity. The New York Times. Retrieved from https:/www.nytimes.com/2014/01/02/nyregion/bill-de-blasio-inauguration.html

Grynbaum, M. M. (2014b, April 8). Pre-K Victory Ad With Mayor de Blasio's Family Aims to Help Him Regain His Footing. The New York Times. Retrieved from https://www.nytimes.com/2014/04/09/nyregion/pre-k-victory-ad-with-mayor-deblasios-family-aims-to-help-him-regain-his-footing.html

Grynbaum, M. M., \& Craig, S. (2014, January 6). Clash of Priorities Sets Up Cuomo-de Blasio Showdown on Pre-K Push. The New York Times. Retrieved from https://www.nytimes.com/2014/01/07/nyregion/clash-of-priorities-sets-up-cuomode-blasio-showdown-on-pre-k-push.html

Grynbaum, M. M., \& Kaplan, T. (2014a, January 21). Pre-K Plan Puts Cuomo at Odds With de Blasio on Funding. The New York Times. Retrieved from https:/www.nytimes.com/2014/01/22/nyregion/cuomo-prekindergartenproposal.html

Grynbaum, M. M., \& Kaplan, T. (2014b, March 30). De Blasio Betting on Pre-K to Succeed. The New York Times. Retrieved from 


\section{NEWS FRAMING OF UNIVERSAL PRE-K ROLLOUT IN NYC}

https://www.nytimes.com/2014/03/31/nyregion/de-blasio-betting-on-pre-k-tosucceed.html

Harris, E. A. (2014a, August 26). Parents Scramble for Pre-K Seats in Brooklyn District. The New York Times. Retrieved from https://www.nytimes.com/2014/08/27/nyregion/parents-scramble-for-pre-k-seatsin-brooklyn-district.html

Harris, E. A. (2014b, September 3). Final Touches Range From Flowery to Frantic as Expanded Pre-K Awaits Start. The New York Times. Retrieved from https://www.nytimes.com/2014/09/04/nyregion/final-touches-range-from-floweryto-frantic-as-expanded-pre-k-awaits-start.html

Harris, E. A. (2014c, November 6). Manhattan Preschool Teacher Who Alleged Abuse Sues Over Firing. The New York Times. Retrieved from https:/www.nytimes.com/2014/11/07/nyregion/manhattan-preschool-teacher-whoclaimed-co-worker-abused-students-sues-over-firing.html

Harris, E. A., \& Taylor, K. (2014, September 4). 51,000 Answer de Blasio’s Bell for New Pre-K. The New York Times. Retrieved from https://www.nytimes.com/2014/09/05/nyregion/expanded-pre-k-kicks-off-as-newyork-students-head-back-to-school.html

Hernández, J. C. (2014a, January 16). De Blasio, a Critic of Charter Schools, May Need Them for His Pre-K Agenda. The New York Times. Retrieved from https://www.nytimes.com/2014/01/17/nyregion/de-blasio-a-critic-of-charterschools-may-need-them-for-his-pre-k-agenda.html

Hernández, J. C. (2014b, January 26). Lessons for de Blasio in New Jersey’s Free Pre-K. The New York Times. Retrieved from https:/www.nytimes.com/2014/01/27/nyregion/to-expand-prekindergarten-newyork-may-find-model-in-new-jersey.html

Hernández, J. C. (2014c, January 28). Estimate for Statewide Pre-K in New York Puts Schools Chief in a Tangle. The New York Times. Retrieved from https://www.nytimes.com/2014/01/29/nyregion/estimate-for-statewide-pre-k-putsschools-chief-in-a-tangle.html

Hernández, J. C. (2014d, January 31). Funds Meant for Charters May Be Diverted to PreK. The New York Times. Retrieved from https://www.nytimes.com/2014/02/01/nyregion/funds-meant-for-charters-may-bediverted-to-pre-k.html 


\section{NEWS FRAMING OF UNIVERSAL PRE-K ROLLOUT IN NYC}

Hernández, J. C. (2014e, February 10). Chief of Harlem Children’s Program Will Step Aside. The New York Times. Retrieved from

https:/www.nytimes.com/2014/02/11/nyregion/chief-of-harlem-childrens-programwill-step-aside.html

Hernández, J. C. (2014f, March 6). De Blasio and Dolan Announce a Push for More PreK Classes. The New York Times. Retrieved from https:/www.nytimes.com/2014/03/07/nyregion/de-blasio-and-dolan-announce-apush-for-more-pre-k-classes.html

Hernández, J. C. (2014g, April 24). Pre-K Applicants Up 36\% This Year; Mayor's Challenge Is Finding Seats. The New York Times. Retrieved from https://www.nytimes.com/2014/04/25/nyregion/pre-k-applicants-up-36-this-yearmayors-challenge-is-finding-seats.html

Hernández, J. C. (2014h, July 23). At Manhattan Preschool, Accounts of Sex Abuse Case Differ. The New York Times. Retrieved from https://www.nytimes.com/2014/07/24/nyregion/anger-at-a-manhattan-preschoolover-sexual-abuse-accusations-.html

Hernández, J. C., \& Kaplan, T. (2014, March 14). Mayor's Pre-K Tax Drive: Views Vary on Its Success as Widely as on Its Merits. The New York Times. Retrieved from https://www.nytimes.com/2014/03/15/nyregion/mayors-pre-k-tax-drive-views-varyon-its-success-as-widely-as-on-its-merits.html

Hernández, J. C., \& Stewart, N. (2014, February 7). De Blasio Tests Political Might in Pre-K Push. The New York Times. Retrieved from https://www.nytimes.com/2014/02/08/nyregion/de-blasio-tests-political-might-inpre-k-push.html

Ishayik, E. (2014, June 29). Amid de Blasio’s Pre-K Push, a Bid to Boost Learning at a Weak Point in the Pipeline. The New York Times. Retrieved from https://www.nytimes.com/2014/06/30/nyregion/amid-bill-de-blasios-pre-k-push-abid-to-boost-learning-at-a-weak-point-in-the-pipeline.html

Kaplan, T. (2014a, January 20). Cuomo’s Budget Is Said to Include Ethics and Campaign Finance Reforms. The New York Times. Retrieved from https://www.nytimes.com/2014/01/20/nyregion/cuomos-budget-is-said-to-includeethics-and-campaign-finance-reforms.html

Kaplan, T. (2014b, January 23). Cuomo Sweetens Pre-K Deal: "Whatever” Mayor Needs. The New York Times. Retrieved from https://www.nytimes.com/2014/01/23/nyregion/cuomo-sweetens-pre-k-dealwhatever-mayor-needs.html 


\section{NEWS FRAMING OF UNIVERSAL PRE-K ROLLOUT IN NYC}

Kaplan, T. (2014c, February 12). Survey Suggests Voters Prefer Cuomo's Proposal for Pre-K. The New York Times. Retrieved from https://www.nytimes.com/2014/02/13/nyregion/poll-suggests-new-yorkers-favorcuomos-pre-k-plan.html

Kaplan, T. (2014d, August 4). Cuomo Aides Use Allies to Shore Up the Governor's Image. The New York Times. Retrieved from https://www.nytimes.com/2014/08/05/nyregion/cuomo-aides-use-allies-to-shoreup-the-governors-image.html

Kaplan, T., \& Baker, A. (2014, March 13). De Blasio Closes In on Pre-K Funding, but Not From a Higher Tax. The New York Times. Retrieved from https:/www.nytimes.com/2014/03/14/nyregion/mayor-closes-in-on-pre-k-fundingbut-not-with-tax-increase.html

Kaplan, T., \& Hernández, J. C. (2014a, January 27). De Blasio, on Cuomo’s Turf, Stands By Pre-K Strategy. The New York Times. Retrieved from https:/www.nytimes.com/2014/01/28/nyregion/in-albany-de-blasio-seeks-approvalfor-pre-k-tax-plan.html

Kaplan, T., \& Hernández, J. C. (2014b, March 29). State Budget Deal Reached; \$300 Million for New York City Pre-K. The New York Times. Retrieved from https://www.nytimes.com/2014/03/30/nyregion/cuomo-new-york-state-budget.html

Mckinley Jr, J. C. M. (2014, November 13). Sexual Abuse Case Dropped Against Intern at Preschool. The New York Times. Retrieved from https://www.nytimes.com/2014/11/14/nyregion/criminal-charges-are-droppedagainst-intern-at-manhattan-preschool.html

Otterman, S. (2014, August 4). De Blasio's Prekindergarten Expansion Collides With Church-State Divide. The New York Times. Retrieved from https://www.nytimes.com/2014/08/05/nyregion/de-blasios-pre-k-push-bumps-upagainst-church-state-divide.html

Powell, M. (2014a, January 3). De Blasio's Next Task Is Turning Passion Into Policy. The New York Times. Retrieved from https://www.nytimes.com/2014/01/05/nyregion/de-blasios-next-task-is-turningpassion-into-policy.html

Powell, M. (2014b, January 23). Governor Says It's All Settled but the Money. The New York Times. Retrieved from https://www.nytimes.com/2014/01/23/nyregion/governor-says-its-all-settled-butthe-money.html 


\section{NEWS FRAMING OF UNIVERSAL PRE-K ROLLOUT IN NYC}

Powell, M. (2014c, February 12). For de Blasio, No Magic Lost in Budget Draft. The New York Times. Retrieved from https:/www.nytimes.com/2014/02/13/nyregion/for-de-blasio-no-magic-lost-inbudget-draft.html

Powell, M. (2014d, April 2). A Victory, and a Knife in the Side. The New York Times. Retrieved from https://www.nytimes.com/2014/04/03/nyregion/a-victory-and-aknife-in-the-side.html

Powell, M. (2014e, May 28). At a Jewish Gala, de Blasio Skips His Cue to Speak Out. The New York Times. Retrieved from https://www.nytimes.com/2014/05/29/nyregion/at-a-jewish-gala-de-blasio-skipshis-cue-to-speak-out.html

Preschool Director Is Sentenced to Two Years in Prison. (2014, September 4). The New York Times. Retrieved from https:/www.nytimes.com/2014/09/05/nyregion/preschool-director-is-sentenced-totwo-years-in-prison.html

Santora, M. (2014, March 4). Cuomo Vows to Defend Charter Schools, Setting Up Another Battle With de Blasio. The New York Times. Retrieved from https:/www.nytimes.com/2014/03/05/nyregion/cuomo-vows-to-defend-charterschools-setting-up-another-battle-with-de-blasio.html

Schlossberg, T. (2014a, August 14). One Child Recalls Being Touched by Intern at Manhattan Preschool, Prosecutors Say. The New York Times. Retrieved from https://www.nytimes.com/2014/08/15/nyregion/one-child-recalls-being-touched-bya-school-intern.html

Schlossberg, T. (2014b, September 18). Restrictions Are Eased for Ex-Preschool Intern Accused of Sex Abuse. The New York Times. Retrieved from https://www.nytimes.com/2014/09/19/nyregion/restrictions-are-eased-for-expreschool-intern-accused-of-sex-abuse.html

Spencer, K. (2014, July 8). As New York City Expands Pre-K, Private Programs Fear Teacher Drain. The New York Times. Retrieved from https:/www.nytimes.com/2014/07/09/nyregion/community-preschools-sufferteacher-drain-as-city-offers-more-jobs.html

Stewart, N. (2014a, January 23). De Blasio Urges Mayors to Forge an "Urban Consensus." The New York Times. Retrieved from https:/www.nytimes.com/2014/01/24/nyregion/de-blasio-urges-mayors-to-forgean-urban-consensus.html 


\section{NEWS FRAMING OF UNIVERSAL PRE-K ROLLOUT IN NYC}

Stewart, N. (2014b, March 19). Familiar Consultants Hired by de Blasio's Pre-K Drive. The New York Times. Retrieved from

https://www.nytimes.com/2014/03/20/nyregion/familiar-consultants-hired-by-themayors-pre-k-drive.html

Stewart, N. (2014c, May 9). The Women of New York's City Hall. The New York Times. Retrieved from https://www.nytimes.com/2014/05/11/nyregion/the-women-of-newyorks-city-hall.html

Stewart, N. (2014d, August 11). Task Force of Mayors Addresses Income Gap. The New York Times. Retrieved from https:/www.nytimes.com/2014/08/11/nyregion/taskforce-of-mayors-addresses-income-gap.html

Stewart, N. (2014e, August 27). New York Comptroller Is Concerned Over Pre-K Contract Delays. The New York Times. Retrieved from https://www.nytimes.com/2014/08/28/nyregion/new-york-comptroller-isconcerned-over-pre-k-contract-delays.html

Swarns, R. L. (2014a, March 9). Among de Blasio's Priorities, Minimum Wage Waits Behind Pre-K. The New York Times. Retrieved from https://www.nytimes.com/2014/03/10/nyregion/among-de-blasios-prioritiesminimum-wage-waits-behind-pre-k.html

Swarns, R. L. (2014b, July 20). A Parent Answering a Call for Pre-K Teachers Goes Back to Work (and School). The New York Times. Retrieved from https://www.nytimes.com/2014/07/21/nyregion/a-parent-answering-a-call-for-prek-teachers-goes-back-to-work-and-school.html

Taylor, K. (2014a, March 12). A Study Seeks to Determine What Makes Prekindergarten Successful. The New York Times. Retrieved from https://www.nytimes.com/2014/03/13/nyregion/a-study-seeks-to-determine-whatmakes-prekindergarten-successful.html

Taylor, K. (2014b, July 15). Group Aiding de Blasio Spent \$1.7 Million in First Half of '14. The New York Times. Retrieved from https://www.nytimes.com/2014/07/16/nyregion/group-aiding-de-blasio-spent-1-7million-in-first-half-of-14.html

Taylor, K. (2014c, August 28). In First Year of Pre-K Expansion, a Rush to Beat the School Bell. The New York Times. Retrieved from https:/www.nytimes.com/2014/08/29/nyregion/new-york-pre-k-expansion.html

Taylor, K. (2014d, August 29). Pre-K Clash May Hint at the Start of a Rivalry Between de Blasio and Stringer. The New York Times. Retrieved from 


\section{NEWS FRAMING OF UNIVERSAL PRE-K ROLLOUT IN NYC}

https://www.nytimes.com/2014/08/30/nyregion/pre-k-clash-may-hint-at-the-startof-a-rivalry-between-de-blasio-and-stringer.html

Taylor, K. (2014e, September 2). New York Cancels or Postpones Opening of 45 Pre-K Programs. The New York Times. Retrieved from https:/www.nytimes.com/2014/09/03/nyregion/new-york-cancels-or-postponesopening-of-45-pre-k-programs.html

The New York Times. (2014, April 9). De Blasio: "You Can’t Be Passive in a Role Like This." The New York Times. Retrieved from https://www.nytimes.com/2014/04/10/nyregion/de-blasio-you-cant-be-passive-in-arole-like-this.html 
NEWS FRAMING OF UNIVERSAL PRE-K ROLLOUT IN NYC

\section{Appendix E - WNYC Articles Collected for Analysis}

Bergin, B., \& Khan, Y. (2014, March 25). If You're Looking for a Pre-K Teaching Job, You're in Luck. WNYC. Retrieved from http://www.wnyc.org/story/if-yourelooking-pre-k-teaching-job-youre-luck/

Collette, M. (2014, August 29). Wanted: A Few Brave Men Willing to Teach Pre-K. WNYC. Retrieved from http://www.wnyc.org/story/wanted-few-brave-men-willingteach-pre-k/

Fertig, B. (2014a, January 8). Cuomo Gives Support For Pre-K, But No Dollar Figure. WNYC. Retrieved from http://www.wnyc.org/story/cuomo-gives-support-pre-k-nodollar-figure/

Fertig, B. (2014b, January 13). Albany Dems Differ on How Far to Push for Pre-K. WNYC. Retrieved from http://www.wnyc.org/story/albany-dems-differ-how-farpush-pre-k/

Fertig, B. (2014c, January 21). Gov. Proposes One Way to Fund Pre-K, Mayor Sticks to Another. WNYC. Retrieved from http://www.wnyc.org/story/cuomo-proposes-hisown-way-fund-pre-k/

Fertig, B. (2014d, January 31). Chancellor Requests More Money for Pre-K Seats, and Less for Charter Schools. WNYC. Retrieved from http://www.wnyc.org/story/chancellor-requests-more-money-pre-k-seats-and-lesscharter-schools/

Fertig, B. (2014e, February 11). De Blasio Prepares for "Profound Fight" Over Pre-K. WNYC. Retrieved from http://www.wnyc.org/story/de-blasio-ready-profound-fightover-pre-k/

Fertig, B. (2014f, February 16). Cuomo Digs In Against de Blasio's Pre-K Tax. WNYC. Retrieved from http://www.wnyc.org/story/tale-two-pre-k-plans-cuomo-declaresno-need-de-blasios-tax/

Fertig, B. (2014g, February 25). Mayor: Now We Have the Pre-K Seats, Still Need the Funding. WNYC. Retrieved from http://www.wnyc.org/story/mayor-says-pre-kplan-ready-launch-if-state-provides-funding/

Fertig, B. (2014h, March 18). City Sees Spike in Pre-K Applications. WNYC. Retrieved from http://www.wnyc.org/story/city-sees-spike-pre-k-applications/ 


\section{NEWS FRAMING OF UNIVERSAL PRE-K ROLLOUT IN NYC}

Fertig, B. (2014i, March 31). Pre-K Supporters Call State Budget a "Win." So Do Charter Schools. WNYC. Retrieved from http://www.wnyc.org/story/pre-k-supporters-callstate-budget-win-so-do-charter-schools/

Fertig, B. (2014j, April 2). City Launches Pre-K Expansion, Adding Four Thousand New Seats. WNYC. Retrieved from http://www.wnyc.org/story/mayor-announces-firstwave-pre-k-expansion-more-seats-schools/

Fertig, B. (2014k, April 14). A Pay Raise for Pre-K Teachers. WNYC. Retrieved from http://www.wnyc.org/story/pre-k-teachers-get-raise/

Fertig, B. (20141, September 4). NYC School Year Starts with New Mayor's Imprint. WNYC. Retrieved from http://www.wnyc.org/story/new-school-year-starts-newmayors-imprint/

Graber, M., \& Welby, J. (2014, January 5). NY Senate Leader Pushes de Blasio's Pre-K Plan. WNYC. Retrieved from http://www.wnyc.org/story/state-senator-push-deblasios-universal-pre-k-plan/

Jones, C. (2014, June 2). Map: See Which Neighborhoods Benefit the Most from Pre-K Expansion. WNYC. Retrieved from http://www.wnyc.org/story/map-pre-k-expandssome-neighborhoods-fair-better-others/

Jones, C., \& Khan, Y. (2014, June 5). Demand Outstrips Supply for NYC Pre-K Seats. WNYC. Retrieved from http://www.wnyc.org/story/families-get-offers-andrejections-public-school-pre-k/

Khan, Y. (2014a, January 6). Mayor Contends a City Tax for Pre-K Offers Stability. $W N Y C$. Retrieved from http://www.wnyc.org/story/mayor-pre-k-funds-moresustainable-tax-statefunds/?utm_source $=$ sharedUrl\&utm_medium $=$ metatag\&utm_campaign $=$ sharedUrl

Khan, Y. (2014b, January 14). Showtime: Application Season for Kindergarten Opens. WNYC. Retrieved from http://www.wnyc.org/story/its-showtime-new-kindergartenapplication/

Khan, Y. (2014c, January 27). De Blasio: The Rich Won't Mind Paying For Pre-K. WNYC. Retrieved from http://www.wnyc.org/story/ahead-albany-hearing-de-blasioreleases-pre-k-expansion-plan/

Khan, Y. (2014d, February 5). Can \$10,239 Buy Quality Pre-K? WNYC. Retrieved from http://www.wnyc.org/story/what-10239-could-buy-pre-k-quality/ 


\section{NEWS FRAMING OF UNIVERSAL PRE-K ROLLOUT IN NYC}

Khan, Y. (2014e, March 7). Behind the Scenes, Pre-K Plans Move Forward. WNYC. Retrieved from http://www.wnyc.org/story/pre-k-expansion-plans-move-forwardbehind-scenes/

Khan, Y. (2014f, March 7). The Heart-Racing Scramble That Is Applying to Pre-K. WNYC. Retrieved from http://www.wnyc.org/story/heart-racing-scramble-applyingpre-k/

Khan, Y. (2014g, March 13). Senate Leaders Propose Full Pre-K Funding for New York City, Minus the Tax Increase. WNYC. Retrieved from http://www.wnyc.org/story/senate-leaders-propose-full-funding-new-york-city-prek-minus-tax-increase/

Khan, Y. (2014h, April 22). Time's Up to Apply for Pre-K in NYC Schools. WNYC. Retrieved from http://www.wnyc.org/story/times-apply-pre-k-nyc-schools/

Khan, Y. (2014i, April 24). NYC Officials Expect a "Big Lift" in Pre-K Expansion. WNYC. Retrieved from http://www.wnyc.org/story/city-officials-outlinechallenges-rapid-pre-k-expansion/

Khan, Y. (2014j, April 24). Pre-K Applications Spike In NYC. WNYC. Retrieved from http://www.wnyc.org/story/city-reports-spike-pre-k-applications/

Khan, Y. (2014k, April 25). Charter Schools Get in on City's Pre-K Expansion. WNYC. Retrieved from http://www.wnyc.org/story/charter-operators-can-now-put-hat-ringoffer-pre-k/

Khan, Y. (20141, May 27). City Builds Its Pool of Pre-K Teachers. WNYC. Retrieved from http://www.wnyc.org/story/city-widens-its-pool-pre-k-teachers/

Khan, Y. (2014m, May 28). All Metrics on Deck For Pre-K Expansion. WNYC. Retrieved from http://www.wnyc.org/story/how-soon-will-we-know-if-pre-k-working/

Khan, Y. (2014n, May 29). Early Childhood Teachers Come to the Defense of Play. WNYC. Retrieved from http://www.wnyc.org/story/making-case-play/

Khan, Y. (2014o, May 30). NYC Unveils Next Wave of Pre-K Seats. WNYC. Retrieved from http://www.wnyc.org/story/new-pre-k-options-now-available-communityorganizations/

Khan, Y. (2014p, July 11). Six NYC Charter Schools Join Pre-K Expansion. WNYC. Retrieved from http://www.wnyc.org/story/six-nyc-charter-schools-offer-pre-k-fall/ 


\section{NEWS FRAMING OF UNIVERSAL PRE-K ROLLOUT IN NYC}

Luckey, L. (2014, March 16). Mayor de Blasio Reaches Out to Push Expanded Pre-K. WNYC. Retrieved from http://www.wnyc.org/story/mayor-de-blasio-reaches-outpush-expanded-pre-k/

Parents Give New Kindergarten Application Mixed Reviews. (2014, January 28). WNYC. Retrieved from http://www.wnyc.org/story/families-strategize-new-kindergartenapplication/

SchoolBook editors. (2014, April 18). Pre-K: You've Got Questions, She's Got Answers. WNYC. Retrieved from http://www.wnyc.org/story/pre-k-youve-got-questions-shesgot-answers/

Shulman, R. (2014a, July 11). Bank Street Helps NYC Get Pre-K Teachers Ready for Fall Expansion. WNYC. Retrieved from http://www.wnyc.org/story/bank-streethelps-get-nyc-pre-k-teachers-ready-fall-expansion/

Shulman, R. (2014b, July 22). Pre-K Program Seeking Teacher: Must Be Caring. WNYC. Retrieved from http://www.wnyc.org/story/pre-k-program-seeking-teacher-mustbe-caring/

Shulman, R. (2014c, August 4). Tiny Furniture Makers in Demand as NYC Pre-K Orders Roll In. WNYC. Retrieved from http://www.wnyc.org/story/furnishing-prekindergarten-expansion/

Shulman, R. (2014d, August 5). De Blasio Cheers on National Pre-K Movement. WNYC. Retrieved from http://www.wnyc.org/story/mayor-advocates-national-pre-k/

Shulman, R. (2014e, August 14). Basic Training for Pre-K Teachers. WNYC. Retrieved from http://www.wnyc.org/story/basic-training-pre-k-teachers/

Shulman, R. (2014f, August 19). Mayor Rallies the Pre-K Troops. WNYC. Retrieved from http://www.wnyc.org/story/mayor-gets-cheers-pre-k-crash-course/

Shulman, R. (2014g, August 19). The Journey to Pre-K Starts with Festivals and Parades. WNYC. Retrieved from http://www.wnyc.org/story/enrolling-four-year-olds-fillpre-k-seats/

Shulman, R. (2014h, August 27). Comptroller, Mayor Face Off on Pre-K Readiness. WNYC. Retrieved from http://www.wnyc.org/story/comptroller-concerned-aboutsafety-pre-k-sites/

Shulman, R. (2014i, August 28). Mayor: Pre-K Enrollment on Target, and Sites are Safe. WNYC. Retrieved from http://www.wnyc.org/story/mayor-pre-k-enrollment-targetand-sites-are-safe/ 


\section{NEWS FRAMING OF UNIVERSAL PRE-K ROLLOUT IN NYC}

Shulman, R. (2014j, September 2). Safety Issues Shutter Nine Pre-K Programs, Delay Opening for Dozens. WNYC. Retrieved from http:/www.wnyc.org/story/cityrevokes-contracts-nine-pre-k-programs-over-health-and-safety/

Shulman, R. (2014k, September 4). Expectations Run High for NYC Pre-K Expansion. $W N Y C$. Retrieved from http://www.wnyc.org/story/expectations-run-high-nyc-prek-expansion/

Shulman, R. (20141, September 4). NYC Kicks Off School Year with Smooth Rollout of Expanded Pre-K. WNYC. Retrieved from http://www.wnyc.org/story/more-51000kids-start-first-day-pre-k/

Shulman, R. (2014m, September 4). NYC Mayor Takes Victory Lap as School Opens with Expanded Pre-K. WNYC. Retrieved from http://www.wnyc.org/story/nycmayor-takes-victory-lap-school-opens-expanded-pre-k/

Shulman, R. (2014n, September 9). Seats Remain Unfilled in Pre-K Expansion Despite High Demand. WNYC. Retrieved from http://www.wnyc.org/story/seats-remainunfilled-pre-k-expansion-despite-high-demand/

Shulman, R. (2014o, October 3). Finding Her Way as a New Pre-K Teacher. WNYC. Retrieved from http://www.wnyc.org/story/finding-her-way-new-pre-k-teacher/

Shulman, R. (2014p, October 6). New York City Gives Pre-K Programs More Time to Recruit Students. WNYC. Retrieved from http://www.wnyc.org/story/new-yorkcity-gives-pre-k-programs-more-time-recruit-students/

Shulman, R. (2014q, October 7). NYC Conducting Careful Tally of Pre-K Expansion Numbers. $W N Y C$. Retrieved from http://www.wnyc.org/story/counting-four-yearolds-enrolled-pre-k/

Shulman, R. (2014r, October 30). Assessors Take the Pulse of New York's Pre-K Expansion. WNYC. Retrieved from http://www.wnyc.org/story/assessors-takepulse-pre-k-expansion/

Shulman, R. (2014s, November 4). In Sprawling Pre-K Network, NYC Rates Leave Some Centers Falling Short. WNYC. Retrieved from http://www.wnyc.org/story/diverse-and-sprawling-pre-k-network-some-programsshort-funds/

Shulman, R. (2014t, November 12). NYC Pre-K Enrollment Exceeds De Blasio's Target. WNYC. Retrieved from http://www.wnyc.org/story/pre-k-enrollment-target/ 


\section{NEWS FRAMING OF UNIVERSAL PRE-K ROLLOUT IN NYC}

Shulman, R. (2014u, November 19). City Backtracks on Report Cards for PreKindergarten Students. WNYC. Retrieved from http://www.wnyc.org/story/confusing-policy-pre-k-report-cards/

Shulman, R. (2014v, December 2). Training for Pre-K Teachers Puts Music Front and Center. $W N Y C$. Retrieved from http://www.wnyc.org/story/pre-k-teachers-learntechniques-reach-kids-through-music/

Shulman, R. (2014w, December 3). Amid Pre-K Expansion, Some Classrooms Closing. WNYC. Retrieved from http://www.wnyc.org/story/pre-k-network-expands-someclassrooms-close/

Shulman, R. (2014x, December 10). Obama Announces Funding for More Pre-K in New York, New Jersey. WNYC. Retrieved from http://www.wnyc.org/story/white-houseawards-funding-more-pre-k-new-york-state/

Shulman, R. (2014y, December 17). Making Pre-K Teachers Better through Coaching. WNYC. Retrieved from http://www.wnyc.org/story/making-better-pre-k-teachersthrough-coaching/

Shulman, R. (2014z, December 24). For Principals, Lessons in Teaching Four-Year-Olds. $W N Y C$. Retrieved from http://www.wnyc.org/story/principals-lessons-teachingfour-year-olds/ 


\section{NEWS FRAMING OF UNIVERSAL PRE-K ROLLOUT IN NYC}

\section{Appendix F - Identifiers}

\begin{tabular}{|c|c|c|c|}
\hline Identifier & Date & Author & Title \\
\hline CHALK01 & $1 / 1 / 14$ & Cramer, Philissa & $\begin{array}{l}\text { De Blasio's inaugural address features pre-K plan } \\
\text { heavily }\end{array}$ \\
\hline CHALK02 & $1 / 6 / 14$ & Decker, Geoff & $\begin{array}{l}\text { Once a skeptic, Mulgrew endorses Mayor de Blasio's } \\
\text { pre-K tax }\end{array}$ \\
\hline CHALK03 & $1 / 15 / 14$ & Decker, Geoff & De Blasio leaves the door open for charter pre-K's \\
\hline CHALK04 & $1 / 15 / 14$ & Decker, Geoff & Cuomo commission endorses charter schools for pre-K \\
\hline CHALK05 & $1 / 21 / 14$ & $\begin{array}{l}\text { Cramer, Philissa; } \\
\text { Darville, Sarah }\end{array}$ & $\begin{array}{l}\text { Heading to Bank Street, Polakow-Suransky is first to } \\
\text { exit Fariña's ed department }\end{array}$ \\
\hline CHALK06 & $1 / 22 / 14$ & Decker, Geoff & $\begin{array}{l}\text { Cuomo budget: Funds for pre-K, technology, and merit } \\
\text { pay }\end{array}$ \\
\hline CHALK07 & $1 / 27 / 14$ & Cramer, Philissa & De Blasio's state budget testimony centers on pre-K plan \\
\hline CHALK08 & $1 / 27 / 14$ & Cramer, Philissa & $\begin{array}{l}\text { De Blasio unveils implementation plan for lofty pre-K } \\
\text { proposal }\end{array}$ \\
\hline CHALK09 & $1 / 27 / 14$ & Decker, Geoff & $\begin{array}{l}\text { During hearing, de Blasio's pre-K gatekeepers scrutinize } \\
\text { his plan }\end{array}$ \\
\hline CHALK10 & $1 / 28 / 14$ & Darville, Sarah & $\begin{array}{l}\text { To implement de Blasio's pre-K plan, Dept. of Education } \\
\text { faces a formidable to-do list }\end{array}$ \\
\hline CHALK11 & $1 / 28 / 14$ & Decker, Geoff & $\begin{array}{l}\text { In first budget testimony, Fariña echoes call for de } \\
\text { Blasio's pre-K tax }\end{array}$ \\
\hline CHALK12 & $1 / 28 / 14$ & Decker, Geoff & $\begin{array}{l}\text { King says statewide pre-K would cost far more than } \\
\text { Cuomo budgeted }\end{array}$ \\
\hline CHALK13 & $1 / 31 / 14$ & Cramer, Philissa & $\begin{array}{l}\text { Pre-K in and charter schools out in de Blasio school } \\
\text { construction plan }\end{array}$ \\
\hline CHALK14 & $2 / 4 / 14$ & Darville, Sarah & $\begin{array}{l}\text { Children's Aid CEO tapped to lead city's pre-K, } \\
\text { community schools efforts }\end{array}$ \\
\hline CHALK15 & $2 / 6 / 14$ & Wall, Patrick & $\begin{array}{l}\text { In teacher pay gap, another obstacle for de Blasio's pre- } \\
\text { K plan }\end{array}$ \\
\hline CHALK16 & $2 / 10 / 14$ & Cramer, Philissa & $\begin{array}{l}\text { Legislators squabbling over whether to vote on de Blasio } \\
\text { pre-K tax plan }\end{array}$ \\
\hline CHALK17 & $2 / 10 / 14$ & Cramer, Philissa & $\begin{array}{l}\text { Lots of pre-K, but little education news, in de Blasio } \\
\text { address }\end{array}$ \\
\hline CHALK18 & $2 / 10 / 14$ & Darville, Sarah & $\begin{array}{l}\text { After } 23 \text { years, Canada stepping down as Harlem } \\
\text { Children's Zone CEO }\end{array}$ \\
\hline CHALK19 & $2 / 11 / 14$ & Darville, Sarah & $\begin{array}{l}\text { Fariña offers more support for pre-K, but no new details } \\
\text { on charters or teacher pay }\end{array}$ \\
\hline CHALK20 & $2 / 12 / 14$ & Cramer, Philissa & $\begin{array}{l}\text { Children's Aid alum to head education department's pre- } \\
\text { K efforts }\end{array}$ \\
\hline CHALK21 & $2 / 25 / 14$ & Darville, Sarah & $\begin{array}{l}\text { De Blasio: We have the space for pre-K and now we } \\
\text { need the money }\end{array}$ \\
\hline CHALK22 & $2 / 25 / 14$ & Darville, Sarah & $\begin{array}{l}\text { Fariña: Principals have already offered } 800 \text { classrooms } \\
\text { for pre-K }\end{array}$ \\
\hline CHALK23 & $3 / 4 / 14$ & Decker, Geoff & $\begin{array}{l}\text { Cuomo touts charter schools in surprise rally } \\
\text { appearance, clouding de Blasio's pre-K lobby day }\end{array}$ \\
\hline CHALK24 & $3 / 4 / 14$ & Wall, Patrick & $\begin{array}{l}\text { With funding uncertain, city pushes back pre-K } \\
\text { enrollment deadline }\end{array}$ \\
\hline CHALK25 & $3 / 7 / 14$ & Cramer, Philissa & De Blasio recruits parent bloggers in pre-K push \\
\hline
\end{tabular}




\section{NEWS FRAMING OF UNIVERSAL PRE-K ROLLOUT IN NYC}

\begin{tabular}{|c|c|c|c|}
\hline CHALK26 & $3 / 9 / 14$ & Decker, Geoff & City schools boss preaches pre-K at church congregation \\
\hline CHALK27 & $3 / 10 / 14$ & Cramer, Philissa & $\begin{array}{l}\text { City officials soften tone on pre-K funding, Success } \\
\text { standoff }\end{array}$ \\
\hline CHALK28 & $3 / 12 / 14$ & Decker, Geoff & $\begin{array}{l}\text { Assembly spending plan includes statewide pre-K funds, } \\
\text { extra } \$ 1 \text { billion for schools }\end{array}$ \\
\hline CHALK29 & $3 / 17 / 14$ & Cramer, Philissa & $\begin{array}{l}\text { What de Blasio says when he talks to parents about pre- } \\
\mathrm{K}\end{array}$ \\
\hline CHALK30 & $3 / 20 / 14$ & Neuwirth, Rebecca & $\begin{array}{l}\text { What my family got out of daycare that public pre-K } \\
\text { could provide }\end{array}$ \\
\hline CHALK31 & $3 / 21 / 14$ & Darville, Sarah & $\begin{array}{l}\text { Pre-K recruitment site to help connect teachers and } \\
\text { community organizations }\end{array}$ \\
\hline CHALK32 & $3 / 25 / 14$ & Wall, Patrick & $\begin{array}{l}\text { City plans Teaching Fellows-inspired program for pre-K } \\
\text { teachers }\end{array}$ \\
\hline CHALK33 & $3 / 29 / 14$ & Decker, Geoff & $\begin{array}{l}\text { Pre-K funds, charter school protections, and Common } \\
\text { Core changes in state budget deal }\end{array}$ \\
\hline CHALK34 & $4 / 3 / 14$ & Decker, Geoff & $\begin{array}{l}\text { At pre-K event, Silver reminds de Blasio: Don't forget } \\
\text { classroom trailers }\end{array}$ \\
\hline CHALK35 & $4 / 3 / 14$ & Decker, Geoff & $\begin{array}{l}\text { With state funding secure, Mayor de Blasio announces } \\
\text { locations of new school pre-K programs }\end{array}$ \\
\hline CHALK36 & $4 / 14 / 14$ & Wall, Patrick & $\begin{array}{l}\text { City aims to close pre-K teacher pay gap with salary } \\
\text { hikes }\end{array}$ \\
\hline CHALK37 & $4 / 24 / 14$ & Darville, Sarah & $\begin{array}{l}\text { Applications for school-based pre-K up } 36 \text { percent, city } \\
\text { says }\end{array}$ \\
\hline CHALK38 & $4 / 28 / 14$ & Decker, Geoff & $\begin{array}{l}\text { City hurrying to allow charter schools to open pre-K } \\
\text { programs, but big questions remain }\end{array}$ \\
\hline CHALK39 & $4 / 28 / 14$ & Decker, Geoff & $\begin{array}{l}\text { In Albany, officials wave pre-K warning flags for New } \\
\text { York City }\end{array}$ \\
\hline CHALK40 & $5 / 27 / 14$ & $\begin{array}{l}\text { Sokoloff-Rubin, } \\
\text { Emma }\end{array}$ & $\begin{array}{l}\text { A birds-eye view of every public school pre-K seat in } \\
\text { the city }\end{array}$ \\
\hline CHALK41 & $5 / 28 / 14$ & Decker, Geoff & $\begin{array}{l}\text { Eleven charter schools vie to help de Blasio launch pre- } \\
\text { K, with some anxiety }\end{array}$ \\
\hline CHALK42 & $5 / 30 / 14$ & Wall, Patrick & $\begin{array}{l}\text { City approves } 10,400 \text { new pre-K seats in sites across the } \\
\text { city }\end{array}$ \\
\hline CHALK43 & $6 / 4 / 14$ & $\begin{array}{l}\text { Sokoloff-Rubin, } \\
\text { Emma }\end{array}$ & $\begin{array}{l}\text { In separate special education system for pre-K, } \\
\text { principals see hurdles they expect will grow }\end{array}$ \\
\hline CHALK 44 & $6 / 4 / 14$ & Schechter, Jackie & $\begin{array}{l}\text { De Blasio defends quality of community-based pre-K } \\
\text { sites }\end{array}$ \\
\hline CHALK45 & $6 / 5 / 14$ & $\begin{array}{l}\text { McIntire, Mary } \\
\text { Ellen }\end{array}$ & $\begin{array}{l}62 \text { percent of applicants get a public-school pre-K } \\
\text { match, but many left waiting }\end{array}$ \\
\hline CHALK46 & $6 / 11 / 14$ & $\begin{array}{l}\text { Sokoloff-Rubin, } \\
\text { Emma }\end{array}$ & $\begin{array}{l}\text { Across elementary schools, an array of motives for } \\
\text { adding pre-K seats }\end{array}$ \\
\hline CHALK47 & $6 / 12 / 14$ & $\begin{array}{l}\text { Schechter, Jackie; } \\
\text { Wall, Patrick }\end{array}$ & $\begin{array}{l}\text { In pursuit of pre-K goal, city goes to great lengths to } \\
\text { enlist yeshivas }\end{array}$ \\
\hline CHALK48 & $7 / 11 / 14$ & $\begin{array}{l}\text { McIntire, Mary } \\
\text { Ellen }\end{array}$ & $\begin{array}{l}\text { Six charter schools now making final plans to launch } \\
\text { pre-K this fall }\end{array}$ \\
\hline CHALK49 & $7 / 11 / 14$ & Glazer, Jessica & $\begin{array}{l}\text { City plans Bank Street teacher training ahead of fall pre- } \\
\mathrm{K} \text { push }\end{array}$ \\
\hline CHALK50 & $7 / 24 / 14$ & Glazer, Jessica & $\begin{array}{l}\text { At a homeless shelter, a pre-K program almost like any } \\
\text { other }\end{array}$ \\
\hline CHALK51 & $8 / 1 / 14$ & Cramer, Philissa & $\begin{array}{l}\text { What We're Reading: An argument for seeing pre-K as a } \\
\text { means, not an end }\end{array}$ \\
\hline
\end{tabular}




\section{NEWS FRAMING OF UNIVERSAL PRE-K ROLLOUT IN NYC}

\begin{tabular}{|c|c|c|c|}
\hline CHALK52 & $8 / 5 / 14$ & Schechter, Jackie & $\begin{array}{l}\text { At national summit, Fariña says she will keep 'stress } \\
\text { factor' out of pre-K }\end{array}$ \\
\hline CHALK53 & $8 / 6 / 14$ & Schechter, Jackie & $\begin{array}{l}\text { Two half-day pre-K programs do not a full day make, } \\
\text { policy brief says }\end{array}$ \\
\hline CHALK54 & $8 / 12 / 14$ & $\begin{array}{l}\text { Sokoloff-Rubin, } \\
\text { Emma }\end{array}$ & $\begin{array}{l}\text { Buery defends pre-K guidelines issued to religious } \\
\text { schools }\end{array}$ \\
\hline CHALK55 & $8 / 13 / 14$ & Glazer, Jessica & $\begin{array}{l}\text { As the first day of school approaches, the city trains } \\
\text { thousands of universal pre-K teachers }\end{array}$ \\
\hline CHALK56 & $8 / 19 / 14$ & $\begin{array}{l}\text { Sokoloff-Rubin, } \\
\text { Emma }\end{array}$ & $\begin{array}{l}\text { With day one fast approaching, de Blasio and Fariña } \\
\text { rally pre-K teachers }\end{array}$ \\
\hline CHALK57 & $8 / 22 / 14$ & Glazer, Jessica & $\begin{array}{l}\text { After combined effort, city agencies say health } \\
\text { violations at pre-K sites are down }\end{array}$ \\
\hline CHALK58 & $8 / 25 / 14$ & $\begin{array}{l}\text { Cummings, } \\
\text { Madeleine }\end{array}$ & $\begin{array}{l}\text { As city seeks out new pre-K teachers, a training } \\
\text { challenge grows }\end{array}$ \\
\hline CHALK59 & $8 / 26 / 14$ & $\begin{array}{l}\text { Sokoloff-Rubin, } \\
\text { Emma }\end{array}$ & Are principals prepared to evaluate pre-K teachers? \\
\hline CHALK60 & $8 / 28 / 14$ & Decker, Geoff & $\begin{array}{l}\text { Stringer: } 70 \text { percent of pre-K contracts haven't been } \\
\text { vetted }\end{array}$ \\
\hline CHALK61 & $8 / 28 / 14$ & Glazer, Jessica & $\begin{array}{l}\text { Most pre-K seats are full one week before the start of } \\
\text { school, city says }\end{array}$ \\
\hline CHALK62 & $8 / 29 / 14$ & Decker, Geoff & $\begin{array}{l}\text { Education leaders urge patience for de Blasio's pre-K } \\
\text { plans }\end{array}$ \\
\hline CHALK63 & $9 / 2 / 14$ & Glazer, Jessica & Nine pre-K sites won't open because of safety concerns \\
\hline CHALK64 & $9 / 4 / 14$ & $\begin{array}{l}\text { Glazer, Jessica; } \\
\text { Wall, Patrick }\end{array}$ & $\begin{array}{l}\text { Thousands of four-year-olds help de Blasio fulfill pre-K } \\
\text { goal }\end{array}$ \\
\hline CHALK65 & $9 / 5 / 14$ & Cramer, Philissa & $\begin{array}{l}\text { What We're Reading: Pre-K to become a federal school } \\
\text { turnaround strategy }\end{array}$ \\
\hline CHALK66 & $9 / 23 / 14$ & Wall, Patrick & $\begin{array}{l}\text { Classes have started, but some struggling schools still } \\
\text { await clear guidance from the city }\end{array}$ \\
\hline CHALK67 & $10 / 8 / 14$ & Glazer, Jessica & $\begin{array}{l}\text { After study questions equity of pre-K expansion, city } \\
\text { pushes back }\end{array}$ \\
\hline CHALK68 & $11 / 5 / 14$ & Decker, Geoff & $\begin{array}{l}\text { Voters greenlight } \$ 780 \text { million for pre-K construction, } \\
\text { trailer removal }\end{array}$ \\
\hline CHALK69 & $11 / 13 / 14$ & Decker, Geoff & $\begin{array}{l}\text { 1,700 late enrollees push city pre-K enrollment over de } \\
\text { Blasio's goal }\end{array}$ \\
\hline CHALK70 & $12 / 2 / 14$ & Snyder, Stephanie & $\begin{array}{l}\text { What defined } 2014 \text { for Chalkbeat readers? Pre-K, a new } \\
\text { contract, and some successful students }\end{array}$ \\
\hline NYT01 & $1 / 1 / 14$ & Chozick, Amy & $\begin{array}{l}\text { With Clintons in His Corner, de Blasio Bolsters Ties to } \\
\text { His Party's â } €^{\sim} \text { Gold Standard' }\end{array}$ \\
\hline NYT02 & $1 / 1 / 14$ & $\begin{array}{l}\text { Grynbaum, } \\
\text { Michael M. }\end{array}$ & Taking Office, de Blasio Vows to Fix Inequity \\
\hline NYT03 & $1 / 3 / 14$ & Powell, Michael & De Blasio's Next Task Is Turning Passion Into Policy \\
\hline NYT04 & $1 / 6 / 14$ & $\begin{array}{l}\text { Grynbaum, } \\
\text { Michael M.; Craig, } \\
\text { Susanne }\end{array}$ & $\begin{array}{l}\text { Clash of Priorities Sets Up Cuomo-de Blasio Showdown } \\
\text { on Pre-K Push }\end{array}$ \\
\hline NYT05 & $1 / 8 / 14$ & $\begin{array}{l}\text { Craig, Susanne; } \\
\text { Mckinley, Jesse }\end{array}$ & $\begin{array}{l}\text { In Speech, Cuomo Pledges Lower Taxes and Statewide } \\
\text { Pre-K }\end{array}$ \\
\hline NYT06 & $1 / 16 / 14$ & $\begin{array}{l}\text { Hernãndez, Javier } \\
\text { C. }\end{array}$ & $\begin{array}{l}\text { De Blasio, a Critic of Charter Schools, May Need Them } \\
\text { for His Pre-K Agenda }\end{array}$ \\
\hline NYT07 & $1 / 20 / 14$ & Kaplan, Thomas & $\begin{array}{l}\text { Cuomo's Budget Is Said to Include Ethics and Campaign } \\
\text { Finance Reforms }\end{array}$ \\
\hline
\end{tabular}




\section{NEWS FRAMING OF UNIVERSAL PRE-K ROLLOUT IN NYC}

\begin{tabular}{|c|c|c|c|}
\hline NYT08 & $1 / 21 / 14$ & $\begin{array}{l}\text { Grynbaum, } \\
\text { Michael M.; } \\
\text { Kaplan, Thomas }\end{array}$ & $\begin{array}{l}\text { Pre-K Plan Puts Cuomo at Odds With de Blasio on } \\
\text { Funding }\end{array}$ \\
\hline NYT09 & $1 / 23 / 14$ & Kaplan, Thomas & $\begin{array}{l}\text { Cuomo Sweetens Pre-K Deal: â } €^{\sim} \text { Whatever' Mayor } \\
\text { Needs }\end{array}$ \\
\hline NYT10 & $1 / 23 / 14$ & Stewart, Nikita & $\begin{array}{l}\text { De Blasio Urges Mayors to Forge an â€`Urban } \\
\text { Consensus' }\end{array}$ \\
\hline NYT11 & $1 / 23 / 14$ & Powell, Michael & Governor Says It's All Settled but the Money \\
\hline NYT12 & $1 / 26 / 14$ & $\begin{array}{l}\text { Hernãndez, Javier } \\
\text { C. }\end{array}$ & Lessons for de Blasio in New Jersey's Free Pre-K \\
\hline NYT13 & $1 / 27 / 14$ & $\begin{array}{l}\text { Kaplan, Thomas; } \\
\text { Hernãndez, Javier } \\
\text { C. }\end{array}$ & De Blasio, on Cuomo's Turf, Stands By Pre-K Strategy \\
\hline NYT14 & $1 / 28 / 14$ & $\begin{array}{l}\text { Hernãndez, Javier } \\
\text { C. }\end{array}$ & $\begin{array}{l}\text { Estimate for Statewide Pre-K in New York Puts Schools } \\
\text { Chief in a Tangle }\end{array}$ \\
\hline NYT15 & $1 / 31 / 14$ & $\begin{array}{l}\text { Hernãndez, Javier } \\
\text { C. }\end{array}$ & Funds Meant for Charters May Be Diverted to Pre-K \\
\hline NYT16 & $2 / 7 / 14$ & $\begin{array}{l}\text { Hernãndez, Javier } \\
\text { C.; Stewart, Nikita }\end{array}$ & De Blasio Tests Political Might in Pre-K Push \\
\hline NYT17 & $2 / 10 / 14$ & $\begin{array}{l}\text { Hernãndez, Javier } \\
\text { C. }\end{array}$ & Chief of Harlem Children's Program Will Step Aside \\
\hline NYT18 & $2 / 12 / 14$ & Kaplan, Thomas & $\begin{array}{l}\text { Survey Suggests Voters Prefer Cuomo's Proposal for } \\
\text { Pre-K }\end{array}$ \\
\hline NYT19 & $2 / 12 / 14$ & Powell, Michael & For de Blasio, No Magic Lost in Budget Draft \\
\hline NYT20 & $2 / 13 / 14$ & Dwyer, Jim & $\begin{array}{l}\text { In Debate Over Paying for Pre-K, Little Agreement } \\
\text { Aside From the Goal }\end{array}$ \\
\hline NYT21 & $2 / 16 / 14$ & Craig, Susanne & De Blasio Strikes Conciliatory Note on Pre-K \\
\hline NYT22 & $2 / 25 / 14$ & Baker, $\mathrm{Al}$ & De Blasio Says New York Can Add 29,000 Pre-K Seats \\
\hline NYT23 & $2 / 27 / 14$ & Bellafante, Ginia & A Community Center as DMZ in City's Class War \\
\hline NYT24 & $3 / 4 / 14$ & $\begin{array}{l}\text { Baker, Al; } \\
\text { Hernãndez, Javier } \\
\text { C. }\end{array}$ & $\begin{array}{l}\text { De Blasio and Operator of Charter School Empire Do } \\
\text { Battle }\end{array}$ \\
\hline NYT25 & $3 / 4 / 14$ & Santora, Marc & $\begin{array}{l}\text { Cuomo Vows to Defend Charter Schools, Setting Up } \\
\text { Another Battle With de Blasio }\end{array}$ \\
\hline NYT26 & $3 / 6 / 14$ & $\begin{array}{l}\text { Craig, Thomas } \\
\text { Kaplan, Susanne; } \\
\text { Grynbaum, } \\
\text { Michael M. }\end{array}$ & $\begin{array}{l}\text { Cuomo Burnishes His Political Brand, Using de Blasio } \\
\text { as His Foil }\end{array}$ \\
\hline NYT27 & $3 / 6 / 14$ & $\begin{array}{l}\text { Hernãndez, Javier } \\
\text { C. }\end{array}$ & $\begin{array}{l}\text { De Blasio and Dolan Announce a Push for More Pre-K } \\
\text { Classes }\end{array}$ \\
\hline NYT28 & $3 / 7 / 14$ & Baker, $\mathrm{Al}$ & $\begin{array}{l}\text { Pre-K Special Education Contractor Pleads Guilty to } \\
\text { Fraud Charge }\end{array}$ \\
\hline NYT29 & $3 / 9 / 14$ & Swarns, Rachel L. & $\begin{array}{l}\text { Among de Blasio's Priorities, Minimum Wage Waits } \\
\text { Behind Pre-K }\end{array}$ \\
\hline NYT30 & $3 / 12 / 14$ & Taylor, Kate & $\begin{array}{l}\text { A Study Seeks to Determine What Makes } \\
\text { Prekindergarten Successful }\end{array}$ \\
\hline NYT31 & $3 / 13 / 14$ & Dwyer, Jim & No Easy Task in Bid to Find Seats for Pre-K \\
\hline NYT32 & $3 / 13 / 14$ & $\begin{array}{l}\text { Kaplan, Thomas; } \\
\text { Baker, Al }\end{array}$ & $\begin{array}{l}\text { De Blasio Closes In on Pre-K Funding, but Not From a } \\
\text { Higher Tax }\end{array}$ \\
\hline
\end{tabular}




\section{NEWS FRAMING OF UNIVERSAL PRE-K ROLLOUT IN NYC}

\begin{tabular}{|c|c|c|c|}
\hline NYT33 & $3 / 14 / 14$ & $\begin{array}{l}\text { Hernãndez, Javier } \\
\text { C.; Kaplan, } \\
\text { Thomas }\end{array}$ & $\begin{array}{l}\text { Mayor's Pre-K Tax Drive: Views Vary on Its Success as } \\
\text { Widely as on Its Merits }\end{array}$ \\
\hline NYT34 & $3 / 19 / 14$ & Stewart, Nikita & Familiar Consultants Hired by de Blasio's Pre-K Drive \\
\hline NYT35 & $3 / 29 / 14$ & $\begin{array}{l}\text { Kaplan, Thomas; } \\
\text { Hernãndez, Javier } \\
\text { C. }\end{array}$ & $\begin{array}{l}\text { State Budget Deal Reached; } \$ 300 \text { Million for New York } \\
\text { City Pre-K }\end{array}$ \\
\hline NYT36 & $3 / 30 / 14$ & $\begin{array}{l}\text { Grynbaum, } \\
\text { Michael M.; } \\
\text { Kaplan, Thomas }\end{array}$ & De Blasio Betting on Pre-K to Succeed \\
\hline NYT37 & $4 / 2 / 14$ & Powell, Michael & A Victory, and a Knife in the Side \\
\hline NYT38 & $4 / 8 / 14$ & $\begin{array}{l}\text { Grynbaum, } \\
\text { Michael M. }\end{array}$ & $\begin{array}{l}\text { Pre-K Victory Ad With Mayor de Blasio's Family Aims } \\
\text { to Help Him Regain His Footing }\end{array}$ \\
\hline NYT39 & $4 / 9 / 14$ & $\begin{array}{l}\text { The New York } \\
\text { Times }\end{array}$ & De Blasio: 'You Can't Be Passive in a Role Like This' \\
\hline NYT40 & $4 / 24 / 14$ & $\begin{array}{l}\text { Hernãndez, Javier } \\
\text { C. }\end{array}$ & $\begin{array}{l}\text { Pre-K Applicants Up 36\% This Year; Mayor's Challenge } \\
\text { Is Finding Seats }\end{array}$ \\
\hline NYT41 & $5 / 9 / 14$ & Stewart, Nikita & The Women of New York's City Hall \\
\hline NYT42 & $5 / 28 / 14$ & Powell, Michael & At a Jewish Gala, de Blasio Skips His Cue to Speak Out \\
\hline NYT43 & $6 / 5 / 14$ & Baker, Al & $\begin{array}{l}\text { Less Than Half of New York City's Applicants for Pre- } \\
\text { K Get Their Top-Choice School }\end{array}$ \\
\hline NYT44 & $6 / 29 / 14$ & Ishayik, Edna & $\begin{array}{l}\text { Amid de Blasio's Pre-K Push, a Bid to Boost Learning at } \\
\text { a Weak Point in the Pipeline }\end{array}$ \\
\hline NYT45 & $7 / 8 / 14$ & Spencer, Kyle & $\begin{array}{l}\text { As New York City Expands Pre-K, Private Programs } \\
\text { Fear Teacher Drain }\end{array}$ \\
\hline NYT46 & $7 / 15 / 14$ & Taylor, Kate & $\begin{array}{l}\text { Group Aiding de Blasio Spent } \$ 1.7 \text { Million in First Half } \\
\text { of '14 }\end{array}$ \\
\hline NYT47 & $7 / 20 / 14$ & Swarns, Rachel L. & $\begin{array}{l}\text { A Parent Answering a Call for Pre-K Teachers Goes } \\
\text { Back to Work (and School) }\end{array}$ \\
\hline NYT48 & $7 / 23 / 14$ & $\begin{array}{l}\text { Hernãndez, Javier } \\
\text { C. }\end{array}$ & $\begin{array}{l}\text { At Manhattan Preschool, Accounts of Sex Abuse Case } \\
\text { Differ }\end{array}$ \\
\hline NYT49 & $8 / 4 / 14$ & Kaplan, Thomas & $\begin{array}{l}\text { Cuomo Aides Use Allies to Shore Up the Governor's } \\
\text { Image }\end{array}$ \\
\hline NYT50 & $8 / 4 / 14$ & Otterman, Sharon & $\begin{array}{l}\text { De Blasio's Prekindergarten Expansion Collides With } \\
\text { Church-State Divide }\end{array}$ \\
\hline NYT51 & $8 / 11 / 14$ & Stewart, Nikita & Task Force of Mayors Addresses Income Gap \\
\hline NYT52 & $8 / 14 / 14$ & $\begin{array}{l}\text { Schlossberg, } \\
\text { Tatiana }\end{array}$ & $\begin{array}{l}\text { One Child Recalls Being Touched by Intern at } \\
\text { Manhattan Preschool, Prosecutors Say }\end{array}$ \\
\hline NYT53 & $8 / 26 / 14$ & $\begin{array}{l}\text { Harris, Elizabeth } \\
\text { A. }\end{array}$ & Parents Scramble for Pre-K Seats in Brooklyn District \\
\hline NYT54 & $8 / 27 / 14$ & Stewart, Nikita & $\begin{array}{l}\text { New York Comptroller Is Concerned Over Pre-K } \\
\text { Contract Delays }\end{array}$ \\
\hline NYT55 & $8 / 28 / 14$ & Taylor, Kate & $\begin{array}{l}\text { In First Year of Pre-K Expansion, a Rush to Beat the } \\
\text { School Bell }\end{array}$ \\
\hline NYT56 & $8 / 29 / 14$ & Taylor, Kate & $\begin{array}{l}\text { Pre-K Clash May Hint at the Start of a Rivalry Between } \\
\text { de Blasio and Stringer }\end{array}$ \\
\hline NYT57 & $9 / 2 / 14$ & Taylor, Kate & $\begin{array}{l}\text { New York Cancels or Postpones Opening of } 45 \text { Pre-K } \\
\text { Programs }\end{array}$ \\
\hline NYT58 & $9 / 3 / 14$ & $\begin{array}{l}\text { Harris, Elizabeth } \\
\text { A. }\end{array}$ & $\begin{array}{l}\text { Final Touches Range From Flowery to Frantic as } \\
\text { Expanded Pre-K Awaits Start }\end{array}$ \\
\hline
\end{tabular}




\section{NEWS FRAMING OF UNIVERSAL PRE-K ROLLOUT IN NYC}

\begin{tabular}{|c|c|c|c|}
\hline NYT59 & $9 / 4 / 14$ & Bellafante, Ginia & $\begin{array}{l}\text { As Prekindergarten Expands in New York City, Guiding } \\
\text { Guided Play }\end{array}$ \\
\hline NYT60 & $9 / 4 / 14$ & $\begin{array}{l}\text { Harris, Elizabeth } \\
\text { A.; Taylor, Kate }\end{array}$ & 51,000 Answer de Blasio's Bell for New Pre-K \\
\hline NYT61 & $9 / 4 / 14$ & & Preschool Director Is Sentenced to Two Years in Prison \\
\hline NYT62 & $9 / 18 / 14$ & $\begin{array}{l}\text { Schlossberg, } \\
\text { Tatiana }\end{array}$ & $\begin{array}{l}\text { Restrictions Are Eased for Ex-Preschool Intern Accused } \\
\text { of Sex Abuse }\end{array}$ \\
\hline NYT63 & $10 / 2 / 14$ & Flegenheimer, Matt & $\begin{array}{l}\text { Questions Raised by Pre-K Video Sent to de Blasio } \\
\text { Campaign Supporters }\end{array}$ \\
\hline NYT64 & $11 / 6 / 14$ & $\begin{array}{l}\text { Harris, Elizabeth } \\
\text { A. }\end{array}$ & $\begin{array}{l}\text { Manhattan Preschool Teacher Who Alleged Abuse Sues } \\
\text { Over Firing }\end{array}$ \\
\hline NYT65 & $11 / 13 / 14$ & $\begin{array}{l}\text { Mckinley Jr, James } \\
\text { C. Mckinley }\end{array}$ & Sexual Abuse Case Dropped Against Intern at Preschool \\
\hline WNYC01 & $1 / 5 / 14$ & $\begin{array}{l}\text { Graber, Marc; } \\
\text { Welby, Julianne }\end{array}$ & NY Senate Leader Pushes de Blasio's Pre-K Plan \\
\hline WNYC02 & $1 / 6 / 14$ & Khan, Yasmeen & Mayor Contends a City Tax for Pre-K Offers Stability \\
\hline WNYC03 & $1 / 8 / 14$ & Fertig, Beth & Cuomo Gives Support For Pre-K, But No Dollar Figure \\
\hline WNYC04 & $1 / 13 / 14$ & Fertig, Beth & Albany Dems Differ on How Far to Push for Pre-K \\
\hline WNYC05 & $1 / 14 / 14$ & Khan, Yasmeen & Showtime: Application Season for Kindergarten Opens \\
\hline WNYC06 & $1 / 21 / 14$ & Fertig, Beth & $\begin{array}{l}\text { Gov. Proposes One Way to Fund Pre-K, Mayor Sticks to } \\
\text { Another }\end{array}$ \\
\hline WNYC07 & $1 / 27 / 14$ & Khan, Yasmeen & De Blasio: The Rich Won't Mind Paying For Pre-K \\
\hline WNYC08 & $1 / 28 / 14$ & & $\begin{array}{l}\text { Parents Give New Kindergarten Application Mixed } \\
\text { Reviews }\end{array}$ \\
\hline WNYC09 & $1 / 31 / 14$ & Fertig, Beth & $\begin{array}{l}\text { Chancellor Requests More Money for Pre-K Seats, and } \\
\text { Less for Charter Schools }\end{array}$ \\
\hline WNYC10 & $2 / 5 / 14$ & Khan, Yasmeen & Can $\$ 10,239$ Buy Quality Pre-K? \\
\hline WNYC11 & $2 / 11 / 14$ & Fertig, Beth & De Blasio Prepares for 'Profound Fight' Over Pre-K \\
\hline WNYC12 & $2 / 16 / 14$ & Fertig, Beth & Cuomo Digs In Against de Blasio's Pre-K Tax \\
\hline WNYC13 & $2 / 25 / 14$ & Fertig, Beth & $\begin{array}{l}\text { Mayor: Now We Have the Pre-K Seats, Still Need the } \\
\text { Funding }\end{array}$ \\
\hline WNYC14 & $3 / 7 / 14$ & Khan, Yasmeen & Behind the Scenes, Pre-K Plans Move Forward \\
\hline WNYC15 & $3 / 7 / 14$ & Khan, Yasmeen & The Heart-Racing Scramble That Is Applying to Pre-K \\
\hline WNYC16 & $3 / 13 / 14$ & Khan, Yasmeen & $\begin{array}{l}\text { Senate Leaders Propose Full Pre-K Funding for New } \\
\text { York City, Minus the Tax Increase }\end{array}$ \\
\hline WNYC17 & $3 / 16 / 14$ & Luckey, Lance & Mayor de Blasio Reaches Out to Push Expanded Pre-K \\
\hline WNYC18 & $3 / 18 / 14$ & Fertig, Beth & City Sees Spike in Pre-K Applications \\
\hline WNYC19 & $3 / 25 / 14$ & $\begin{array}{l}\text { Bergin, Brigid; } \\
\text { Khan, Yasmeen }\end{array}$ & $\begin{array}{l}\text { If You're Looking for a Pre-K Teaching Job, You're in } \\
\text { Luck }\end{array}$ \\
\hline WNYC20 & $3 / 31 / 14$ & Fertig, Beth & $\begin{array}{l}\text { Pre-K Supporters Call State Budget a 'Win.' So Do } \\
\text { Charter Schools. }\end{array}$ \\
\hline WNYC21 & $4 / 2 / 14$ & Fertig, Beth & $\begin{array}{l}\text { City Launches Pre-K Expansion, Adding Four Thousand } \\
\text { New Seats }\end{array}$ \\
\hline WNYC22 & $4 / 14 / 14$ & Fertig, Beth & A Pay Raise for Pre-K Teachers \\
\hline WNYC23 & $4 / 18 / 14$ & SchoolBook editors & Pre-K: You've Got Questions, She's Got Answers \\
\hline WNYC24 & $4 / 22 / 14$ & Khan, Yasmeen & Time's Up to Apply for Pre-K in NYC Schools \\
\hline WNYC25 & $4 / 24 / 14$ & Khan, Yasmeen & NYC Officials Expect a 'Big Lift' in Pre-K Expansion \\
\hline
\end{tabular}




\section{NEWS FRAMING OF UNIVERSAL PRE-K ROLLOUT IN NYC}

\begin{tabular}{|c|c|c|c|}
\hline WNYC26 & $4 / 24 / 14$ & Khan, Yasmeen & Pre-K Applications Spike In NYC \\
\hline WNYC27 & $4 / 25 / 14$ & Khan, Yasmeen & Charter Schools Get in on City's Pre-K Expansion \\
\hline WNYC28 & $5 / 27 / 14$ & Khan, Yasmeen & City Builds Its Pool of Pre-K Teachers \\
\hline WNYC29 & $5 / 28 / 14$ & Khan, Yasmeen & All Metrics on Deck For Pre-K Expansion \\
\hline WNYC30 & $5 / 29 / 14$ & Khan, Yasmeen & Early Childhood Teachers Come to the Defense of Play \\
\hline WNYC31 & $5 / 30 / 14$ & Khan, Yasmeen & NYC Unveils Next Wave of Pre-K Seats \\
\hline WNYC32 & $6 / 2 / 14$ & Jones, Coulter & $\begin{array}{l}\text { Map: See Which Neighborhoods Benefit the Most from } \\
\text { Pre-K Expansion }\end{array}$ \\
\hline WNYC33 & $6 / 5 / 14$ & $\begin{array}{l}\text { Jones, Coulter; } \\
\text { Khan, Yasmeen }\end{array}$ & Demand Outstrips Supply for NYC Pre-K Seats \\
\hline WNYC34 & $7 / 11 / 14$ & Khan, Yasmeen & Six NYC Charter Schools Join Pre-K Expansion \\
\hline WNYC35 & $7 / 11 / 14$ & Shulman, Robin & $\begin{array}{l}\text { Bank Street Helps NYC Get Pre-K Teachers Ready for } \\
\text { Fall Expansion }\end{array}$ \\
\hline WNYC36 & $7 / 22 / 14$ & Shulman, Robin & Pre-K Program Seeking Teacher: Must Be Caring \\
\hline WNYC37 & $8 / 4 / 14$ & Shulman, Robin & $\begin{array}{l}\text { Tiny Furniture Makers in Demand as NYC Pre-K Orders } \\
\text { Roll In }\end{array}$ \\
\hline WNYC38 & $8 / 5 / 14$ & Shulman, Robin & De Blasio Cheers on National Pre-K Movement \\
\hline WNYC39 & $8 / 14 / 14$ & Shulman, Robin & Basic Training for Pre-K Teachers \\
\hline WNYC40 & $8 / 19 / 14$ & Shulman, Robin & Mayor Rallies the Pre-K Troops \\
\hline WNYC41 & $8 / 19 / 14$ & Shulman, Robin & The Journey to Pre-K Starts with Festivals and Parades \\
\hline WNYC42 & $8 / 27 / 14$ & Shulman, Robin & Comptroller, Mayor Face Off on Pre-K Readiness \\
\hline WNYC43 & $8 / 28 / 14$ & Shulman, Robin & Mayor: Pre-K Enrollment on Target, and Sites are Safe \\
\hline WNYC44 & $8 / 29 / 14$ & Collette, Matt & Wanted: A Few Brave Men Willing to Teach Pre-K \\
\hline WNYC45 & $9 / 2 / 14$ & Shulman, Robin & $\begin{array}{l}\text { Safety Issues Shutter Nine Pre-K Programs, Delay } \\
\text { Opening for Dozens }\end{array}$ \\
\hline WNYC46 & $9 / 4 / 14$ & Fertig, Beth & NYC School Year Starts with New Mayor's Imprint \\
\hline WNYC47 & $9 / 4 / 14$ & Shulman, Robin & Expectations Run High for NYC Pre-K Expansion \\
\hline WNYC48 & $9 / 4 / 14$ & Shulman, Robin & $\begin{array}{l}\text { NYC Kicks Off School Year with Smooth Rollout of } \\
\text { Expanded Pre-K }\end{array}$ \\
\hline WNYC49 & $9 / 4 / 14$ & Shulman, Robin & $\begin{array}{l}\text { NYC Mayor Takes Victory Lap as School Opens with } \\
\text { Expanded Pre-K }\end{array}$ \\
\hline WNYC50 & $9 / 9 / 14$ & Shulman, Robin & $\begin{array}{l}\text { Seats Remain Unfilled in Pre-K Expansion Despite High } \\
\text { Demand }\end{array}$ \\
\hline WNYC51 & $10 / 3 / 14$ & Shulman, Robin & Finding Her Way as a New Pre-K Teacher \\
\hline WNYC52 & $10 / 6 / 14$ & Shulman, Robin & $\begin{array}{l}\text { New York City Gives Pre-K Programs More Time to } \\
\text { Recruit Students }\end{array}$ \\
\hline WNYC53 & $10 / 7 / 14$ & Shulman, Robin & $\begin{array}{l}\text { NYC Conducting Careful Tally of Pre-K Expansion } \\
\text { Numbers }\end{array}$ \\
\hline WNYC54 & $10 / 30 / 14$ & Shulman, Robin & $\begin{array}{l}\text { Assessors Take the Pulse of New York's Pre-K } \\
\text { Expansion }\end{array}$ \\
\hline WNYC55 & $11 / 4 / 14$ & Shulman, Robin & $\begin{array}{l}\text { In Sprawling Pre-K Network, NYC Rates Leave Some } \\
\text { Centers Falling Short }\end{array}$ \\
\hline WNYC56 & $11 / 12 / 14$ & Shulman, Robin & NYC Pre-K Enrollment Exceeds De Blasio's Target \\
\hline WNYC57 & $11 / 19 / 14$ & Shulman, Robin & $\begin{array}{l}\text { City Backtracks on Report Cards for Pre-Kindergarten } \\
\text { Students }\end{array}$ \\
\hline
\end{tabular}


NEWS FRAMING OF UNIVERSAL PRE-K ROLLOUT IN NYC

\begin{tabular}{|l|r|l|l|}
\hline WNYC58 & $12 / 2 / 14$ & Shulman, Robin & $\begin{array}{l}\text { Training for Pre-K Teachers Puts Music Front and } \\
\text { Center }\end{array}$ \\
\hline WNYC59 & $12 / 3 / 14$ & Shulman, Robin & Amid Pre-K Expansion, Some Classrooms Closing \\
\hline WNYC60 & $12 / 10 / 14$ & Shulman, Robin & $\begin{array}{l}\text { Obama Announces Funding for More Pre-K in New } \\
\text { York, New Jersey }\end{array}$ \\
\hline WNYC61 & $12 / 17 / 14$ & Shulman, Robin & Making Pre-K Teachers Better through Coaching \\
\hline WNYC62 & $12 / 24 / 14$ & Shulman, Robin & For Principals, Lessons in Teaching Four-Year-Olds \\
\hline
\end{tabular}


NEWS FRAMING OF UNIVERSAL PRE-K ROLLOUT IN NYC

\section{Appendix G - Source Database}

\begin{tabular}{|c|c|c|c|c|c|}
\hline Identifier & Last name & First name & Title & Affiliation & Category \\
\hline CHALK01A & de Blasio & Bill & mayor & NYC Mayor's Office & NYC official \\
\hline CHALK02A & Mulgrew & Michael & president & $\begin{array}{l}\text { United Federation of } \\
\text { Teachers }\end{array}$ & teachers union \\
\hline CHALK02B & de Blasio & Bill & mayor & NYC Mayor's Office & NYC official \\
\hline CHALK03A & Cuomo & Andrew & governor & State of New York & state official \\
\hline CHALK03B & Mead & Sara & $\begin{array}{l}\text { commission } \\
\text { member }\end{array}$ & $\begin{array}{l}\text { New York State } \\
\text { Education Reform } \\
\text { Commission }\end{array}$ & $\begin{array}{l}\text { other education } \\
\text { official }\end{array}$ \\
\hline CHALK03C & Merriman & James & $\mathrm{CEO}$ & $\begin{array}{l}\text { New York City Charter } \\
\text { School Center }\end{array}$ & $\begin{array}{l}\text { advocacy } \\
\text { organization }\end{array}$ \\
\hline CHALK03D & Mulgrew & Michael & president & $\begin{array}{l}\text { United Federation of } \\
\text { Teachers }\end{array}$ & teachers union \\
\hline CHALK04A & de Blasio & Bill & mayor & NYC Mayor's Office & NYC official \\
\hline CHALK04B & Merriman & James & $\mathrm{CEO}$ & $\begin{array}{l}\text { New York City Charter } \\
\text { School Center }\end{array}$ & $\begin{array}{l}\text { advocacy } \\
\text { organization }\end{array}$ \\
\hline CHALK05A & Nadelstern & Eric & $\begin{array}{l}\text { former deputy } \\
\text { schools } \\
\text { chancellor }\end{array}$ & $\begin{array}{l}\text { NYC Department of } \\
\text { Education }\end{array}$ & $\begin{array}{l}\text { NYC } \\
\text { education } \\
\text { official }\end{array}$ \\
\hline CHALK05B & $\begin{array}{l}\text { Polakow- } \\
\text { Suransky }\end{array}$ & Shael & deputy & $\begin{array}{l}\text { NYC Department of } \\
\text { Education }\end{array}$ & $\begin{array}{l}\text { NYC } \\
\text { education } \\
\text { official }\end{array}$ \\
\hline CHALK05C & Fariña & Carmen & $\begin{array}{l}\text { schools } \\
\text { chancellor }\end{array}$ & $\begin{array}{l}\text { NYC Department of } \\
\text { Education }\end{array}$ & $\begin{array}{l}\text { NYC } \\
\text { education } \\
\text { official }\end{array}$ \\
\hline CHALK05D & Street & John & $\begin{array}{l}\text { vice president } \\
\text { for external } \\
\text { relations }\end{array}$ & Bank Street & $\begin{array}{l}\text { college } \\
\text { administrator }\end{array}$ \\
\hline CHALK06A & Cuomo & Andrew & governor & State of New York & state official \\
\hline CHALK07A & de Blasio & Bill & mayor & NYC Mayor's Office & NYC official \\
\hline CHALK08A & Fariña & Carmen & $\begin{array}{l}\text { schools } \\
\text { chancellor }\end{array}$ & $\begin{array}{l}\text { NYC Department of } \\
\text { Education }\end{array}$ & $\begin{array}{l}\text { NYC } \\
\text { education } \\
\text { official }\end{array}$ \\
\hline CHALK08B & de Blasio & Bill & mayor & NYC Mayor's Office & NYC official \\
\hline CHALK08C & Wallack & Josh & vice president & Children's Aid Society & $\begin{array}{l}\text { advocacy } \\
\text { organization }\end{array}$ \\
\hline CHALK09A & Cusik & Michael & assemblyman & $\begin{array}{l}\text { New York State } \\
\text { Assembly }\end{array}$ & state official \\
\hline CHALK09B & de Blasio & Bill & mayor & NYC Mayor's Office & NYC official \\
\hline CHALK09C & Savino & Diana & senator & New York State Senate & state official \\
\hline CHALK09D & Magnarelli & William & assemblyman & $\begin{array}{l}\text { New York State } \\
\text { Assembly }\end{array}$ & state official \\
\hline CHALK09E & Diaz Jr. & Ruben & senator & New York State Senate & state official \\
\hline CHALK09F & Perkins & Bill & senator & New York State Senate & state official \\
\hline CHALK10A & de Blasio & Bill & mayor & NYC Mayor's Office & NYC official \\
\hline CHALK10B & & & $\begin{array}{l}\text { unnamed } \\
\text { spokesman }\end{array}$ & $\begin{array}{l}\text { NYC Department of } \\
\text { Education }\end{array}$ & $\begin{array}{l}\text { NYC } \\
\text { education } \\
\text { official }\end{array}$ \\
\hline
\end{tabular}


NEWS FRAMING OF UNIVERSAL PRE-K ROLLOUT IN NYC

\begin{tabular}{|c|c|c|c|c|c|}
\hline CHALK11A & Fariña & Carmen & $\begin{array}{l}\text { schools } \\
\text { chancellor }\end{array}$ & $\begin{array}{l}\text { NYC Department of } \\
\text { Education }\end{array}$ & $\begin{array}{l}\text { NYC } \\
\text { education } \\
\text { official }\end{array}$ \\
\hline CHALK12A & King & John & $\begin{array}{l}\text { state schools } \\
\text { chief }\end{array}$ & $\begin{array}{l}\text { New York State } \\
\text { Department of } \\
\text { Education }\end{array}$ & $\begin{array}{l}\text { other education } \\
\text { official }\end{array}$ \\
\hline CHALK12B & Brennan & James & assemblyman & $\begin{array}{l}\text { New York State } \\
\text { Assembly }\end{array}$ & state official \\
\hline CHALK12C & Breslin & Kate & $\begin{array}{l}\text { president \& } \\
\text { CEO }\end{array}$ & $\begin{array}{l}\text { Schuyler Center for } \\
\text { Analysis \& Advocacy }\end{array}$ & $\begin{array}{l}\text { advocacy } \\
\text { organization }\end{array}$ \\
\hline CHALK13A & Fariña & Carmen & $\begin{array}{l}\text { schools } \\
\text { chancellor }\end{array}$ & $\begin{array}{l}\text { NYC Department of } \\
\text { Education }\end{array}$ & $\begin{array}{l}\text { NYC } \\
\text { education } \\
\text { official }\end{array}$ \\
\hline CHALK13B & Merriman & James & $\mathrm{CEO}$ & $\begin{array}{l}\text { New York City Charter } \\
\text { School Center }\end{array}$ & $\begin{array}{l}\text { advocacy } \\
\text { organization }\end{array}$ \\
\hline CHALK14A & Buery & Richard & deputy mayor & NYC Mayor's Office & NYC official \\
\hline CHALK14B & de Blasio & Bill & mayor & NYC Mayor's Office & NYC official \\
\hline CHALK15A & De Castro & Thomas & teacher & & $\begin{array}{l}\text { classroom } \\
\text { teacher }\end{array}$ \\
\hline CHALK15B & Nocenti & David & $\begin{array}{l}\text { executive } \\
\text { director }\end{array}$ & $\begin{array}{l}\text { Union Settlement } \\
\text { Association }\end{array}$ & $\begin{array}{l}\text { principal/admi } \\
\text { nistrator }\end{array}$ \\
\hline CHALK15C & George & Raglan & $\begin{array}{l}\text { executive } \\
\text { director }\end{array}$ & DC 1707 & teachers union \\
\hline CHALK15D & Paige & Michelle & $\begin{array}{l}\text { director of } \\
\text { early } \\
\text { childhood } \\
\text { education }\end{array}$ & $\begin{array}{l}\text { Union Settlement } \\
\text { Association }\end{array}$ & $\begin{array}{l}\text { principal/admi } \\
\text { nistrator }\end{array}$ \\
\hline CHALK15E & Flores & Linda & $\begin{array}{l}\text { director of } \\
\text { early } \\
\text { childhood } \\
\text { education }\end{array}$ & Henry Street Settlement & $\begin{array}{l}\text { principal/admi } \\
\text { nistrator }\end{array}$ \\
\hline CHALK15F & Barnett & Steve & director & $\begin{array}{l}\text { National Institute for } \\
\text { Early Education } \\
\text { Research }\end{array}$ & $\begin{array}{l}\text { academic/instit } \\
\text { utionally- } \\
\text { affiliated } \\
\text { researcher }\end{array}$ \\
\hline CHALK16A & Skelos & Dean & senator & New York State Senate & state official \\
\hline CHALK16B & de Blasio & Bill & mayor & NYC Mayor's Office & NYC official \\
\hline CHALK17A & de Blasio & Bill & mayor & NYC Mayor's Office & NYC official \\
\hline CHALK18A & Canada & Geoffrey & CEO & Harlem Children's Zone & $\begin{array}{l}\text { advocacy } \\
\text { organization }\end{array}$ \\
\hline CHALK18B & $\begin{array}{l}\text { Williams- } \\
\text { Isom }\end{array}$ & Anne & $\begin{array}{l}\text { chief operating } \\
\text { officer }\end{array}$ & Harlem Children's Zone & $\begin{array}{l}\text { advocacy } \\
\text { organization }\end{array}$ \\
\hline CHALK19A & Fariña & Carmen & $\begin{array}{l}\text { schools } \\
\text { chancellor }\end{array}$ & $\begin{array}{l}\text { NYC Department of } \\
\text { Education }\end{array}$ & $\begin{array}{l}\text { NYC } \\
\text { education } \\
\text { official }\end{array}$ \\
\hline CHALK19B & Merriman & James & $\mathrm{CEO}$ & $\begin{array}{l}\text { New York City Charter } \\
\text { School Center }\end{array}$ & $\begin{array}{l}\text { advocacy } \\
\text { organization }\end{array}$ \\
\hline CHALK19C & Pappas & Sophia & $\begin{array}{l}\text { executive } \\
\text { director of } \\
\text { Early } \\
\text { Childhood } \\
\text { Education }\end{array}$ & $\begin{array}{l}\text { NYC Department of } \\
\text { Education }\end{array}$ & $\begin{array}{l}\text { NYC } \\
\text { education } \\
\text { official }\end{array}$ \\
\hline
\end{tabular}


NEWS FRAMING OF UNIVERSAL PRE-K ROLLOUT IN NYC

\begin{tabular}{|c|c|c|c|c|c|}
\hline CHALK20A & Wallack & Josh & $\begin{array}{l}\text { chief strategy } \\
\text { officer }\end{array}$ & $\begin{array}{l}\text { NYC Department of } \\
\text { Education }\end{array}$ & $\begin{array}{l}\text { NYC } \\
\text { education } \\
\text { official }\end{array}$ \\
\hline CHALK20B & Fariña & Carmen & $\begin{array}{l}\text { schools } \\
\text { chancellor }\end{array}$ & $\begin{array}{l}\text { NYC Department of } \\
\text { Education }\end{array}$ & $\begin{array}{l}\text { NYC } \\
\text { education } \\
\text { official }\end{array}$ \\
\hline CHALK22A & Fariña & Carmen & $\begin{array}{l}\text { schools } \\
\text { chancellor }\end{array}$ & $\begin{array}{l}\text { NYC Department of } \\
\text { Education }\end{array}$ & $\begin{array}{l}\text { NYC } \\
\text { education } \\
\text { official }\end{array}$ \\
\hline CHALK23A & Cuomo & Andrew & governor & State of New York & state official \\
\hline CHALK23B & de Blasio & Bill & mayor & NYC Mayor's Office & NYC official \\
\hline CHALK23C & Krueger & Liz & senator & New York State Senate & state official \\
\hline CHALK24A & Pappas & Sophia & $\begin{array}{l}\text { executive } \\
\text { director of } \\
\text { Early } \\
\text { Childhood } \\
\text { Education }\end{array}$ & $\begin{array}{l}\text { NYC Department of } \\
\text { Education }\end{array}$ & $\begin{array}{l}\text { NYC } \\
\text { education } \\
\text { official }\end{array}$ \\
\hline CHALK24B & de Blasio & Bill & mayor & NYC Mayor's Office & NYC official \\
\hline CHALK24C & Moskowitz & Eva & & Success Academies & $\begin{array}{l}\text { principal/admi } \\
\text { nistrator }\end{array}$ \\
\hline CHALK24D & Fariña & Carmen & $\begin{array}{l}\text { schools } \\
\text { chancellor }\end{array}$ & $\begin{array}{l}\text { NYC Department of } \\
\text { Education }\end{array}$ & $\begin{array}{l}\text { NYC } \\
\text { education } \\
\text { official }\end{array}$ \\
\hline CHALK25A & de Blasio & Bill & mayor & NYC Mayor's Office & NYC official \\
\hline CHALK25B & Norr & Selena & blogger & & parent \\
\hline CHALK25C & Gumbiner & Liz & blogger & & parent \\
\hline CHALK25D & Schneider & Matt & blogger & & parent \\
\hline CHALK25E & Wallack & Josh & \multicolumn{2}{|c|}{ chief strategy officer } & $\begin{array}{l}\text { NYC } \\
\text { education } \\
\text { official }\end{array}$ \\
\hline CHALK25F & Coleman & Kimberly & blogger & & parent \\
\hline CHALK26A & Fariña & Carmen & $\begin{array}{l}\text { schools } \\
\text { chancellor }\end{array}$ & $\begin{array}{l}\text { NYC Department of } \\
\text { Education }\end{array}$ & $\begin{array}{l}\text { NYC } \\
\text { education } \\
\text { official }\end{array}$ \\
\hline CHALK27A & de Blasio & Bill & mayor & NYC Mayor's Office & NYC official \\
\hline CHALK27B & Shorris & Anthony & "top deputy" & NYC Mayor's Office & NYC official \\
\hline CHALK27C & Stringer & Scott & comptroller & City of New York & NYC official \\
\hline CHALK27D & Cuomo & Andrew & governor & State of New York & state official \\
\hline CHALK28A & Skelos & Dean & senator & New York State Senate & state official \\
\hline CHALK28B & Silver & Sheldon & $\begin{array}{l}\text { assembly } \\
\text { speaker }\end{array}$ & $\begin{array}{l}\text { New York State } \\
\text { Assembly }\end{array}$ & state official \\
\hline CHALK28C & Nolan & Catherine & assemblyman & $\begin{array}{l}\text { New York State } \\
\text { Assembly }\end{array}$ & state official \\
\hline CHALK29A & de Blasio & Bill & mayor & NYC Mayor's Office & NYC official \\
\hline CHALK31A & Way & Amy & $\begin{array}{l}\text { executive } \\
\text { director of } \\
\text { teacher } \\
\text { recruitment }\end{array}$ & $\begin{array}{l}\text { NYC Department of } \\
\text { Education }\end{array}$ & $\begin{array}{l}\text { NYC } \\
\text { education } \\
\text { official }\end{array}$ \\
\hline CHALK31B & Nocenti & David & $\begin{array}{l}\text { executive } \\
\text { director }\end{array}$ & $\begin{array}{l}\text { Union Settlement } \\
\text { Association }\end{array}$ & $\begin{array}{l}\text { principal/admi } \\
\text { nistrator }\end{array}$ \\
\hline
\end{tabular}


NEWS FRAMING OF UNIVERSAL PRE-K ROLLOUT IN NYC

\begin{tabular}{|c|c|c|c|c|c|}
\hline CHALK31C & Pappas & Sophia & $\begin{array}{l}\text { executive } \\
\text { director of } \\
\text { Early } \\
\text { Childhood } \\
\text { Education }\end{array}$ & $\begin{array}{l}\text { NYC Department of } \\
\text { Education }\end{array}$ & $\begin{array}{l}\text { NYC } \\
\text { education } \\
\text { official }\end{array}$ \\
\hline CHALK32A & de Blasio & Bill & mayor & NYC Mayor's Office & NYC official \\
\hline CHALK34A & Silver & Sheldon & $\begin{array}{l}\text { assembly } \\
\text { speaker }\end{array}$ & $\begin{array}{l}\text { New York State } \\
\text { Assembly }\end{array}$ & state official \\
\hline CHALK34B & de Blasio & Bill & mayor & NYC Mayor's Office & NYC official \\
\hline CHALK35A & de Blasio & Bill & mayor & NYC Mayor's Office & NYC official \\
\hline CHALK35B & Buery & Richard & deputy mayor & NYC Mayor's Office & NYC official \\
\hline CHALK36A & de Blasio & Bill & mayor & NYC Mayor's Office & NYC official \\
\hline CHALK37A & Fariña & Carmen & $\begin{array}{l}\text { schools } \\
\text { chancellor }\end{array}$ & $\begin{array}{l}\text { NYC Department of } \\
\text { Education }\end{array}$ & $\begin{array}{l}\text { NYC } \\
\text { education } \\
\text { official }\end{array}$ \\
\hline CHALK38A & Mone & Kathleen & board member & $\begin{array}{l}\text { Ethical Community } \\
\text { Charter School }\end{array}$ & $\begin{array}{l}\text { other education } \\
\text { official }\end{array}$ \\
\hline CHALK38B & Fariña & Carmen & $\begin{array}{l}\text { schools } \\
\text { chancellor }\end{array}$ & $\begin{array}{l}\text { NYC Department of } \\
\text { Education }\end{array}$ & $\begin{array}{l}\text { NYC } \\
\text { education } \\
\text { official }\end{array}$ \\
\hline CHALK38C & Kaye & Devora & spokesman & $\begin{array}{l}\text { NYC Department of } \\
\text { Education }\end{array}$ & $\begin{array}{l}\text { NYC } \\
\text { education } \\
\text { official }\end{array}$ \\
\hline CHALK39A & Tallon & James & regent & $\begin{array}{l}\text { New York State Board } \\
\text { of Regents }\end{array}$ & $\begin{array}{l}\text { other education } \\
\text { official }\end{array}$ \\
\hline CHALK39B & King & John & $\begin{array}{l}\text { state schools } \\
\text { chief }\end{array}$ & $\begin{array}{l}\text { New York State } \\
\text { Department of } \\
\text { Education }\end{array}$ & $\begin{array}{l}\text { other education } \\
\text { official }\end{array}$ \\
\hline CHALK39C & Tisch & Merryl & chancellor & $\begin{array}{l}\text { New York State Board } \\
\text { of Regents }\end{array}$ & $\begin{array}{l}\text { other education } \\
\text { official }\end{array}$ \\
\hline CHALK39D & Slentz & Ken & $\begin{array}{l}\text { deputy } \\
\text { commissioner }\end{array}$ & $\begin{array}{l}\text { New York State } \\
\text { Department of } \\
\text { Education }\end{array}$ & $\begin{array}{l}\text { other education } \\
\text { official }\end{array}$ \\
\hline CHALK39E & Kaye & Devora & spokesman & $\begin{array}{l}\text { NYC Department of } \\
\text { Education }\end{array}$ & $\begin{array}{l}\text { NYC } \\
\text { education } \\
\text { official }\end{array}$ \\
\hline CHALK41A & Sardi & Gina & head & $\begin{array}{l}\text { New York City } \\
\text { Montessori Charter } \\
\text { School }\end{array}$ & $\begin{array}{l}\text { principal/admi } \\
\text { nistrator }\end{array}$ \\
\hline CHALK41B & Tettonis & Christina & principal & Hellenic Charter School & $\begin{array}{l}\text { principal/admi } \\
\text { nistrator }\end{array}$ \\
\hline CHALK41C & Merriman & James & $\mathrm{CEO}$ & $\begin{array}{l}\text { New York City Charter } \\
\text { School Center }\end{array}$ & $\begin{array}{l}\text { advocacy } \\
\text { organization }\end{array}$ \\
\hline CHALK42A & de Blasio & Bill & mayor & NYC Mayor's Office & NYC official \\
\hline CHALK42B & Buery & Richard & deputy mayor & NYC Mayor's Office & NYC official \\
\hline CHALK43A & de Blasio & Bill & mayor & NYC Mayor's Office & NYC official \\
\hline CHALK44A & Friedman & Jodi & $\begin{array}{l}\text { assistant } \\
\text { principal }\end{array}$ & PS 63 STAR Academy & $\begin{array}{l}\text { principal/admi } \\
\text { nistrator }\end{array}$ \\
\hline CHALK44B & Cameron & Darlene & principal & PS 63 STAR Academy & $\begin{array}{l}\text { principal/admi } \\
\text { nistrator }\end{array}$ \\
\hline CHALK44C & Kent & Audrey & $\begin{array}{l}\text { speech } \\
\text { therapist }\end{array}$ & PS 63 STAR Academy & other \\
\hline
\end{tabular}


NEWS FRAMING OF UNIVERSAL PRE-K ROLLOUT IN NYC

\begin{tabular}{|c|c|c|c|c|c|}
\hline CHALK44D & Bowles & Kevyn & principal & $\begin{array}{l}\text { New Bridges } \\
\text { Elementary }\end{array}$ & $\begin{array}{l}\text { principal/admi } \\
\text { nistrator }\end{array}$ \\
\hline CHALK44E & Sclavos & Jayne & $\begin{array}{l}\text { parent } \\
\text { coordinator }\end{array}$ & PS 115 & other \\
\hline CHALK44F & Carabello & Leslie & $\begin{array}{l}\text { councilmembe } \\
\mathrm{r}\end{array}$ & $\begin{array}{l}\text { Citywide Council on } \\
\text { Special Education }\end{array}$ & parent \\
\hline CHALK45A & de Blasio & Bill & mayor & NYC Mayor's Office & NYC official \\
\hline CHALK46A & Cameron & Darlene & principal & PS 63 STAR Academy & $\begin{array}{l}\text { principal/admi } \\
\text { nistrator }\end{array}$ \\
\hline CHALK46B & Sclavos & Jayne & $\begin{array}{l}\text { parent } \\
\text { coordinator }\end{array}$ & PS 115 & other \\
\hline CHALK46C & $\begin{array}{l}\text { Villavicenci } \\
\text { o }\end{array}$ & Christina & principal & PS 197 & $\begin{array}{l}\text { principal/admi } \\
\text { nistrator }\end{array}$ \\
\hline CHALK46D & Davenport & Roberta & principal & PS 307 & $\begin{array}{l}\text { principal/admi } \\
\text { nistrator }\end{array}$ \\
\hline CHALK46E & Bowles & Kevyn & principal & $\begin{array}{l}\text { New Bridges } \\
\text { Elementary }\end{array}$ & $\begin{array}{l}\text { principal/admi } \\
\text { nistrator }\end{array}$ \\
\hline CHALK47A & Leb & Jeff & $\begin{array}{l}\text { New York } \\
\text { State Director }\end{array}$ & Orthodox Union & other \\
\hline CHALK47B & Lieberman & Donna & $\begin{array}{l}\text { executive } \\
\text { director }\end{array}$ & $\begin{array}{l}\text { New York Civil } \\
\text { Liberties Union }\end{array}$ & $\begin{array}{l}\text { advocacy } \\
\text { organization }\end{array}$ \\
\hline CHALK47C & Greenbaum & Shulem & director & $\begin{array}{l}\text { Brios Square of } \\
\text { Williamsburg }\end{array}$ & $\begin{array}{l}\text { principal/admi } \\
\text { nistrator }\end{array}$ \\
\hline CHALK47D & & & $\begin{array}{l}\text { unnamed } \\
\text { director }\end{array}$ & $\begin{array}{l}\text { undisclosed Jewish } \\
\text { daycare center }\end{array}$ & $\begin{array}{l}\text { principal/admi } \\
\text { nistrator }\end{array}$ \\
\hline CHALK47E & Zweibel & David & rabbi & Agudath Israel & other \\
\hline CHALK47F & Friedman & Chany & parent & & parent \\
\hline CHALK47G & de Blasio & Bill & mayor & NYC Mayor's Office & NYC official \\
\hline CHALK47H & Wheaton & Pamela & $\begin{array}{l}\text { managing } \\
\text { editor }\end{array}$ & InsideSchools & other \\
\hline CHALK47I & Kaye & Devora & spokesman & $\begin{array}{l}\text { NYC Department of } \\
\text { Education }\end{array}$ & $\begin{array}{l}\text { NYC } \\
\text { education } \\
\text { official }\end{array}$ \\
\hline CHALK48A & Buery & Richard & deputy mayor & NYC Mayor's Office & NYC official \\
\hline CHALK49A & Gauthier & Stacey & principal & $\begin{array}{l}\text { Renaissance Charter } \\
\text { School }\end{array}$ & $\begin{array}{l}\text { principal/admi } \\
\text { nistrator }\end{array}$ \\
\hline CHALK49B & Sardi & Gina & head & $\begin{array}{l}\text { New York City } \\
\text { Montessori Charter } \\
\text { School }\end{array}$ & $\begin{array}{l}\text { principal/admi } \\
\text { nistrator }\end{array}$ \\
\hline CHALK49C & Merriman & James & $\mathrm{CEO}$ & $\begin{array}{l}\text { New York City Charter } \\
\text { School Center }\end{array}$ & $\begin{array}{l}\text { advocacy } \\
\text { organization }\end{array}$ \\
\hline CHALK49D & Tettonis & Christina & principal & Hellenic Charter School & $\begin{array}{l}\text { principal/admi } \\
\text { nistrator }\end{array}$ \\
\hline CHALK50A & Dickson & Sade & $\begin{array}{l}\text { enrollment } \\
\text { specialist }\end{array}$ & Saratoga Family Inn & other \\
\hline CHALK50B & Daniels & Jodi & teacher & Saratoga Family Inn & $\begin{array}{l}\text { classroom } \\
\text { teacher }\end{array}$ \\
\hline CHALK52A & Fariña & Carmen & $\begin{array}{l}\text { schools } \\
\text { chancellor }\end{array}$ & $\begin{array}{l}\text { NYC Department of } \\
\text { Education }\end{array}$ & $\begin{array}{l}\text { NYC } \\
\text { education } \\
\text { official }\end{array}$ \\
\hline CHALK52B & Hicks & Steven & $\begin{array}{l}\text { senior policy } \\
\text { advisor }\end{array}$ & $\begin{array}{l}\text { U.S. Department of } \\
\text { Education }\end{array}$ & $\begin{array}{l}\text { other education } \\
\text { official }\end{array}$ \\
\hline
\end{tabular}


NEWS FRAMING OF UNIVERSAL PRE-K ROLLOUT IN NYC

\begin{tabular}{|c|c|c|c|c|c|}
\hline CHALK52D & Ayala & Celia & CEO & $\begin{array}{l}\text { Los Angeles Universal } \\
\text { Preschool }\end{array}$ & $\begin{array}{l}\text { other education } \\
\text { official }\end{array}$ \\
\hline CHALK53A & de Blasio & Bill & mayor & NYC Mayor's Office & NYC official \\
\hline CHALK53B & Holt & Alexander & & $\begin{array}{l}\text { New America } \\
\text { Foundation }\end{array}$ & think tank \\
\hline CHALK53C & de Blasio & Bill & mayor & NYC Mayor's Office & NYC official \\
\hline CHALK54A & Buery & Richard & deputy mayor & NYC Mayor's Office & NYC official \\
\hline CHALK54B & & Ana & \multicolumn{2}{|c|}{ unnamed mother } & parent \\
\hline CHALK54C & Pelchar & Francyne & \multicolumn{2}{|l|}{ commenter } & other \\
\hline CHALK55A & & & \multicolumn{2}{|l|}{ unnamed teacher } & $\begin{array}{l}\text { classroom } \\
\text { teacher }\end{array}$ \\
\hline CHALK55B & $\begin{array}{l}\text { Polakow- } \\
\text { Suransky }\end{array}$ & Shael & president & $\begin{array}{l}\text { Bank Street College of } \\
\text { Education }\end{array}$ & $\begin{array}{l}\text { college } \\
\text { administrator }\end{array}$ \\
\hline CHALK55C & Roach & Virginia & dean & Bank Street & $\begin{array}{l}\text { college } \\
\text { administrator }\end{array}$ \\
\hline CHALK55D & Cervantes & James & $\begin{array}{l}\text { assistant } \\
\text { teacher }\end{array}$ & Alpha Academy & $\begin{array}{l}\text { classroom } \\
\text { teacher }\end{array}$ \\
\hline CHALK56A & de Blasio & Bill & mayor & NYC Mayor's Office & NYC official \\
\hline CHALK56B & Fariña & Carmen & $\begin{array}{l}\text { schools } \\
\text { chancellor }\end{array}$ & $\begin{array}{l}\text { NYC Department of } \\
\text { Education }\end{array}$ & $\begin{array}{l}\text { NYC } \\
\text { education } \\
\text { official }\end{array}$ \\
\hline CHALK56C & McBride & Tha & teacher & & $\begin{array}{l}\text { classroom } \\
\text { teacher }\end{array}$ \\
\hline CHALK57A & Buery & Richard & deputy mayor & NYC Mayor's Office & NYC official \\
\hline CHALK57B & Bassett & Mary & commissioner & $\begin{array}{l}\text { Department of Health } \\
\& \text { Mental Hygiene }\end{array}$ & NYC official \\
\hline CHALK58A & Markarian & Emily & trainer & & $\begin{array}{l}\text { classroom } \\
\text { teacher }\end{array}$ \\
\hline CHALK58B & Stipek & Deborah & dean & $\begin{array}{l}\text { Stanford University } \\
\text { Graduate School of } \\
\text { Education }\end{array}$ & $\begin{array}{l}\text { college } \\
\text { administrator }\end{array}$ \\
\hline CHALK58C & $\begin{array}{l}\text { Olu } \\
\text { Hamilton }\end{array}$ & Maria & $\begin{array}{l}\text { teaching } \\
\text { assistant }\end{array}$ & MS 394 & $\begin{array}{l}\text { classroom } \\
\text { teacher }\end{array}$ \\
\hline CHALK58D & Falk & Beverly & director & City College & $\begin{array}{l}\text { college } \\
\text { administrator }\end{array}$ \\
\hline CHALK58E & Garcia & Betty & teacher & & $\begin{array}{l}\text { classroom } \\
\text { teacher }\end{array}$ \\
\hline CHALK58F & Bornfreund & Laura & deputy director & $\begin{array}{l}\text { New America } \\
\text { Foundation }\end{array}$ & think tank \\
\hline CHALK58G & Pollak & Lily & aspiring teacher & & $\begin{array}{l}\text { classroom } \\
\text { teacher }\end{array}$ \\
\hline CHALK58H & Cleary & Sherry & $\begin{array}{l}\text { executive } \\
\text { director }\end{array}$ & $\begin{array}{l}\text { CUNY/New York City } \\
\text { Early Childhood } \\
\text { Professional } \\
\text { Development Institute }\end{array}$ & $\begin{array}{l}\text { college } \\
\text { administrator }\end{array}$ \\
\hline CHALK58I & Clark & Alisa & teacher & 14th St Y & $\begin{array}{l}\text { classroom } \\
\text { teacher }\end{array}$ \\
\hline CHALK58J & Lescure & Rebecca & teacher & PS 282 & $\begin{array}{l}\text { classroom } \\
\text { teacher }\end{array}$ \\
\hline CHALK58K & Soto & Esther & teacher & & $\begin{array}{l}\text { classroom } \\
\text { teacher }\end{array}$ \\
\hline
\end{tabular}




\section{NEWS FRAMING OF UNIVERSAL PRE-K ROLLOUT IN NYC}

\begin{tabular}{|c|c|c|c|c|c|}
\hline CHALK59A & Cleary & Sherry & $\begin{array}{l}\text { executive } \\
\text { director }\end{array}$ & $\begin{array}{l}\text { CUNY/New York City } \\
\text { Early Childhood } \\
\text { Professional } \\
\text { Development Institute }\end{array}$ & $\begin{array}{l}\text { college } \\
\text { administrator }\end{array}$ \\
\hline CHALK59B & Bornfreund & Laura & deputy director & $\begin{array}{l}\text { New America } \\
\text { Foundation }\end{array}$ & think tank \\
\hline CHALK59C & Olhson & Cheryl & $\begin{array}{l}\text { early } \\
\text { childhood } \\
\text { division }\end{array}$ & D.C. Public Schools & $\begin{array}{l}\text { other education } \\
\text { official }\end{array}$ \\
\hline CHALK59D & Friedman & Jodi & $\begin{array}{l}\text { assistant } \\
\text { principal }\end{array}$ & PS 63 STAR Academy & $\begin{array}{l}\text { principal/admi } \\
\text { nistrator }\end{array}$ \\
\hline CHALK59E & Bowles & Kevyn & principal & $\begin{array}{l}\text { New Bridges } \\
\text { Elementary }\end{array}$ & $\begin{array}{l}\text { principal/admi } \\
\text { nistrator }\end{array}$ \\
\hline CHALK59F & Allanbrook & Anna & principal & Brooklyn New School & $\begin{array}{l}\text { principal/admi } \\
\text { nistrator }\end{array}$ \\
\hline CHALK60A & Stringer & Scott & comptroller & City of New York & NYC official \\
\hline CHALK61A & de Blasio & Bill & mayor & NYC Mayor's Office & NYC official \\
\hline CHALK61B & Bonano & Rebecca & $\begin{array}{l}\text { director of } \\
\text { UPK }\end{array}$ & $\begin{array}{l}\text { Fabiana Day Care } \\
\text { Academy }\end{array}$ & $\begin{array}{l}\text { principal/admi } \\
\text { nistrator }\end{array}$ \\
\hline CHALK62A & Buery & Richard & deputy mayor & NYC Mayor's Office & NYC official \\
\hline CHALK62B & Merriman & James & CEO & $\begin{array}{l}\text { New York City Charter } \\
\text { School Center }\end{array}$ & $\begin{array}{l}\text { advocacy } \\
\text { organization }\end{array}$ \\
\hline CHALK62C & Boyd & Tenicka & $\begin{array}{l}\text { parent } \\
\text { organizer }\end{array}$ & StudentsFirstNY & $\begin{array}{l}\text { advocacy } \\
\text { organization }\end{array}$ \\
\hline CHALK62D & Mulgrew & Michael & president & $\begin{array}{l}\text { United Federation of } \\
\text { Teachers }\end{array}$ & teachers union \\
\hline CHALK62E & Tisch & Merryl & chancellor & $\begin{array}{l}\text { New York State Board } \\
\text { of Regents }\end{array}$ & $\begin{array}{l}\text { other education } \\
\text { official }\end{array}$ \\
\hline CHALK63A & Bassett & Mary & commissioner & $\begin{array}{l}\text { Department of Health } \\
\& \text { Mental Hygiene }\end{array}$ & NYC official \\
\hline CHALK64A & Eng & Kelly & mother & & parent \\
\hline CHALK64B & de Blasio & Bill & mayor & NYC Mayor's Office & NYC official \\
\hline CHALK64C & Fariña & Carmen & $\begin{array}{l}\text { schools } \\
\text { chancellor }\end{array}$ & $\begin{array}{l}\text { NYC Department of } \\
\text { Education }\end{array}$ & $\begin{array}{l}\text { NYC } \\
\text { education } \\
\text { official }\end{array}$ \\
\hline CHALK64D & Powell & Khadija & teacher & Grand Street Settlement & $\begin{array}{l}\text { classroom } \\
\text { teacher }\end{array}$ \\
\hline CHALK64E & Ortega & Abdul & student & & student \\
\hline CHALK64F & Chen & Catori & student & & student \\
\hline CHALK66A & & & \multicolumn{2}{|c|}{ unnamed principal } & $\begin{array}{l}\text { principal/admi } \\
\text { nistrator }\end{array}$ \\
\hline CHALK67A & Fuller & Bruce & researcher & $\begin{array}{l}\text { University of } \\
\text { California, Berkeley }\end{array}$ & $\begin{array}{l}\text { academic/instit } \\
\text { utionally- } \\
\text { affiliated } \\
\text { researcher }\end{array}$ \\
\hline CHALK67B & Norvell & Wiley & spokesman & NYC Mayor's Office & NYC official \\
\hline CHALK67B & Noguera & Pedro & professor & New York University & $\begin{array}{l}\text { academic/instit } \\
\text { utionally- } \\
\text { affiliated } \\
\text { researcher }\end{array}$ \\
\hline CHALK67C & Cappio & Moria & $\begin{array}{l}\text { vice president } \\
\text { for early }\end{array}$ & Children's Aid Society & $\begin{array}{l}\text { principal/admi } \\
\text { nistrator }\end{array}$ \\
\hline
\end{tabular}


NEWS FRAMING OF UNIVERSAL PRE-K ROLLOUT IN NYC

\begin{tabular}{|c|c|c|c|c|c|}
\hline & & & $\begin{array}{l}\text { childhood } \\
\text { programs }\end{array}$ & & \\
\hline CHALK67C & Dunn & Tom & spokesman & $\begin{array}{l}\text { New York State } \\
\text { Department of } \\
\text { Education }\end{array}$ & $\begin{array}{l}\text { other education } \\
\text { official }\end{array}$ \\
\hline CHALK68D & Gassawan & Bernard & principal & $\begin{array}{l}\text { Boys and Girls High } \\
\text { School }\end{array}$ & $\begin{array}{l}\text { principal/admi } \\
\text { nistrator }\end{array}$ \\
\hline CHALK68E & & & $\begin{array}{l}\text { unnamed } \\
\text { spokesman }\end{array}$ & $\begin{array}{l}\text { NYC Department of } \\
\text { Education }\end{array}$ & $\begin{array}{l}\text { NYC } \\
\text { education } \\
\text { official } \\
\end{array}$ \\
\hline CHALK69A & de Blasio & Bill & mayor & NYC Mayor's Office & NYC official \\
\hline CHALK70A & Buery & Richard & deputy mayor & NYC Mayor's Office & NYC official \\
\hline CHALK70B & Mokim & $\begin{array}{l}\text { Zalyka } \\
\text { Maria }\end{array}$ & $\begin{array}{l}\text { founding ELL } \\
\text { department } \\
\text { leader }\end{array}$ & MESA Charter & $\begin{array}{l}\text { classroom } \\
\text { teacher }\end{array}$ \\
\hline CHALK70C & Mulgrew & Michael & president & $\begin{array}{l}\text { United Federation of } \\
\text { Teachers }\end{array}$ & teachers union \\
\hline CHALK70D & Mackert & Noah & $\begin{array}{l}\text { 7th grade } \\
\text { English } \\
\text { teacher }\end{array}$ & $\begin{array}{l}\text { Democracy Prep } \\
\text { Charter Middle }\end{array}$ & $\begin{array}{l}\text { classroom } \\
\text { teacher }\end{array}$ \\
\hline CHALK70E & Sprowal & Karen & mother & & parent \\
\hline NYT02A & de Blasio & Bill & mayor & NYC Mayor's Office & NYC official \\
\hline NYT02B & & & \multicolumn{2}{|l|}{ unnamed pastor } & other \\
\hline NYT02C & Taylor & Justina & student & & student \\
\hline NYT02D & Stringer & Scott & comptroller & City of New York & NYC official \\
\hline NYT02E & Ramana & Ramya & poet & & other \\
\hline NYT02F & Jones & Letitia & $\begin{array}{l}\text { public } \\
\text { advocate }\end{array}$ & City of New York & NYC official \\
\hline NYT03A & de Blasio & Bill & mayor & NYC Mayor's Office & NYC official \\
\hline NYT03B & Wyly & Elvin & geographer & $\begin{array}{l}\text { University of British } \\
\text { Columbia }\end{array}$ & $\begin{array}{l}\text { academic/instit } \\
\text { utionally- } \\
\text { affiliated } \\
\text { researcher }\end{array}$ \\
\hline NYT03C & & & \multicolumn{2}{|c|}{ unnamed committee member } & NYC official \\
\hline NYT03D & Soury & Lonnie & $\begin{array}{l}\text { former } \\
\text { spokesman }\end{array}$ & Dinkins administration & NYC official \\
\hline NYT03E & Scott & Denise & $\begin{array}{l}\text { executive VP } \\
\text { of } \\
\text { programming }\end{array}$ & $\begin{array}{l}\text { Local Initiatives } \\
\text { Support Corp. }\end{array}$ & $\begin{array}{l}\text { advocacy } \\
\text { organization }\end{array}$ \\
\hline NYT03F & Beinart & Peter & \multicolumn{2}{|l|}{ liberal essayist } & other \\
\hline NYT03G & & & \multicolumn{2}{|c|}{ unnamed long-serving liberal } & NYC official \\
\hline NYT04A & Cuomo & Andrew & governor & State of New York & state official \\
\hline NYT04B & Brodsky & Richard & $\begin{array}{l}\text { former } \\
\text { assemblyman }\end{array}$ & $\begin{array}{l}\text { New York State } \\
\text { Assembly }\end{array}$ & state official \\
\hline NYT04C & de Blasio & Bill & mayor & NYC Mayor's Office & NYC official \\
\hline NYT04D & Barnett & Steve & director & $\begin{array}{l}\text { National Institute for } \\
\text { Early Education } \\
\text { Research }\end{array}$ & $\begin{array}{l}\text { academic/instit } \\
\text { utionally- } \\
\text { affiliated } \\
\text { researcher }\end{array}$ \\
\hline NYT04E & Gelinas & Nicole & senior fellow & $\begin{array}{l}\text { Manhattan Institute for } \\
\text { Public Policy }\end{array}$ & think tank \\
\hline
\end{tabular}


NEWS FRAMING OF UNIVERSAL PRE-K ROLLOUT IN NYC

\begin{tabular}{|c|c|c|c|c|c|}
\hline NYT05A & Cuomo & Andrew & governor & State of New York & state official \\
\hline NYT05B & de Blasio & Bill & mayor & NYC Mayor's Office & NYC official \\
\hline NYT05C & Skelos & Dean & senator & New York State Senate & state official \\
\hline NYT06A & & & advisory panel & Gov. Andrew Cuomo & state official \\
\hline NYT06B & Mulgrew & Michael & president & $\begin{array}{l}\text { United Federation of } \\
\text { Teachers }\end{array}$ & teachers union \\
\hline NYT06C & de Blasio & Bill & mayor & NYC Mayor's Office & NYC official \\
\hline NYT06D & Moskowitz & Eva & & Success Academies & $\begin{array}{l}\text { principal/admi } \\
\text { nistrator }\end{array}$ \\
\hline NYT06E & Ballen & Morty & chief executive & Explore Schools & $\begin{array}{l}\text { principal/admi } \\
\text { nistrator }\end{array}$ \\
\hline NYT06F & Marx & Anthony & president & $\begin{array}{l}\text { New York Public } \\
\text { Library }\end{array}$ & other \\
\hline NYT08A & de Blasio & Bill & mayor & NYC Mayor's Office & NYC official \\
\hline NYT09A & Cuomo & Andrew & governor & State of New York & state official \\
\hline NYT09B & Adams & Marti & spokeswoman & NYC Mayor's Office & NYC official \\
\hline NYT11A & de Blasio & Bill & mayor & NYC Mayor's Office & NYC official \\
\hline NYT11B & & & $\begin{array}{l}\text { unnamed } \\
\text { spokeswoman }\end{array}$ & Mayor Rahm Emanuel & $\begin{array}{l}\text { other } \\
\text { government } \\
\text { official }\end{array}$ \\
\hline NYT12A & Canada & Geoffrey & $\mathrm{CEO}$ & Harlem Children's Zone & $\begin{array}{l}\text { advocacy } \\
\text { organization }\end{array}$ \\
\hline NYT12B & Whitehurst & Grover & fellow & Brookings Institute & think tank \\
\hline NYT12C & de Blasio & Bill & mayor & NYC Mayor's Office & NYC official \\
\hline NYT12D & Abrev & Lucas & PE teacher & & $\begin{array}{l}\text { classroom } \\
\text { teacher }\end{array}$ \\
\hline NYT12E & Sanger & Stanley & superintendent & Union City Schools & $\begin{array}{l}\text { principal/admi } \\
\text { nistrator }\end{array}$ \\
\hline NYT12F & Norvell & Wiley & spokesman & NYC Mayor's Office & NYC official \\
\hline NYT12G & Nayowith & Gail & $\begin{array}{l}\text { task force } \\
\text { member }\end{array}$ & NYC Mayor's Office & NYC official \\
\hline NYT13A & de Blasio & Bill & mayor & NYC Mayor's Office & NYC official \\
\hline NYT13B & Martins & Jack & senator & New York State Senate & state official \\
\hline NYT13C & Cuomo & Andrew & governor & State of New York & state official \\
\hline NYT13D & Silver & Sheldon & $\begin{array}{l}\text { assembly } \\
\text { speaker }\end{array}$ & $\begin{array}{l}\text { New York State } \\
\text { Assembly }\end{array}$ & state official \\
\hline NYT13E & Takanishi & Ruby & $\begin{array}{l}\text { former } \\
\text { president }\end{array}$ & $\begin{array}{l}\text { Foundation for Child } \\
\text { Development }\end{array}$ & $\begin{array}{l}\text { advocacy } \\
\text { organization }\end{array}$ \\
\hline NYT13F & Rebell & Michael & professor & $\begin{array}{l}\text { Columbia Teachers } \\
\text { College }\end{array}$ & $\begin{array}{l}\text { academic/instit } \\
\text { utionally- } \\
\text { affiliated } \\
\text { researcher }\end{array}$ \\
\hline NYT14A & King & John & $\begin{array}{l}\text { education } \\
\text { commissioner }\end{array}$ & $\begin{array}{l}\text { New York State } \\
\text { Department of } \\
\text { Education }\end{array}$ & $\begin{array}{l}\text { other education } \\
\text { official }\end{array}$ \\
\hline NYT14B & de Blasio & Bill & mayor & NYC Mayor's Office & NYC official \\
\hline NYT14C & Wang & Matt & spokesman & State of New York & state official \\
\hline NYT15A & Kitteredge & Jeremiah & $\begin{array}{l}\text { executive } \\
\text { director }\end{array}$ & $\begin{array}{l}\text { Families for Excellent } \\
\text { Schools }\end{array}$ & $\begin{array}{l}\text { advocacy } \\
\text { organization }\end{array}$ \\
\hline
\end{tabular}


NEWS FRAMING OF UNIVERSAL PRE-K ROLLOUT IN NYC

\begin{tabular}{|c|c|c|c|c|c|}
\hline NYT15B & Fariña & Carmen & $\begin{array}{l}\text { schools } \\
\text { chancellor }\end{array}$ & $\begin{array}{l}\text { NYC Department of } \\
\text { Education }\end{array}$ & $\begin{array}{l}\text { NYC } \\
\text { education } \\
\text { official }\end{array}$ \\
\hline NYT15C & Merriman & James & $\mathrm{CEO}$ & $\begin{array}{l}\text { New York City Charter } \\
\text { School Center }\end{array}$ & $\begin{array}{l}\text { advocacy } \\
\text { organization }\end{array}$ \\
\hline NYT16A & Greer & Christina & professor & Fordham University & $\begin{array}{l}\text { academic/instit } \\
\text { utionally- } \\
\text { affiliated } \\
\text { researcher }\end{array}$ \\
\hline NYT16B & Gold & Josh & labor organizer & de Blasio campaign & other \\
\hline NYT16C & & & \multicolumn{2}{|l|}{ labor leader } & other \\
\hline NYT16D & Howard & Brett & \multicolumn{2}{|c|}{ Democratic activist } & other \\
\hline NYT16E & Pebbles & Donahue & \multicolumn{2}{|c|}{ real estate executive } & other \\
\hline NYT16F & Lerner & Susan & $\begin{array}{l}\text { executive } \\
\text { director }\end{array}$ & $\begin{array}{l}\text { Common Cause New } \\
\text { York }\end{array}$ & $\begin{array}{l}\text { advocacy } \\
\text { organization }\end{array}$ \\
\hline NYT16G & Klein & Jeff & co-leader & New York State Senate & state official \\
\hline NYT17A & Canada & Geoffrey & CEO & Harlem Children's Zone & $\begin{array}{l}\text { advocacy } \\
\text { organization }\end{array}$ \\
\hline NYT17B & $\begin{array}{l}\text { Williams- } \\
\text { Isom }\end{array}$ & Anne & $\begin{array}{l}\text { chief operating } \\
\text { officer }\end{array}$ & Harlem Children's Zone & $\begin{array}{l}\text { advocacy } \\
\text { organization }\end{array}$ \\
\hline NYT18A & de Blasio & Bill & mayor & NYC Mayor's Office & NYC official \\
\hline NYT18B & Cuomo & Andrew & governor & State of New York & state official \\
\hline NYT20A & Dyster & Paul & \multicolumn{2}{|c|}{ mayor of Niagra Falls } & $\begin{array}{l}\text { other } \\
\text { government } \\
\text { official }\end{array}$ \\
\hline NYT20B & Cuomo & Andrew & governor & State of New York & state official \\
\hline NYT20C & Easton & Billy & $\begin{array}{l}\text { executive } \\
\text { director }\end{array}$ & $\begin{array}{l}\text { Alliance for Quality } \\
\text { Education }\end{array}$ & $\begin{array}{l}\text { advocacy } \\
\text { organization }\end{array}$ \\
\hline NYT20D & Spano & Michael & \multicolumn{2}{|c|}{ mayor of Yonkers } & $\begin{array}{l}\text { other } \\
\text { government } \\
\text { official }\end{array}$ \\
\hline NYT20E & Breslin & Kate & $\begin{array}{l}\text { president \& } \\
\text { CEO }\end{array}$ & $\begin{array}{l}\text { Schuyler Center for } \\
\text { Analysis \& Advocacy }\end{array}$ & $\begin{array}{l}\text { advocacy } \\
\text { organization }\end{array}$ \\
\hline NYT21A & de Blasio & Bill & mayor & NYC Mayor's Office & NYC official \\
\hline NYT22A & de Blasio & Bill & mayor & NYC Mayor's Office & NYC official \\
\hline NYT22B & Cuomo & Andrew & governor & State of New York & state official \\
\hline NYT24A & Cuomo & Andrew & governor & State of New York & state official \\
\hline NYT24B & de Blasio & Bill & mayor & NYC Mayor's Office & NYC official \\
\hline NYT24C & Barr & Steve & founder & $\begin{array}{l}\text { Green Dot Public } \\
\text { Schools }\end{array}$ & $\begin{array}{l}\text { principal/admi } \\
\text { nistrator }\end{array}$ \\
\hline NYT24D & Moskowitz & Eva & & Success Academies & $\begin{array}{l}\text { principal/admi } \\
\text { nistrator }\end{array}$ \\
\hline NYT24E & Scott & Hope & $\begin{array}{l}\text { parent } \\
\text { association } \\
\text { leader }\end{array}$ & PS 123 & parent \\
\hline NYT24F & Fariña & Carmen & $\begin{array}{l}\text { schools } \\
\text { chancellor }\end{array}$ & $\begin{array}{l}\text { NYC Department of } \\
\text { Education }\end{array}$ & $\begin{array}{l}\text { NYC } \\
\text { education } \\
\text { official }\end{array}$ \\
\hline NYT24G & Mulgrew & Michael & president & $\begin{array}{l}\text { United Federation of } \\
\text { Teachers }\end{array}$ & teachers union \\
\hline NYT25A & Cuomo & Andrew & governor & State of New York & state official \\
\hline
\end{tabular}




\section{NEWS FRAMING OF UNIVERSAL PRE-K ROLLOUT IN NYC}

\begin{tabular}{|c|c|c|c|c|c|}
\hline NYT25B & de Blasio & Bill & mayor & NYC Mayor's Office & NYC official \\
\hline NYT26A & Skyler & Edward & $\begin{array}{l}\text { former deputy } \\
\text { mayor }\end{array}$ & $\begin{array}{l}\text { Bloomberg } \\
\text { administration }\end{array}$ & NYC official \\
\hline NYT26B & de Blasio & Bill & mayor & NYC Mayor's Office & NYC official \\
\hline NYT26C & & & $\begin{array}{l}\text { senior Cuomo } \\
\text { administration } \\
\text { official }\end{array}$ & State of New York & state official \\
\hline NYT26D & Cuomo & Andrew & governor & State of New York & state official \\
\hline NYT27A & Dolan & Timothy & $\begin{array}{l}\text { archbishop of } \\
\text { New York }\end{array}$ & Catholic Church & other \\
\hline NYT27B & de Blasio & Bill & mayor & NYC Mayor's Office & NYC official \\
\hline NYT27C & Fraser & James & professor & New York University & $\begin{array}{l}\text { academic/instit } \\
\text { utionally- } \\
\text { affiliated } \\
\text { researcher }\end{array}$ \\
\hline NYT27D & Kanofsky & Yosef & & Jewish day schools & other \\
\hline NYT30A & & Anderson & student & & student \\
\hline NYT30B & & & unnamed teache & & $\begin{array}{l}\text { classroom } \\
\text { teacher }\end{array}$ \\
\hline NYT30C & Farran & Dale & professor & Vanderbilt University & $\begin{array}{l}\text { academic/instit } \\
\text { utionally- } \\
\text { affiliated } \\
\text { researcher }\end{array}$ \\
\hline NYT30D & Weistein & Michael & $\begin{array}{l}\text { chief program } \\
\text { officer }\end{array}$ & Robin Hood & $\begin{array}{l}\text { advocacy } \\
\text { organization }\end{array}$ \\
\hline NYT30E & Morris & Pamela & director & $\begin{array}{l}\text { NYU Institute of } \\
\text { Human Development \& } \\
\text { Social Change }\end{array}$ & $\begin{array}{l}\text { academic/instit } \\
\text { utionally- } \\
\text { affiliated } \\
\text { researcher }\end{array}$ \\
\hline NYT30F & Phillips & Deborah & professor & Georgetown University & $\begin{array}{l}\text { academic/instit } \\
\text { utionally- } \\
\text { affiliated } \\
\text { researcher }\end{array}$ \\
\hline NYT31A & Mulgrew & Michael & president & $\begin{array}{l}\text { United Federation of } \\
\text { Teachers }\end{array}$ & teachers union \\
\hline NYT32A & Klein & Jeff & co-leader & New York State Senate & state official \\
\hline NYT32B & de Blasio & Bill & mayor & NYC Mayor's Office & NYC official \\
\hline NYT32C & Silver & Sheldon & $\begin{array}{l}\text { assembly } \\
\text { speaker }\end{array}$ & $\begin{array}{l}\text { New York State } \\
\text { Assembly }\end{array}$ & state official \\
\hline NYT32D & Cuomo & Andrew & governor & State of New York & state official \\
\hline NYT33A & Sheinkopf & Hank & \multicolumn{2}{|c|}{ Democratic consultant } & other \\
\hline NYT33B & Norvell & Wiley & spokesman & NYC Mayor's Office & NYC official \\
\hline NYT33C & Lipton & Bill & state director & Working Families Party & other \\
\hline NYT33D & Gyory & Bruce & \multicolumn{2}{|c|}{ political consultant } & other \\
\hline NYT33E & Finnegan & Kevin & $\begin{array}{l}\text { political } \\
\text { director }\end{array}$ & $\begin{array}{l}1199 \text { SEIU United } \\
\text { Healthcare Workers } \\
\text { East }\end{array}$ & other \\
\hline NYT33F & de Blasio & Bill & mayor & NYC Mayor's Office & NYC official \\
\hline NYT33G & & & \multicolumn{2}{|c|}{ unnamed student } & student \\
\hline NYT34A & Levitan & Dan & vice president & Berlin Rosen & other \\
\hline NYT35A & de Blasio & Bill & mayor & NYC Mayor's Office & NYC official \\
\hline
\end{tabular}


NEWS FRAMING OF UNIVERSAL PRE-K ROLLOUT IN NYC

\begin{tabular}{|c|c|c|c|c|c|}
\hline NYT35B & Cuomo & Andrew & governor & State of New York & state official \\
\hline NYT35C & Mulgrew & Michael & president & $\begin{array}{l}\text { United Federation of } \\
\text { Teachers }\end{array}$ & teachers union \\
\hline NYT35D & Ravitch & Diane & \multicolumn{2}{|c|}{ education historian } & other \\
\hline NYT35E & Dadey & Dick & $\begin{array}{l}\text { executive } \\
\text { director }\end{array}$ & Citizens Union & $\begin{array}{l}\text { advocacy } \\
\text { organization }\end{array}$ \\
\hline NYT36A & Klein & Jeff & co-leader & New York State Senate & state official \\
\hline NYT36B & Golden & Martin & senator & New York State Senate & state official \\
\hline NYT36C & Ragone & Peter & senior advisor & NYC Mayor's Office & NYC official \\
\hline NYT36D & de Blasio & Bill & mayor & NYC Mayor's Office & NYC official \\
\hline NYT36E & Sharpton & $\mathrm{Al}$ & reverend & & other \\
\hline NYT38A & McCray & Chirlane & wife & NYC Mayor's Office & NYC official \\
\hline NYT38B & Levitan & Dan & spokesman & UPKNYC & $\begin{array}{l}\text { advocacy } \\
\text { organization }\end{array}$ \\
\hline NYT39A & de Blasio & Bill & mayor & NYC Mayor's Office & NYC official \\
\hline NYT40A & Fariña & Carmen & $\begin{array}{l}\text { schools } \\
\text { chancellor }\end{array}$ & $\begin{array}{l}\text { NYC Department of } \\
\text { Education }\end{array}$ & $\begin{array}{l}\text { NYC } \\
\text { education } \\
\text { official }\end{array}$ \\
\hline NYT40B & Rebell & Michael & professor & $\begin{array}{l}\text { Columbia Teachers } \\
\text { College }\end{array}$ & $\begin{array}{l}\text { academic/instit } \\
\text { utionally- } \\
\text { affiliated } \\
\text { researcher }\end{array}$ \\
\hline NYT41A & Wolfe & Emma & longtime aide & NYC Mayor's Office & NYC official \\
\hline NYT41B & Lloyd & Emily & \multicolumn{2}{|c|}{ city administrator } & NYC official \\
\hline NYT41C & $\begin{array}{l}\text { Barrios- } \\
\text { Paoli }\end{array}$ & Lilliam & deputy mayor & NYC Mayor's Office & NYC official \\
\hline NYT41D & de Blasio & Bill & mayor & NYC Mayor's Office & NYC official \\
\hline NYT41E & Ramirez & Ursulina & chief of staff & $\begin{array}{l}\text { NYC Department of } \\
\text { Education }\end{array}$ & $\begin{array}{l}\text { NYC } \\
\text { education } \\
\text { official }\end{array}$ \\
\hline NYT41F & Glen & Alicia & deputy mayor & NYC Mayor's Office & NYC official \\
\hline NYT41G & Brosnahan & Mary & $\begin{array}{l}\text { executive } \\
\text { director }\end{array}$ & $\begin{array}{l}\text { Coalition for the } \\
\text { Homeless }\end{array}$ & $\begin{array}{l}\text { advocacy } \\
\text { organization }\end{array}$ \\
\hline NYT41H & Merriss & Peggy & $\begin{array}{l}\text { Decatur, } \\
\text { Georgia city } \\
\text { manager }\end{array}$ & $\begin{array}{l}\text { International } \\
\text { City/Council } \\
\text { Management } \\
\text { Association }\end{array}$ & $\begin{array}{l}\text { other } \\
\text { government } \\
\text { official }\end{array}$ \\
\hline NYT41I & Garcia & Kathryn & \multicolumn{2}{|c|}{ sanitation commission } & NYC official \\
\hline NYT41J & Wiley & Maya & $\begin{array}{l}\text { general } \\
\text { counsel }\end{array}$ & NYC Mayor's Office & NYC official \\
\hline NYT41K & McCray & Chirlane & wife & NYC Mayor's Office & NYC official \\
\hline NYT43A & de Blasio & Bill & mayor & NYC Mayor's Office & NYC official \\
\hline NYT43B & Markowicz & Karol & mother & & parent \\
\hline NYT43C & Levitt & Shia & mother & & parent \\
\hline NYT44A & Augustin & Mildred & \multicolumn{2}{|c|}{ daycare provider } & other \\
\hline NYT44B & Cappio & Moria & $\begin{array}{l}\text { vice president } \\
\text { for early } \\
\text { childhood } \\
\text { programs }\end{array}$ & Children's Aid Society & $\begin{array}{l}\text { principal/admi } \\
\text { nistrator }\end{array}$ \\
\hline NYT44C & Sammons & Paula & $\begin{array}{l}\text { program } \\
\text { officer }\end{array}$ & Kellogg foundation & $\begin{array}{l}\text { advocacy } \\
\text { organization }\end{array}$ \\
\hline
\end{tabular}


NEWS FRAMING OF UNIVERSAL PRE-K ROLLOUT IN NYC

\begin{tabular}{|c|c|c|c|c|c|}
\hline NYT44D & Goss & Shirley & \multicolumn{2}{|c|}{ daycare provider } & other \\
\hline NYT45A & Cannady & Hope & director & $\begin{array}{l}\text { Malcolm X Early } \\
\text { Childhood Center }\end{array}$ & $\begin{array}{l}\text { principal/admi } \\
\text { nistrator }\end{array}$ \\
\hline NYT45B & Butler & Andrea & teacher & $\begin{array}{l}\text { Union Settlement } \\
\text { Association }\end{array}$ & $\begin{array}{l}\text { classroom } \\
\text { teacher }\end{array}$ \\
\hline NYT45C & Tyler & GL & $\begin{array}{l}\text { political } \\
\text { director }\end{array}$ & DC 1707 & teachers union \\
\hline NYT45D & Buery & Richard & deputy mayor & NYC Mayor's Office & NYC official \\
\hline NYT45E & Nayowith & Gail & $\begin{array}{l}\text { executive } \\
\text { director }\end{array}$ & SCO Family Services & $\begin{array}{l}\text { principal/admi } \\
\text { nistrator }\end{array}$ \\
\hline NYT45F & $\begin{array}{l}\text { Contreras- } \\
\text { Collier }\end{array}$ & Maria & $\begin{array}{l}\text { executive } \\
\text { director }\end{array}$ & $\begin{array}{l}\text { Cypress Hills Childcare } \\
\text { Center }\end{array}$ & $\begin{array}{l}\text { principal/admi } \\
\text { nistrator }\end{array}$ \\
\hline NYT45G & Arrelo & Michelle & teacher & & $\begin{array}{l}\text { classroom } \\
\text { teacher }\end{array}$ \\
\hline NYT46A & Rose & Jonathan & spokesman & $\begin{array}{l}\text { Campaign for One New } \\
\text { York }\end{array}$ & $\begin{array}{l}\text { advocacy } \\
\text { organization }\end{array}$ \\
\hline NYT47A & Martino & Lisa & teacher & & $\begin{array}{l}\text { classroom } \\
\text { teacher }\end{array}$ \\
\hline NYT47B & Mahon & Janine & $\begin{array}{l}\text { director of } \\
\text { program } \\
\text { operations }\end{array}$ & $\begin{array}{l}\text { Greater Ridgewood } \\
\text { Youth Council }\end{array}$ & $\begin{array}{l}\text { principal/admi } \\
\text { nistrator }\end{array}$ \\
\hline NYT49A & Spano & Mike & \multicolumn{2}{|c|}{ mayor of Yonkers } & $\begin{array}{l}\text { other } \\
\text { government } \\
\text { official }\end{array}$ \\
\hline NYT49B & Ball & Betsey & $\begin{array}{l}\text { director of } \\
\text { legislative } \\
\text { affairs }\end{array}$ & State of New York & state official \\
\hline NYT49C & Gilmartin & Christina & \multicolumn{2}{|c|}{$\begin{array}{l}\text { spokeswoman for Yonkers Mayor Mike } \\
\text { Spano }\end{array}$} & $\begin{array}{l}\text { other } \\
\text { government } \\
\text { official }\end{array}$ \\
\hline NYT49D & Azzopardi & Richard & spokesman & State of New York & state official \\
\hline NYT49E & Cleary & Kevin & lobbyist & & other \\
\hline NYT50A & Leb & Jeff & $\begin{array}{l}\text { New York } \\
\text { State Director }\end{array}$ & Orthodox Union & other \\
\hline NYT50B & & & city officials & NYC Mayor's Office & NYC official \\
\hline NYT50C & Buery & Richard & deputy mayor & NYC Mayor's Office & NYC official \\
\hline NYT50D & Lieberman & Donna & $\begin{array}{l}\text { executive } \\
\text { director }\end{array}$ & $\begin{array}{l}\text { New York Civil } \\
\text { Liberties Union }\end{array}$ & $\begin{array}{l}\text { advocacy } \\
\text { organization }\end{array}$ \\
\hline NYT50E & Wiley & Maya & $\begin{array}{l}\text { general } \\
\text { counsel }\end{array}$ & NYC Mayor's Office & NYC official \\
\hline NYT50F & Hillman & Rebecca & $\begin{array}{l}\text { preschool } \\
\text { director }\end{array}$ & $\begin{array}{l}\text { Chabad Early Learning } \\
\text { Center }\end{array}$ & $\begin{array}{l}\text { principal/admi } \\
\text { nistrator }\end{array}$ \\
\hline NYT50G & Rolland & Cathy & $\begin{array}{l}\text { director of } \\
\text { early } \\
\text { childhood } \\
\text { education }\end{array}$ & $\begin{array}{l}\text { Union for Reform } \\
\text { Judaism }\end{array}$ & $\begin{array}{l}\text { principal/admi } \\
\text { nistrator }\end{array}$ \\
\hline NYT50H & Mannin & Francesca & principal & $\begin{array}{l}\text { Dimitrios \& Georgina } \\
\text { Kaloidis Parochial } \\
\text { School }\end{array}$ & $\begin{array}{l}\text { principal/admi } \\
\text { nistrator }\end{array}$ \\
\hline NYT51A & Diffley & Jim & economist & IHS Global Insight & other \\
\hline
\end{tabular}


NEWS FRAMING OF UNIVERSAL PRE-K ROLLOUT IN NYC

\begin{tabular}{|c|c|c|c|c|c|}
\hline \multirow{2}{*}{$\frac{\text { NYT51B }}{\text { NYT51C }}$} & \multirow{2}{*}{$\begin{array}{l}\text { Walsh } \\
\text { de Blasio }\end{array}$} & \multirow{2}{*}{$\begin{array}{l}\text { Martin } \\
\text { Bill } \\
\end{array}$} & \multicolumn{2}{|c|}{ mayor of Boston } & \multirow{2}{*}{$\begin{array}{l}\begin{array}{l}\text { other } \\
\text { government } \\
\text { official }\end{array} \\
\text { NYC official }\end{array}$} \\
\hline & & & mayor & NYC Mayor's Office & \\
\hline NYT53A & Skop & Anita & superintendent & District 15 & $\begin{array}{l}\text { principal/admi } \\
\text { nistrator }\end{array}$ \\
\hline NYT53B & Burkhaut & Brennan & mother & & parent \\
\hline NYT53C & Kushyk & Halyna & mother & & parent \\
\hline NYT54A & Stringer & Scott & comptroller & City of New York & NYC official \\
\hline NYT54B & de Blasio & Bill & mayor & NYC Mayor's Office & NYC official \\
\hline NYT55A & Jones & Shanté & $\begin{array}{l}\text { enrollment } \\
\text { specialist }\end{array}$ & $\begin{array}{l}\text { NYC Department of } \\
\text { Education }\end{array}$ & $\begin{array}{l}\text { NYC } \\
\text { education } \\
\text { official }\end{array}$ \\
\hline NYT55B & de Blasio & Bill & mayor & NYC Mayor's Office & NYC official \\
\hline NYT55C & Collins & Jessie & $\begin{array}{l}\text { executive } \\
\text { director }\end{array}$ & $\begin{array}{l}\text { Unity Neighborhood } \\
\text { Center }\end{array}$ & $\begin{array}{l}\text { principal/admi } \\
\text { nistrator }\end{array}$ \\
\hline NYT55D & Chan & Mya & $\begin{array}{l}\text { educational } \\
\text { director }\end{array}$ & Morning Star Preschool & $\begin{array}{l}\text { principal/admi } \\
\text { nistrator }\end{array}$ \\
\hline NYT55E & & & unidentified dir & 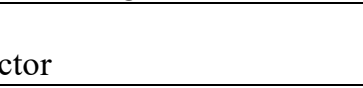 & $\begin{array}{l}\text { principal/admi } \\
\text { nistrator }\end{array}$ \\
\hline NYT55F & Stringer & Scott & comptroller & City of New York & NYC official \\
\hline NYT55G & Buery & Richard & deputy mayor & NYC Mayor's Office & NYC official \\
\hline NYT55H & Toney & Vaughan & president & $\begin{array}{l}\text { Friends of Crown } \\
\text { Height }\end{array}$ & $\begin{array}{l}\text { principal/admi } \\
\text { nistrator }\end{array}$ \\
\hline NYT55I & Blitt & Margaret & principal & & $\begin{array}{l}\text { principal/admi } \\
\text { nistrator }\end{array}$ \\
\hline NYT55J & Harrison & Anita & & $\begin{array}{l}\text { NYC Department of } \\
\text { Education }\end{array}$ & $\begin{array}{l}\text { NYC } \\
\text { education } \\
\text { official }\end{array}$ \\
\hline NYT56A & Stringer & Scott & comptroller & City of New York & NYC official \\
\hline NYT56B & de Blasio & Bill & mayor & NYC Mayor's Office & NYC official \\
\hline NYT56C & Sherrill & Kenneth & $\begin{array}{l}\text { professor } \\
\text { emeritus }\end{array}$ & Hunter College & $\begin{array}{l}\text { academic/instit } \\
\text { utionally- } \\
\text { affiliated } \\
\text { researcher }\end{array}$ \\
\hline NYT56D & Green & Mark & $\begin{array}{l}\text { former public } \\
\text { advocate }\end{array}$ & NYC Mayor's Office & NYC official \\
\hline NYT57A & Buery & Richard & deputy mayor & NYC Mayor's Office & NYC official \\
\hline NYT57B & Ruiz & Maria & mother & & parent \\
\hline NYT57C & Rivera & Bruce & father & & parent \\
\hline NYT57D & Gibson & Milda & $\begin{array}{l}\text { executive } \\
\text { director }\end{array}$ & $\begin{array}{l}\text { Rainbow After School } \\
\text { Program }\end{array}$ & $\begin{array}{l}\text { principal/admi } \\
\text { nistrator }\end{array}$ \\
\hline NYT58A & Greberyuk & Oksana & $\begin{array}{l}\text { education } \\
\text { director }\end{array}$ & $\begin{array}{l}\text { Kaleidoscope Early } \\
\text { Childhood } \\
\text { Development Center }\end{array}$ & $\begin{array}{l}\text { principal/admi } \\
\text { nistrator }\end{array}$ \\
\hline NYT58B & Urbas & Shon & father & & parent \\
\hline NYT58C & Pav & Michael & father & & parent \\
\hline NYT58D & de Blasio & Bill & mayor & NYC Mayor's Office & NYC official \\
\hline NYT58E & Benisatto & Barbara & teacher & Rego Park Day School & $\begin{array}{l}\text { classroom } \\
\text { teacher }\end{array}$ \\
\hline
\end{tabular}


NEWS FRAMING OF UNIVERSAL PRE-K ROLLOUT IN NYC

\begin{tabular}{|c|c|c|c|c|c|}
\hline NYT58F & Bruno & Jacqueline & teacher & Rego Park Day School & $\begin{array}{l}\text { classroom } \\
\text { teacher }\end{array}$ \\
\hline NYT60A & de Blasio & Bill & mayor & NYC Mayor's Office & NYC official \\
\hline NYT60B & Winchester & Ayana & mother & & parent \\
\hline NYT60C & Fariña & Carmen & $\begin{array}{l}\text { schools } \\
\text { chancellor }\end{array}$ & $\begin{array}{l}\text { NYC Department of } \\
\text { Education }\end{array}$ & $\begin{array}{l}\text { NYC } \\
\text { education } \\
\text { official }\end{array}$ \\
\hline NYT60D & Alvardo & Frank & $\begin{array}{l}\text { executive } \\
\text { director }\end{array}$ & Grant Day Care Center & $\begin{array}{l}\text { principal/admi } \\
\text { nistrator }\end{array}$ \\
\hline NYT60E & Yorke & Latisha & \multicolumn{2}{|c|}{ corrections officer } & parent \\
\hline NYT60F & Wilson & Tiffany & mother & & parent \\
\hline NYT63A & & & \multicolumn{2}{|c|}{ unidentified mother } & parent \\
\hline NYT63B & Dadey & Dick & $\begin{array}{l}\text { executive } \\
\text { director }\end{array}$ & Citizens Union & $\begin{array}{l}\text { advocacy } \\
\text { organization }\end{array}$ \\
\hline NYT63C & Lerner & Susan & $\begin{array}{l}\text { executive } \\
\text { director }\end{array}$ & $\begin{array}{l}\text { Common Cause New } \\
\text { York }\end{array}$ & $\begin{array}{l}\text { advocacy } \\
\text { organization }\end{array}$ \\
\hline NYT63D & Adams & Marti & spokeswoman & NYC Mayor's Office & NYC official \\
\hline WNYC01A & Klein & Jeff & co-leader & New York State Senate & state official \\
\hline WNYC02A & de Blasio & Bill & mayor & NYC Mayor's Office & NYC official \\
\hline WNYC02B & Cuomo & Andrew & governor & State of New York & state official \\
\hline WNYC03A & Cuomo & Andrew & governor & State of New York & state official \\
\hline WNYC03B & de Blasio & Bill & mayor & NYC Mayor's Office & NYC official \\
\hline WNYC03C & Ansari & Zakiyah & $\begin{array}{l}\text { advocacy } \\
\text { director }\end{array}$ & $\begin{array}{l}\text { Alliance for Quality } \\
\text { Education/de Blasio } \\
\text { transition team }\end{array}$ & NYC official \\
\hline WNYC03D & Sedlis & Jenny & $\begin{array}{l}\text { executive } \\
\text { director }\end{array}$ & StudentsFirstNY & $\begin{array}{l}\text { advocacy } \\
\text { organization }\end{array}$ \\
\hline WNYC04A & Silver & Sheldon & $\begin{array}{l}\text { assembly } \\
\text { speaker }\end{array}$ & $\begin{array}{l}\text { New York State } \\
\text { Assembly }\end{array}$ & state official \\
\hline WNYC04B & Klein & Jeff & co-leader & New York State Senate & state official \\
\hline WNYC04C & Iannuzzi & Richard C. & president & $\begin{array}{l}\text { New York State United } \\
\text { Teachers }\end{array}$ & teachers union \\
\hline WNYC05A & Goldsmith & David & president & $\begin{array}{l}\text { District } 13 \text { Community } \\
\text { Education Council }\end{array}$ & $\begin{array}{l}\text { other education } \\
\text { official }\end{array}$ \\
\hline WNYC06A & de Blasio & Bill & mayor & NYC Mayor's Office & NYC official \\
\hline WNYC06B & Cuomo & Andrew & governor & State of New York & state official \\
\hline WNYC06C & & & & Campaign for Children & $\begin{array}{l}\text { advocacy } \\
\text { organization }\end{array}$ \\
\hline WNYC06D & Westin & Jonathan & $\begin{array}{l}\text { executive } \\
\text { director }\end{array}$ & $\begin{array}{l}\text { New York } \\
\text { Communities for } \\
\text { Change }\end{array}$ & $\begin{array}{l}\text { advocacy } \\
\text { organization }\end{array}$ \\
\hline WNYC07A & de Blasio & Bill & mayor & NYC Mayor's Office & NYC official \\
\hline WNYC07B & Savino & Diana & senator & New York State Senate & state official \\
\hline WNYC08A & Sexton & Timothy & & & parent \\
\hline WNYC08B & $\begin{array}{l}\text { Lopez } \\
\text { Garcia }\end{array}$ & Ana Paolo & sibling & & student \\
\hline WNYC08C & Alexander & Deborah & board member & $\begin{array}{l}\text { District } 30 \text { Community } \\
\text { Education Council }\end{array}$ & $\begin{array}{l}\text { other education } \\
\text { official }\end{array}$ \\
\hline WNYC09A & Fariña & Carmen & $\begin{array}{l}\text { schools } \\
\text { chancellor }\end{array}$ & $\begin{array}{l}\text { NYC Department of } \\
\text { Education }\end{array}$ & $\begin{array}{l}\text { NYC } \\
\text { education } \\
\text { official }\end{array}$ \\
\hline
\end{tabular}


NEWS FRAMING OF UNIVERSAL PRE-K ROLLOUT IN NYC

\begin{tabular}{|c|c|c|c|c|c|}
\hline WNYC09B & Merriman & James & $\mathrm{CEO}$ & $\begin{array}{l}\text { New York City Charter } \\
\text { School Center }\end{array}$ & $\begin{array}{l}\text { advocacy } \\
\text { organization }\end{array}$ \\
\hline WNYC09C & Kittridge & Jeremiah & $\begin{array}{l}\text { executive } \\
\text { director }\end{array}$ & $\begin{array}{l}\text { Families for Excellent } \\
\text { Schools }\end{array}$ & $\begin{array}{l}\text { advocacy } \\
\text { organization }\end{array}$ \\
\hline WNYC10A & & & $\begin{array}{l}\text { unnamed } \\
\text { student }\end{array}$ & Children's Aid Society & student \\
\hline WNYC10B & Marquez & Deborah & teacher & Children's Aid Society & $\begin{array}{l}\text { classroom } \\
\text { teacher }\end{array}$ \\
\hline WNYC10C & Cappio & Moria & $\begin{array}{l}\text { vice president } \\
\text { for early } \\
\text { childhood } \\
\text { programs }\end{array}$ & Children's Aid Society & $\begin{array}{l}\text { principal/admi } \\
\text { nistrator }\end{array}$ \\
\hline WNYC11A & de Blasio & Bill & mayor & NYC Mayor's Office & NYC official \\
\hline WNYC12A & Cuomo & Andrew & governor & State of New York & state official \\
\hline WNYC12B & Dyster & Paul & mayor & Niagra Falls & $\begin{array}{l}\text { other } \\
\text { government } \\
\text { official }\end{array}$ \\
\hline WNYC12C & de Blasio & Bill & mayor & NYC Mayor's Office & NYC official \\
\hline WNYC12D & Gold & Josh & $\begin{array}{l}\text { campaign } \\
\text { manager }\end{array}$ & UPKNYC & $\begin{array}{l}\text { advocacy } \\
\text { organization }\end{array}$ \\
\hline WNYC12E & Easton & Billy & $\begin{array}{l}\text { executive } \\
\text { director }\end{array}$ & $\begin{array}{l}\text { Alliance for Quality } \\
\text { Education }\end{array}$ & $\begin{array}{l}\text { advocacy } \\
\text { organization }\end{array}$ \\
\hline WNYC13A & de Blasio & Bill & mayor & NYC Mayor's Office & NYC official \\
\hline WNYC13B & Noguera & Pedro & professor & New York University & $\begin{array}{l}\text { academic/instit } \\
\text { utionally- } \\
\text { affiliated } \\
\text { researcher }\end{array}$ \\
\hline WNYC13C & Cuomo & Andrew & governor & State of New York & state official \\
\hline WNYC13D & Silver & Sheldon & $\begin{array}{l}\text { assembly } \\
\text { speaker }\end{array}$ & $\begin{array}{l}\text { New York State } \\
\text { Assembly }\end{array}$ & state official \\
\hline WNYC14A & Pappas & Sophia & $\begin{array}{l}\text { executive } \\
\text { director of } \\
\text { Early } \\
\text { Childhood } \\
\text { Education }\end{array}$ & $\begin{array}{l}\text { NYC Department of } \\
\text { Education }\end{array}$ & $\begin{array}{l}\text { NYC } \\
\text { education } \\
\text { official }\end{array}$ \\
\hline WNYC15A & Sternback & Jenna & mother & & parent \\
\hline WNYC15B & Piper & Jerry & $\begin{array}{l}\text { parent } \\
\text { coordinator }\end{array}$ & PS 261 & other \\
\hline WNYC15C & Whittaker & Anona & mother & & parent \\
\hline WNYC16A & Silver & Sheldon & $\begin{array}{l}\text { assembly } \\
\text { speaker }\end{array}$ & $\begin{array}{l}\text { New York State } \\
\text { Assembly }\end{array}$ & state official \\
\hline WNYC16B & Cuomo & Andrew & governor & State of New York & state official \\
\hline WNYC17A & de Blasio & Bill & mayor & NYC Mayor's Office & NYC official \\
\hline WNYC18A & Pappas & Sophia & $\begin{array}{l}\text { executive } \\
\text { director of } \\
\text { Early } \\
\text { Childhood } \\
\text { Education }\end{array}$ & $\begin{array}{l}\text { NYC Department of } \\
\text { Education }\end{array}$ & $\begin{array}{l}\text { NYC } \\
\text { education } \\
\text { official }\end{array}$ \\
\hline WNYC18B & Wilson & Tesa & co-president & $\begin{array}{l}\text { District } 14 \text { Community } \\
\text { Education Council }\end{array}$ & $\begin{array}{l}\text { other educatior } \\
\text { official }\end{array}$ \\
\hline WNYC18C & Antonelli & Steven & $\begin{array}{l}\text { administrative } \\
\text { director }\end{array}$ & Bank Street Head Start & $\begin{array}{l}\text { principal/admi } \\
\text { nistrator }\end{array}$ \\
\hline
\end{tabular}


NEWS FRAMING OF UNIVERSAL PRE-K ROLLOUT IN NYC

\begin{tabular}{|c|c|c|c|c|c|}
\hline WNYC19A & de Blasio & Bill & mayor & NYC Mayor's Office & NYC official \\
\hline WNYC20A & Norvell & Wiley & spokesman & NYC Mayor's Office & NYC official \\
\hline WNYC20B & & & & Campaign for Children & $\begin{array}{l}\text { advocacy } \\
\text { organization }\end{array}$ \\
\hline WNYC20C & Kittridge & Jeremiah & $\begin{array}{l}\text { executive } \\
\text { director }\end{array}$ & $\begin{array}{l}\text { Families for Excellent } \\
\text { Schools }\end{array}$ & $\begin{array}{l}\text { advocacy } \\
\text { organization }\end{array}$ \\
\hline WNYC20D & Easton & Billy & $\begin{array}{l}\text { executive } \\
\text { director }\end{array}$ & $\begin{array}{l}\text { Alliance for Quality } \\
\text { Education }\end{array}$ & $\begin{array}{l}\text { advocacy } \\
\text { organization }\end{array}$ \\
\hline WNYC21A & de Blasio & Bill & mayor & NYC Mayor's Office & NYC official \\
\hline WNYC21B & Fariña & Carmen & $\begin{array}{l}\text { schools } \\
\text { chancellor }\end{array}$ & $\begin{array}{l}\text { NYC Department of } \\
\text { Education }\end{array}$ & $\begin{array}{l}\text { NYC } \\
\text { education } \\
\text { official }\end{array}$ \\
\hline WNYC21C & Carmignani & Isaac & co-president & & $\begin{array}{l}\text { other educatior } \\
\text { official }\end{array}$ \\
\hline WNYC22A & Nocenti & David & $\begin{array}{l}\text { executive } \\
\text { director }\end{array}$ & $\begin{array}{l}\text { Union Settlement } \\
\text { Association }\end{array}$ & $\begin{array}{l}\text { principal/admi } \\
\text { nistrator }\end{array}$ \\
\hline WNYC23A & Pappas & Sophia & $\begin{array}{l}\text { executive } \\
\text { director of } \\
\text { Early } \\
\text { Childhood } \\
\text { Education }\end{array}$ & $\begin{array}{l}\text { NYC Department of } \\
\text { Education }\end{array}$ & $\begin{array}{l}\text { NYC } \\
\text { education } \\
\text { official }\end{array}$ \\
\hline WNYC25A & Buery & Richard & deputy mayor & NYC Mayor's Office & NYC official \\
\hline WNYC25B & Wallack & Josh & $\begin{array}{l}\text { chief strategy } \\
\text { officer }\end{array}$ & $\begin{array}{l}\text { NYC Department of } \\
\text { Education }\end{array}$ & $\begin{array}{l}\text { NYC } \\
\text { education } \\
\text { official }\end{array}$ \\
\hline WNYC25C & Gallagher & Regina & $\begin{array}{l}\text { head of early } \\
\text { childhood } \\
\text { education }\end{array}$ & $\begin{array}{l}\text { Goddard Riverside } \\
\text { Community Center }\end{array}$ & $\begin{array}{l}\text { principal/admi } \\
\text { nistrator }\end{array}$ \\
\hline WNYC26A & Fariña & Carmen & $\begin{array}{l}\text { schools } \\
\text { chancellor }\end{array}$ & $\begin{array}{l}\text { NYC Department of } \\
\text { Education }\end{array}$ & $\begin{array}{l}\text { NYC } \\
\text { education } \\
\text { official }\end{array}$ \\
\hline WNYC27A & Pappas & Sophia & $\begin{array}{l}\text { executive } \\
\text { director of } \\
\text { Early } \\
\text { Childhood } \\
\text { Education } \\
\end{array}$ & $\begin{array}{l}\text { NYC Department of } \\
\text { Education }\end{array}$ & $\begin{array}{l}\text { NYC } \\
\text { education } \\
\text { official }\end{array}$ \\
\hline WNYC28A & Cleary & Sherry & $\begin{array}{l}\text { executive } \\
\text { director }\end{array}$ & $\begin{array}{l}\text { CUNY/New York City } \\
\text { Early Childhood } \\
\text { Professional } \\
\text { Development Institute }\end{array}$ & $\begin{array}{l}\text { college } \\
\text { administrator }\end{array}$ \\
\hline WNYC29A & Buery & Richard & deputy mayor & NYC Mayor's Office & NYC official \\
\hline WNYC30A & Gallagher & Regina & $\begin{array}{l}\text { head of early } \\
\text { childhood } \\
\text { education }\end{array}$ & $\begin{array}{l}\text { Goddard Riverside } \\
\text { Community Center }\end{array}$ & $\begin{array}{l}\text { principal/admi } \\
\text { nistrator }\end{array}$ \\
\hline WNYC30B & & & $\begin{array}{l}\text { unnamed } \\
\text { teacher }\end{array}$ & $\begin{array}{l}\text { Goddard Riverside } \\
\text { Community Center }\end{array}$ & $\begin{array}{l}\text { classroom } \\
\text { teacher }\end{array}$ \\
\hline WNYC30C & Rider & Terry & principal & PSIS 276 & $\begin{array}{l}\text { principal/admi } \\
\text { nistrator }\end{array}$ \\
\hline WNYC31A & de Blasio & Bill & mayor & NYC Mayor's Office & NYC official \\
\hline WNYC31B & Cappio & Moria & $\begin{array}{l}\text { vice president } \\
\text { for early }\end{array}$ & Children's Aid Society & $\begin{array}{l}\text { principal/admi } \\
\text { nistrator }\end{array}$ \\
\hline
\end{tabular}


NEWS FRAMING OF UNIVERSAL PRE-K ROLLOUT IN NYC

\begin{tabular}{|c|c|c|c|c|c|}
\hline & & & $\begin{array}{l}\text { childhood } \\
\text { programs }\end{array}$ & & \\
\hline WNYC31C & Barclift & Fela & founder & Little Sun People & $\begin{array}{l}\text { principal/admi } \\
\text { nistrator }\end{array}$ \\
\hline WNYC33A & de Blasio & Bill & mayor & NYC Mayor's Office & NYC official \\
\hline WNYC35A & Cleary & Sherry & $\begin{array}{l}\text { executive } \\
\text { director }\end{array}$ & $\begin{array}{l}\text { CUNY/New York City } \\
\text { Early Childhood } \\
\text { Professional } \\
\text { Development Institute }\end{array}$ & $\begin{array}{l}\text { college } \\
\text { administrator }\end{array}$ \\
\hline WNYC35B & Pappas & Sophia & $\begin{array}{l}\text { executive } \\
\text { director of } \\
\text { Early } \\
\text { Childhood } \\
\text { Education }\end{array}$ & $\begin{array}{l}\text { NYC Department of } \\
\text { Education }\end{array}$ & $\begin{array}{l}\text { NYC } \\
\text { education } \\
\text { official }\end{array}$ \\
\hline WNYC36A & Posporelis & Dawn & manager & $\begin{array}{l}\text { Precious Moments } \\
\text { Nursery School }\end{array}$ & $\begin{array}{l}\text { principal/admi } \\
\text { nistrator }\end{array}$ \\
\hline WNYC36B & Tompkins & Ron & recruiter & & $\begin{array}{l}\text { other educatior } \\
\text { official }\end{array}$ \\
\hline WNYC36C & Sperling & Stacey & yoga instructor & CUNY & $\begin{array}{l}\text { classroom } \\
\text { teacher }\end{array}$ \\
\hline WNYC37A & Endzweig & Luzer & \multicolumn{2}{|l|}{ United Supply } & other \\
\hline WNYC37B & Cappio & Moria & $\begin{array}{l}\text { vice president } \\
\text { for early } \\
\text { childhood } \\
\text { programs }\end{array}$ & Children's Aid Society & $\begin{array}{l}\text { principal/admi } \\
\text { nistrator }\end{array}$ \\
\hline WNYC37C & Ross & David & $\begin{array}{l}\text { purchasing } \\
\text { director }\end{array}$ & $\begin{array}{l}\text { NYC Department of } \\
\text { Education }\end{array}$ & $\begin{array}{l}\text { NYC } \\
\text { education } \\
\text { official } \\
\end{array}$ \\
\hline WNYC37D & Brugman & Bill & \multicolumn{2}{|l|}{ furniture maker } & other \\
\hline WNYC38A & de Blasio & Bill & mayor & NYC Mayor's Office & NYC official \\
\hline WNYC38B & Fariña & Carmen & $\begin{array}{l}\text { schools } \\
\text { chancellor }\end{array}$ & $\begin{array}{l}\text { NYC Department of } \\
\text { Education }\end{array}$ & $\begin{array}{l}\text { NYC } \\
\text { education } \\
\text { official }\end{array}$ \\
\hline WNYC39A & Warley & Tahese & teacher & CUNY & $\begin{array}{l}\text { classroom } \\
\text { teacher }\end{array}$ \\
\hline WNYC39B & Vanderbilt & Kim & program liason & $\begin{array}{l}\text { CUNY/Lehman } \\
\text { College }\end{array}$ & $\begin{array}{l}\text { higher } \\
\text { education staff }\end{array}$ \\
\hline WNYC39C & Miree & Ruby & teacher & & $\begin{array}{l}\text { classroom } \\
\text { teacher }\end{array}$ \\
\hline WNYC39D & Haynes & Aneesha & teacher & & $\begin{array}{l}\text { classroom } \\
\text { teacher }\end{array}$ \\
\hline WNYC39E & Haynes & Ashley & teacher & & $\begin{array}{l}\text { classroom } \\
\text { teacher }\end{array}$ \\
\hline WNYC40A & de Blasio & Bill & mayor & NYC Mayor's Office & NYC official \\
\hline WNYC41A & Zhuo & George & $\begin{array}{l}\text { outreach } \\
\text { worker }\end{array}$ & $\begin{array}{l}\text { NYC Department of } \\
\text { Education }\end{array}$ & $\begin{array}{l}\text { NYC } \\
\text { education } \\
\text { official }\end{array}$ \\
\hline WNYC41B & $\mathrm{Li}$ & Yan Fei & parent & & parent \\
\hline WNYC41C & Hay & Jeremy & & $\begin{array}{l}\text { NYC Department of } \\
\text { Education }\end{array}$ & $\begin{array}{l}\text { NYC } \\
\text { education } \\
\text { official } \\
\end{array}$ \\
\hline
\end{tabular}


NEWS FRAMING OF UNIVERSAL PRE-K ROLLOUT IN NYC

\begin{tabular}{|c|c|c|c|c|c|}
\hline WNYC41D & Shareef & Shavana & & $\begin{array}{l}\text { NYC Department of } \\
\text { Education }\end{array}$ & $\begin{array}{l}\text { NYC } \\
\text { education } \\
\text { official }\end{array}$ \\
\hline WNYC41E & Daniel & Marietta & & $\begin{array}{l}\text { NYC Department of } \\
\text { Education }\end{array}$ & $\begin{array}{l}\text { NYC } \\
\text { education } \\
\text { official }\end{array}$ \\
\hline WNYC42A & Stringer & Scott & comptroller & City of New York & NYC official \\
\hline WNYC42B & de Blasio & Bill & mayor & NYC Mayor's Office & NYC official \\
\hline WNYC42C & Buery & Richard & deputy mayor & NYC Mayor's Office & NYC official \\
\hline WNYC43A & de Blasio & Bill & mayor & NYC Mayor's Office & NYC official \\
\hline WNYC43B & Carrion & Gladys & commissioner & $\begin{array}{l}\text { Administration for } \\
\text { Children's Services }\end{array}$ & NYC official \\
\hline WNYC43C & Fariña & Carmen & $\begin{array}{l}\text { schools } \\
\text { chancellor }\end{array}$ & $\begin{array}{l}\text { NYC Department of } \\
\text { Education }\end{array}$ & $\begin{array}{l}\text { NYC } \\
\text { education } \\
\text { official }\end{array}$ \\
\hline WNYC43D & Buery & Richard & deputy mayor & NYC Mayor's Office & NYC official \\
\hline WNYC44A & Peters & Glenn & teacher & & $\begin{array}{l}\text { classroom } \\
\text { teacher }\end{array}$ \\
\hline WNYC44B & Cleary & Sherry & $\begin{array}{l}\text { executive } \\
\text { director }\end{array}$ & $\begin{array}{l}\text { CUNY/New York City } \\
\text { Early Childhood } \\
\text { Professional } \\
\text { Development Institute }\end{array}$ & $\begin{array}{l}\text { college } \\
\text { administrator }\end{array}$ \\
\hline WNYC44C & Barbarin & Oscar & $\begin{array}{l}\text { professor of } \\
\text { psychology }\end{array}$ & Tulane University & $\begin{array}{l}\text { academic/instit } \\
\text { utionally- } \\
\text { affiliated } \\
\text { researcher }\end{array}$ \\
\hline WNYC44D & & & \multicolumn{2}{|c|}{ unnamed student } & student \\
\hline WNYC44E & Antonelli & Steven & $\begin{array}{l}\text { administrative } \\
\text { director }\end{array}$ & Bank Street Head Start & $\begin{array}{l}\text { principal/admi } \\
\text { nistrator }\end{array}$ \\
\hline WNYC45A & Buery & Richard & deputy mayor & NYC Mayor's Office & NYC official \\
\hline WNYC46A & de Blasio & Bill & mayor & NYC Mayor's Office & NYC official \\
\hline WNYC47A & de Blasio & Bill & mayor & NYC Mayor's Office & NYC official \\
\hline WNYC47B & Buery & Richard & deputy mayor & NYC Mayor's Office & NYC official \\
\hline WNYC47C & Swiney & Reginald & father & & parent \\
\hline WNYC47D & Baker & Kimberly & mother & & parent \\
\hline WNYC47E & Fink & Kathleen & principal & Little Nest Pre-K & $\begin{array}{l}\text { principal/admi } \\
\text { nistrator }\end{array}$ \\
\hline WNYC48A & Dabon & Mia & student & Fort George Preschool & student \\
\hline WNYC48B & de Blasio & Bill & mayor & NYC Mayor's Office & NYC official \\
\hline WNYC48C & McCray & Chirlane & First Lady & NYC Mayor's Office & NYC official \\
\hline WNYC48D & Fariña & Carmen & $\begin{array}{l}\text { schools } \\
\text { chancellor }\end{array}$ & $\begin{array}{l}\text { NYC Department of } \\
\text { Education }\end{array}$ & $\begin{array}{l}\text { NYC } \\
\text { education } \\
\text { official }\end{array}$ \\
\hline WNYC48E & Alexander & Wendy & mother & & parent \\
\hline WNYC48F & Chavez & Jaynaliz & student & & student \\
\hline WNYC48G & Santos & Eva & mother & & parent \\
\hline WNYC48H & & & parent & & parent \\
\hline WNYC49A & de Blasio & Bill & mayor & NYC Mayor's Office & NYC official \\
\hline WNYC49B & Fariña & Carmen & $\begin{array}{l}\text { schools } \\
\text { chancellor }\end{array}$ & $\begin{array}{l}\text { NYC Department of } \\
\text { Education }\end{array}$ & $\begin{array}{l}\text { NYC } \\
\text { education } \\
\text { official }\end{array}$ \\
\hline
\end{tabular}


NEWS FRAMING OF UNIVERSAL PRE-K ROLLOUT IN NYC

\begin{tabular}{|c|c|c|c|c|c|}
\hline WNYC49C & Buery & Richard & deputy mayor & NYC Mayor's Office & NYC official \\
\hline WNYC50A & Toney & Vaugn & director & $\begin{array}{l}\text { The Friends of Crown } \\
\text { Height }\end{array}$ & $\begin{array}{l}\text { principal/admi } \\
\text { nistrator }\end{array}$ \\
\hline WNYC50B & Ho & Haney & vice president & $\begin{array}{l}\text { Brooklyn Chinese } \\
\text { American Association }\end{array}$ & $\begin{array}{l}\text { principal/admi } \\
\text { nistrator }\end{array}$ \\
\hline WNYC51A & Miree & Ruby & teacher & Fort George Preschool & $\begin{array}{l}\text { classroom } \\
\text { teacher }\end{array}$ \\
\hline WNYC51B & & & \multicolumn{2}{|c|}{ unnamed student } & student \\
\hline WNYC51C & Abrayo & Jennifer & teacher & & $\begin{array}{l}\text { classroom } \\
\text { teacher }\end{array}$ \\
\hline WNYC51D & & & \multicolumn{2}{|c|}{ unnamed student } & student \\
\hline WNYC51E & & & \multicolumn{2}{|c|}{ unnamed student } & student \\
\hline WNYC51F & & & husband & & other \\
\hline WNYC51G & & & son & & other \\
\hline WNYC51H & Warley & Tahese & teacher & Fort George Preschool & $\begin{array}{l}\text { classroom } \\
\text { teacher }\end{array}$ \\
\hline WNYC51I & & & \multicolumn{2}{|l|}{ unnamed father } & parent \\
\hline WNYC51J & & & parent & & parent \\
\hline WNYC52A & Cappio & Moria & $\begin{array}{l}\text { vice president } \\
\text { for early } \\
\text { childhood } \\
\text { programs }\end{array}$ & Children's Aid Society & $\begin{array}{l}\text { principal/admi } \\
\text { nistrator }\end{array}$ \\
\hline WNYC52B & Wallack & Josh & $\begin{array}{l}\text { chief strategy } \\
\text { officer }\end{array}$ & $\begin{array}{l}\text { NYC Department of } \\
\text { Education }\end{array}$ & $\begin{array}{l}\text { NYC } \\
\text { education } \\
\text { official }\end{array}$ \\
\hline WNYC53A & Mirsky & Alexandra & & $\begin{array}{l}\text { NYC Department of } \\
\text { Education }\end{array}$ & $\begin{array}{l}\text { NYC } \\
\text { education } \\
\text { official }\end{array}$ \\
\hline WNYC53B & & & $\begin{array}{l}\text { unnamed } \\
\text { spokesman }\end{array}$ & $\begin{array}{l}\text { NYC Department of } \\
\text { Education }\end{array}$ & $\begin{array}{l}\text { NYC } \\
\text { education } \\
\text { official }\end{array}$ \\
\hline WNYC53C & Fromberg & Rick & $\begin{array}{l}\text { senior advisor } \\
\text { on pre-K }\end{array}$ & NYC Mayor's Office & NYC official \\
\hline WNYC54A & Buery & Richard & deputy mayor & NYC Mayor's Office & NYC official \\
\hline WNYC54B & Morris & Pamela & professor & New York University & $\begin{array}{l}\text { academic/instit } \\
\text { utionally- } \\
\text { affiliated } \\
\text { researcher }\end{array}$ \\
\hline WNYC54C & Yoshikawa & Hirokazu & expert & New York University & $\begin{array}{l}\text { academic/instit } \\
\text { utionally- } \\
\text { affiliated } \\
\text { researcher }\end{array}$ \\
\hline WNYC55A & Buery & Richard & deputy mayor & NYC Mayor's Office & NYC official \\
\hline WNYC55B & Gensler & Jonah & director & $\begin{array}{l}\text { Sunnyside Community } \\
\text { Services }\end{array}$ & $\begin{array}{l}\text { principal/admi } \\
\text { nistrator }\end{array}$ \\
\hline WNYC55C & Frede & Ellen & & $\begin{array}{l}\text { New Jersey Education } \\
\text { Department }\end{array}$ & $\begin{array}{l}\text { other education } \\
\text { official }\end{array}$ \\
\hline WNYC55D & Jockers & Ken & director & Hudson Guild & $\begin{array}{l}\text { principal/admi } \\
\text { nistrator }\end{array}$ \\
\hline WNYC55E & & & \multicolumn{2}{|c|}{ unnamed student } & student \\
\hline WNYC55F & Fink & Kathleen & principal & Little Nest Pre-K & $\begin{array}{l}\text { principal/admi } \\
\text { nistrator }\end{array}$ \\
\hline
\end{tabular}


NEWS FRAMING OF UNIVERSAL PRE-K ROLLOUT IN NYC

\begin{tabular}{|c|c|c|c|c|c|}
\hline WNYC56A & de Blasio & Bill & mayor & NYC Mayor's Office & NYC official \\
\hline WNYC56B & Cappio & Moria & $\begin{array}{l}\text { vice president } \\
\text { for early } \\
\text { childhood } \\
\text { programs }\end{array}$ & Children's Aid Society & $\begin{array}{l}\text { principal/admi } \\
\text { nistrator }\end{array}$ \\
\hline WNYC57A & Kaye & Devora & spokesman & $\begin{array}{l}\text { NYC Department of } \\
\text { Education }\end{array}$ & $\begin{array}{l}\text { NYC } \\
\text { education } \\
\text { official }\end{array}$ \\
\hline WNYC57B & Dubitsky & Rose Silva & principal & PS 24 & $\begin{array}{l}\text { principal/admi } \\
\text { nistrator }\end{array}$ \\
\hline WNYC57C & Rosenberg & $\mathrm{Liz}$ & mother & & parent \\
\hline WNYC58A & King & Paul & $\begin{array}{l}\text { director of the } \\
\text { arts }\end{array}$ & $\begin{array}{l}\text { NYC Department of } \\
\text { Education }\end{array}$ & $\begin{array}{l}\text { NYC } \\
\text { education } \\
\text { official }\end{array}$ \\
\hline WNYC58B & & & $\begin{array}{l}\text { unnamed } \\
\text { student }\end{array}$ & $\begin{array}{l}\text { Stepping Stone Day } \\
\text { School }\end{array}$ & student \\
\hline WNYC58C & Gotlieb & Ester & teacher & $\begin{array}{l}\text { Stepping Stone Day } \\
\text { School }\end{array}$ & $\begin{array}{l}\text { classroom } \\
\text { teacher }\end{array}$ \\
\hline WNYC58D & Guy & Kathy & instructor & $\begin{array}{l}\text { NYC Department of } \\
\text { Education }\end{array}$ & $\begin{array}{l}\text { NYC } \\
\text { education } \\
\text { official } \\
\end{array}$ \\
\hline WNYC58E & Blatchley & Betsy & instructor & $\begin{array}{l}\text { NYC Department of } \\
\text { Education }\end{array}$ & $\begin{array}{l}\text { NYC } \\
\text { education } \\
\text { official }\end{array}$ \\
\hline WNYC58F & Pyle & Stuart & instructor & $\begin{array}{l}\text { NYC Department of } \\
\text { Education }\end{array}$ & $\begin{array}{l}\text { NYC } \\
\text { education } \\
\text { official } \\
\end{array}$ \\
\hline WNYC59A & Norvell & Wiley & spokesman & NYC Mayor's Office & NYC official \\
\hline WNYC59B & Warley & Tahese & teacher & Fort George Preschool & $\begin{array}{l}\text { classroom } \\
\text { teacher }\end{array}$ \\
\hline WNYC59C & de Blasio & Bill & mayor & NYC Mayor's Office & NYC official \\
\hline WNYC59D & Buery & Richard & deputy mayor & NYC Mayor's Office & NYC official \\
\hline WNYC60A & Obama & Barack & president & United States & $\begin{array}{l}\text { other } \\
\text { government } \\
\text { official }\end{array}$ \\
\hline WNYC60B & Cuomo & Andrew & governor & State of New York & state official \\
\hline WNYC60C & Buery & Richard & deputy mayor & NYC Mayor's Office & NYC official \\
\hline WNYC61A & Pappas & Sophia & $\begin{array}{l}\text { executive } \\
\text { director of } \\
\text { Early } \\
\text { Childhood } \\
\text { Education }\end{array}$ & $\begin{array}{l}\text { NYC Department of } \\
\text { Education }\end{array}$ & $\begin{array}{l}\text { NYC } \\
\text { education } \\
\text { official }\end{array}$ \\
\hline WNYC61B & Yoshikawa & Hirokazu & $\begin{array}{l}\text { education } \\
\text { professor }\end{array}$ & New York University & $\begin{array}{l}\text { academic/instit } \\
\text { utionally- } \\
\text { affiliated } \\
\text { researcher }\end{array}$ \\
\hline WNYC61C & Warley & Tahese & teacher & Fort George Preschool & $\begin{array}{l}\text { classroom } \\
\text { teacher }\end{array}$ \\
\hline WNYC62A & Cleary & Sherry & $\begin{array}{l}\text { executive } \\
\text { director }\end{array}$ & $\begin{array}{l}\text { CUNY/New York City } \\
\text { Early Childhood } \\
\text { Professional } \\
\text { Development Institute }\end{array}$ & $\begin{array}{l}\text { college } \\
\text { administrator }\end{array}$ \\
\hline
\end{tabular}


NEWS FRAMING OF UNIVERSAL PRE-K ROLLOUT IN NYC

\begin{tabular}{|l|l|l|l|l|l|}
\hline WNYC62B & $\begin{array}{l}\text { Strum- } \\
\text { Drown }\end{array}$ & Barbara & principal & & $\begin{array}{l}\text { principal/admi } \\
\text { nistrator }\end{array}$ \\
\hline
\end{tabular}


NEWS FRAMING OF UNIVERSAL PRE-K ROLLOUT IN NYC

\section{Appendix H - Frames by Media Type}

\section{Chalkbeat}

\begin{tabular}{|c|c|c|c|c|c|c|}
\hline Identifier & Responsibility & $\begin{array}{l}\text { Human } \\
\text { interest }\end{array}$ & Morality & Conflict & $\begin{array}{l}\text { Economic } \\
\text { consequence }\end{array}$ & $\begin{array}{l}\text { Failing } \\
\text { schools? }\end{array}$ \\
\hline CHALK01 & 0 & 0 & 0 & 0 & 1 & 0 \\
\hline CHALK02 & 0 & 0 & 0 & 1 & 0 & 0 \\
\hline CHALK03 & 0 & 0 & 0 & 1 & 0 & 0 \\
\hline CHALK04 & 0 & 0 & 0 & 0 & 0 & 0 \\
\hline CHALK05 & 0 & 0 & 0 & 1 & 0 & 0 \\
\hline CHALK06 & 0 & 0 & 0 & 1 & 0 & 0 \\
\hline CHALK07 & 0 & 0 & 1 & 1 & 1 & 0 \\
\hline CHALK08 & 0 & 0 & 0 & 0 & 0 & 0 \\
\hline CHALK09 & 0 & 0 & 0 & 0 & 0 & 1 \\
\hline CHALK10 & 1 & 0 & 1 & 0 & 0 & 0 \\
\hline CHALK11 & 0 & 0 & 1 & 0 & 1 & 0 \\
\hline CHALK12 & 0 & 0 & 0 & 1 & 0 & 0 \\
\hline CHALK13 & 0 & 0 & 0 & 1 & 0 & 0 \\
\hline CHALK14 & 0 & 0 & 0 & 1 & 0 & 0 \\
\hline CHALK15 & 0 & 0 & 0 & 1 & 0 & 0 \\
\hline CHALK16 & 0 & 0 & 0 & 1 & 0 & 0 \\
\hline CHALK17 & 0 & 0 & 1 & 1 & 0 & 0 \\
\hline CHALK18 & 0 & 0 & 0 & 0 & 0 & 0 \\
\hline CHALK19 & 0 & 0 & 0 & 1 & 0 & 0 \\
\hline CHALK20 & 0 & 0 & 0 & 0 & 0 & 0 \\
\hline CHALK21 & 0 & 0 & 0 & 0 & 0 & 0 \\
\hline CHALK22 & 0 & 0 & 0 & 0 & 0 & 0 \\
\hline CHALK23 & 0 & 0 & 0 & 1 & 0 & 0 \\
\hline CHALK24 & 0 & 1 & 0 & 1 & 0 & 0 \\
\hline CHALK25 & 0 & 1 & 0 & 0 & 0 & 0 \\
\hline CHALK26 & 0 & 1 & 0 & 1 & 0 & 0 \\
\hline CHALK27 & 0 & 0 & 0 & 1 & 0 & 0 \\
\hline CHALK28 & 0 & 0 & 0 & 0 & 0 & 1 \\
\hline CHALK29 & 0 & 1 & 0 & 0 & 0 & 0 \\
\hline CHALK31 & 0 & 0 & 0 & 0 & 0 & 0 \\
\hline CHALK32 & 0 & 0 & 0 & 0 & 1 & 0 \\
\hline CHALK33 & 0 & 0 & 0 & 0 & 1 & 0 \\
\hline CHALK34 & 0 & 0 & 0 & 0 & 0 & 0 \\
\hline CHALK35 & 0 & 0 & 0 & 0 & 0 & 0 \\
\hline
\end{tabular}


NEWS FRAMING OF UNIVERSAL PRE-K ROLLOUT IN NYC

\begin{tabular}{|c|c|c|c|c|c|c|}
\hline CHALK36 & 0 & 0 & 0 & 0 & 0 & 0 \\
\hline CHALK37 & 0 & 0 & 0 & 0 & 0 & 0 \\
\hline CHALK38 & 0 & 0 & 0 & 1 & 0 & 0 \\
\hline CHALK39 & 0 & 0 & 0 & 1 & 1 & 0 \\
\hline CHALK40 & 0 & 0 & 0 & 0 & 0 & 0 \\
\hline CHALK41 & 0 & 1 & 0 & 0 & 0 & 0 \\
\hline CHALK42 & 0 & 0 & 0 & 1 & 0 & 0 \\
\hline CHALK43 & 0 & 0 & 0 & 1 & 0 & 0 \\
\hline CHALK44 & 0 & 1 & 0 & 0 & 0 & 0 \\
\hline CHALK45 & 0 & 0 & 0 & 0 & 0 & 0 \\
\hline CHALK46 & 0 & 1 & 0 & 0 & 0 & 0 \\
\hline CHALK47 & 0 & 1 & 0 & 1 & 0 & 0 \\
\hline CHALK48 & 0 & 0 & 0 & 0 & 0 & 0 \\
\hline CHALK49 & 0 & 0 & 0 & 0 & 0 & 0 \\
\hline CHALK50 & 0 & 1 & 0 & 0 & 0 & 0 \\
\hline CHALK52 & 1 & 0 & 0 & 0 & 0 & 0 \\
\hline CHALK53 & 0 & 0 & 0 & 0 & 0 & 0 \\
\hline CHALK54 & 0 & 0 & 0 & 1 & 0 & 0 \\
\hline CHALK55 & 0 & 1 & 0 & 0 & 0 & 0 \\
\hline CHALK56 & 1 & 0 & 0 & 0 & 0 & 0 \\
\hline CHALK57 & 0 & 0 & 0 & 0 & 0 & 0 \\
\hline CHALK58 & 0 & 1 & 0 & 0 & 0 & 0 \\
\hline CHALK59 & 1 & 1 & 0 & 0 & 0 & 0 \\
\hline CHALK60 & 0 & 0 & 0 & 0 & 0 & 0 \\
\hline CHALK61 & 0 & 0 & 0 & 1 & 0 & 0 \\
\hline CHALK62 & 1 & 0 & 0 & 1 & 0 & 0 \\
\hline CHALK63 & 1 & 0 & 0 & 0 & 0 & 0 \\
\hline CHALK64 & 0 & 1 & 0 & 0 & 0 & 0 \\
\hline CHALK66 & 1 & 0 & 0 & 1 & 0 & 1 \\
\hline CHALK67 & 0 & 0 & 1 & 1 & 0 & 0 \\
\hline CHALK68 & 0 & 0 & 0 & 0 & 0 & 0 \\
\hline CHALK69 & 1 & 0 & 0 & 0 & 0 & 0 \\
\hline CHALK70 & 0 & 0 & 0 & 0 & 0 & 0 \\
\hline Total & 8 & 13 & 5 & 26 & 6 & 3 \\
\hline Percent & 11.94 & 19.40 & 7.46 & 38.80 & 8.95 & 4.47 \\
\hline
\end{tabular}


NEWS FRAMING OF UNIVERSAL PRE-K ROLLOUT IN NYC

The New York Times

\begin{tabular}{|c|c|c|c|c|c|c|}
\hline Identifier & Responsibility & $\begin{array}{l}\text { Human } \\
\text { interest }\end{array}$ & Morality & Conflict & $\begin{array}{l}\text { Economic } \\
\text { consequence }\end{array}$ & $\begin{array}{l}\text { Failing } \\
\text { schools? }\end{array}$ \\
\hline NYT02 & 0 & 1 & 1 & 1 & 0 & 0 \\
\hline NYT03 & 0 & 0 & 1 & 0 & 1 & 0 \\
\hline NYT04 & 0 & 0 & 0 & 1 & 0 & 0 \\
\hline NYT05 & 0 & 0 & 0 & 1 & 0 & 0 \\
\hline NYT06 & 0 & 0 & 0 & 1 & 0 & 0 \\
\hline NYT08 & 0 & 0 & 0 & 1 & 0 & 0 \\
\hline NYT09 & 0 & 0 & 0 & 1 & 1 & 0 \\
\hline NYT11 & 0 & 0 & 0 & 0 & 0 & 0 \\
\hline NYT12 & 0 & 1 & 0 & 0 & 0 & 0 \\
\hline NYT13 & 0 & 0 & 0 & 1 & 0 & 0 \\
\hline NYT14 & 0 & 0 & 0 & 1 & 0 & 0 \\
\hline NYT15 & 0 & 0 & 0 & 0 & 0 & 0 \\
\hline NYT16 & 0 & 0 & 0 & 1 & 1 & 0 \\
\hline NYT17 & 0 & 1 & 0 & 0 & 0 & 0 \\
\hline NYT18 & 0 & 0 & 0 & 1 & 0 & 0 \\
\hline NYT20 & 0 & 0 & 0 & 0 & 1 & 0 \\
\hline NYT21 & 0 & 0 & 0 & 1 & 0 & 0 \\
\hline NYT22 & 0 & 0 & 0 & 1 & 1 & 0 \\
\hline NYT24 & 0 & 0 & 0 & 1 & 0 & 0 \\
\hline NYT25 & 0 & 0 & 0 & 1 & 0 & 0 \\
\hline NYT26 & 0 & 0 & 0 & 1 & 0 & 0 \\
\hline NYT27 & 0 & 0 & 0 & 0 & 0 & 0 \\
\hline NYT30 & 0 & 1 & 0 & 0 & 0 & 0 \\
\hline NYT31 & 0 & 1 & 0 & 0 & 0 & 0 \\
\hline NYT32 & 0 & 0 & 0 & 1 & 0 & 0 \\
\hline NYT33 & 0 & 0 & 0 & 1 & 1 & 0 \\
\hline NYT34 & 0 & 0 & 0 & 0 & 1 & 0 \\
\hline NYT35 & 1 & 0 & 0 & 1 & 0 & 0 \\
\hline NYT36 & 1 & 0 & 0 & 0 & 0 & 0 \\
\hline NYT38 & 0 & 1 & 0 & 0 & 0 & 0 \\
\hline NYT39 & 0 & 0 & 0 & 0 & 0 & 0 \\
\hline NYT40 & 0 & 0 & 0 & 0 & 1 & 0 \\
\hline NYT41 & 0 & 1 & 0 & 0 & 0 & 0 \\
\hline NYT43 & 0 & 1 & 0 & 0 & 0 & 0 \\
\hline NYT44 & 0 & 1 & 0 & 0 & 0 & 0 \\
\hline NYT45 & 0 & 1 & 0 & 1 & 0 & 0 \\
\hline
\end{tabular}


NEWS FRAMING OF UNIVERSAL PRE-K ROLLOUT IN NYC

\begin{tabular}{|l|r|r|r|r|r|r|}
\hline NYT46 & 0 & 0 & 0 & 0 & 0 & 0 \\
\hline NYT47 & 0 & 1 & 0 & 0 & 0 & 0 \\
\hline NYT49 & 0 & 0 & 0 & 1 & 0 & 0 \\
\hline NYT50 & 0 & 0 & 0 & 1 & 0 & 0 \\
\hline NYT51 & 0 & 0 & 0 & 0 & 0 & 0 \\
\hline NYT53 & 0 & 1 & 0 & 0 & 0 & 0 \\
\hline NYT54 & 0 & 0 & 0 & 1 & 0 & 0 \\
\hline NYT55 & 0 & 0 & 0 & 0 & 0 & 0 \\
\hline NYT56 & 0 & 0 & 0 & 1 & 0 & 0 \\
\hline NYT57 & 0 & 1 & 0 & 1 & 0 & 0 \\
\hline NYT58 & 0 & 0 & 0 & 0 & 0 & 0 \\
\hline NYT60 & 1 & 1 & 0 & 0 & 0 & 0 \\
\hline NYT63 & 3 & 14 & 2 & 24 & 0 & 0 \\
\hline Total & 6.12 & 28.57 & 4.08 & 48.97 & 16.32 & 2.04 \\
\hline Percent & & & & & & 0 \\
\hline
\end{tabular}

\section{WNYC}

\begin{tabular}{|c|c|c|c|c|c|c|}
\hline Identifier & Responsibility & $\begin{array}{l}\text { Human } \\
\text { interest }\end{array}$ & Morality & Conflict & $\begin{array}{l}\begin{array}{l}\text { Economic } \\
\text { consequence }\end{array} \\
\end{array}$ & $\begin{array}{l}\text { Failing } \\
\text { schools? }\end{array}$ \\
\hline WNYC01 & 0 & 0 & 1 & 0 & 1 & 0 \\
\hline WNYC02 & 0 & 0 & 0 & 0 & 1 & 0 \\
\hline WNYC03 & 0 & 0 & 0 & 0 & 1 & 0 \\
\hline WNYC04 & 1 & 0 & 0 & 1 & 1 & 1 \\
\hline WNYC05 & 0 & 1 & 1 & 0 & 0 & 0 \\
\hline WNYC06 & 0 & 0 & 0 & 1 & 1 & 1 \\
\hline WNYC07 & 0 & 0 & 0 & 0 & 1 & 1 \\
\hline WNYC08 & 0 & 1 & 0 & 0 & 0 & 0 \\
\hline WNYC09 & 0 & 0 & 0 & 1 & 1 & 0 \\
\hline WNYC10 & 0 & 1 & 0 & 0 & 1 & 0 \\
\hline WNYC11 & 0 & 0 & 1 & 0 & 1 & 0 \\
\hline WNYC12 & 0 & 0 & 0 & 1 & 1 & 1 \\
\hline WNYC13 & 0 & 0 & 0 & 1 & 1 & 0 \\
\hline WNYC14 & 0 & 0 & 0 & 1 & 1 & 0 \\
\hline WNYC15 & 0 & 1 & 0 & 0 & 0 & 0 \\
\hline WNYC16 & 0 & 0 & 0 & 0 & 1 & 0 \\
\hline WNYC17 & 0 & 0 & 0 & 0 & 1 & 0 \\
\hline WNYC18 & 0 & 0 & 0 & 0 & 0 & 0 \\
\hline WNYC19 & 0 & 0 & 0 & 0 & 0 & 0 \\
\hline WNYC20 & 0 & 0 & 0 & 1 & 0 & 0 \\
\hline
\end{tabular}


NEWS FRAMING OF UNIVERSAL PRE-K ROLLOUT IN NYC

\begin{tabular}{|c|c|c|c|c|c|c|}
\hline WNYC21 & 0 & 1 & 0 & 0 & 0 & 0 \\
\hline WNYC22 & 1 & 0 & 0 & 0 & 0 & 0 \\
\hline WNYC23 & 1 & 0 & 0 & 0 & 0 & 1 \\
\hline WNYC24 & 0 & 0 & 0 & 0 & 0 & 0 \\
\hline WNYC25 & 0 & 0 & 0 & 0 & 0 & 0 \\
\hline WNYC26 & 0 & 0 & 0 & 0 & 0 & 0 \\
\hline WNYC27 & 0 & 0 & 0 & 0 & 0 & 0 \\
\hline WNYC28 & 1 & 0 & 0 & 0 & 0 & 0 \\
\hline WNYC29 & 1 & 0 & 0 & 0 & 0 & 0 \\
\hline WNYC30 & 1 & 0 & 0 & 0 & 0 & 0 \\
\hline WNYC31 & 0 & 0 & 0 & 0 & 0 & 0 \\
\hline WNYC32 & 0 & 0 & 0 & 1 & 0 & 0 \\
\hline WNYC33 & 0 & 0 & 0 & 0 & 0 & 0 \\
\hline WNYC34 & 0 & 0 & 0 & 0 & 0 & 0 \\
\hline WNYC35 & 0 & 0 & 0 & 0 & 0 & 0 \\
\hline WNYC36 & 0 & 1 & 0 & 0 & 0 & 0 \\
\hline WNYC37 & 0 & 1 & 0 & 0 & 1 & 0 \\
\hline WNYC38 & 0 & 0 & 1 & 0 & 1 & 0 \\
\hline WNYC39 & 0 & 1 & 0 & 0 & 0 & 0 \\
\hline WNYC40 & 0 & 0 & 0 & 0 & 0 & 0 \\
\hline WNYC41 & 1 & 1 & 0 & 0 & 0 & 0 \\
\hline WNYC42 & 1 & 0 & 0 & 0 & 0 & 0 \\
\hline WNYC43 & 1 & 0 & 0 & 1 & 0 & 0 \\
\hline WNYC44 & 1 & 1 & 0 & 0 & 0 & 0 \\
\hline WNYC45 & 1 & 0 & 0 & 0 & 0 & 0 \\
\hline WNYC46 & 0 & 0 & 0 & 0 & 0 & 0 \\
\hline WNYC47 & 1 & 1 & 0 & 1 & 0 & 0 \\
\hline WNYC48 & 0 & 1 & 1 & 0 & 0 & 0 \\
\hline WNYC49 & 0 & 1 & 0 & 0 & 0 & 0 \\
\hline WNYC50 & 0 & 0 & 0 & 0 & 0 & 0 \\
\hline WNYC51 & 0 & 1 & 0 & 0 & 0 & 0 \\
\hline WNYC52 & 0 & 0 & 0 & 0 & 0 & 0 \\
\hline WNYC53 & 0 & 0 & 0 & 0 & 0 & 0 \\
\hline WNYC54 & 0 & 0 & 0 & 0 & 0 & 0 \\
\hline WNYC55 & 1 & 1 & 0 & 0 & 1 & 0 \\
\hline WNYC56 & 0 & 0 & 0 & 0 & 0 & 0 \\
\hline WNYC57 & 0 & 0 & 0 & 0 & 0 & 0 \\
\hline WNYC58 & 0 & 1 & 0 & 0 & 0 & 0 \\
\hline WNYC59 & 1 & 0 & 0 & 0 & 0 & 1 \\
\hline
\end{tabular}


NEWS FRAMING OF UNIVERSAL PRE-K ROLLOUT IN NYC

\begin{tabular}{|l|r|r|r|r|r|r|}
\hline WNYC60 & 0 & 0 & 0 & 0 & 1 & 0 \\
\hline WNYC61 & 1 & 0 & 0 & 0 & 0 & 0 \\
\hline WNYC62 & 0 & 1 & 0 & 0 & 0 & 0 \\
\hline Total & 15 & 17 & 5 & 10 & 18 & 6 \\
\hline Percent & 24.19 & 27.41 & 8.06 & 16.12 & 29.03 & 9.67 \\
\hline
\end{tabular}


NEWS FRAMING OF UNIVERSAL PRE-K ROLLOUT IN NYC

\section{Appendix I - Spreadsheets}

\section{Sources Breakdown by Media Outlet}

\begin{tabular}{|l|r|r|r|r|}
\hline Category & Chalkbeat & New York Times & WNYC & \multicolumn{1}{l|}{ Total } \\
\hline NYC official & 22.75 & 29.41 & 23.39 & 25.35 \\
\hline state official & 8.47 & 12.75 & 7.6 & 9.75 \\
\hline other government official & 0 & 3.43 & 1.17 & 1.6 \\
\hline NYC education official & 14.29 & 3.43 & 15.79 & 10.82 \\
\hline other education official & 6.35 & 0.49 & 3.51 & 3.37 \\
\hline principal/administrator & 13.76 & 10.78 & 12.28 & 12.23 \\
\hline classroom teacher & 7.94 & 3.43 & 8.19 & 6.38 \\
\hline student & 1.06 & 1.47 & 5.85 & 2.66 \\
\hline parent & 4.76 & 6.37 & 7.02 & 6.03 \\
\hline teachers union & 2.65 & 2.45 & 0.58 & 1.95 \\
\hline advocacy organization & 6.88 & 9.31 & 5.85 & 7.45 \\
\hline think tank & 1.59 & 0.98 & & 0.89 \\
\hline $\begin{array}{l}\text { academic/institutionally } \\
\text { affiliated researcher }\end{array}$ & 1.59 & 4.9 & 2.92 & 3.19 \\
\hline other & 7.94 & 10.78 & 5.84 & 8.34 \\
\hline
\end{tabular}

\section{Generic News Frames by Media Outlet}

\begin{tabular}{|l|r|r|r|r|r|r|}
\hline & \multicolumn{1}{|l|}{ Responsibility } & \multicolumn{1}{l|}{$\begin{array}{l}\text { Human } \\
\text { interest }\end{array}$} & \multicolumn{1}{l|}{ Morality } & \multicolumn{1}{l|}{ Conflict } & $\begin{array}{l}\text { Economic } \\
\text { consequence }\end{array}$ & $\begin{array}{l}\text { Failing } \\
\text { schools? }\end{array}$ \\
\hline Chalkbeat & 11.94 & 19.40 & 7.46 & 38.80 & 8.95 & 4.47 \\
\hline WNYC & 24.19 & 27.41 & 8.06 & 16.12 & 29.03 & 9.67 \\
\hline NYT & 6.12 & 28.57 & 4.08 & 48.97 & 16.32 & 2.04 \\
\hline Total & 14.08 & 25.13 & 6.53 & 34.63 & 18.10 & 5.39 \\
\hline
\end{tabular}

